CARMEN BEATRIZ RODRIGUES FABRIANI

\title{
CULTURA DE SEGURANÇA VERSUS CULTURA DE RISCO: ESTUDO PSICOSSOCIAL SOBRE O OLHAR E A POSSIBILIDADE DE CAPTAÇÃO DE INFORMAÇÕES AMBIENTAIS
}

INSTITUTO DE PSICOLOGIA DA UNIVERSIDADE DE SÃO PAULO

São Paulo - 2004 


\section{CARMEN BEATRIZ RODRIGUES FABRIANI}

\section{CULTURA DE SEGURANÇA VERSUS CULTURA DE RISCO: ESTUDO PSICOSSOCIAL SOBRE O OLHAR E A POSSIBILIDADE DE CAPTAÇÃO DE INFORMAÇÕES AMBIENTAIS}

Tese apresentada ao Instituto de Psicologia da Universidade de São Paulo, como parte dos requisitos para obtenção do título de Doutor em Psicologia.

Área de concentração: Psicologia Social e do Trabalho Orientadora: Prof. Dra. Eda Terezinha de Oliveira Tassara

São Paulo

2004 


\section{CULTURA DE SEGURANÇA VERSUS CULTURA DE RISCO: ESTUDO PSICOSSOCIAL SOBRE O OLHAR E A POSSIBILIDADE DE CAPTAÇÃO DE INFORMAÇÕES AMBIENTAIS}

\section{CARMEN BEATRIZ RODRIGUES FABRIANI}

BANCA EXAMINADORA:

Tese defendida e aprovada em : 
Dedico esta tese a minha mãe, Nair e à sua mãe, Cecy. Duas mulheres que, em diferentes épocas, foram corajosas e determinadas ao perseguir seus desejos, embora preservando a harmonia familiar. A vocês, onde quer que estejam, obrigado. 


\section{Agradecimentos}

À Professora Dra. Eda, por ter acreditado no meu projeto, mostrando-se sempre disponível e aberta a novos olhares e por sua disponibilidade na orientação segura e amena, que guiou-me no desenvolvimento deste trabalho.

Aos colegas do Lapsi, principalmente ao grupo da terça feira pelas sugestões, idéias e apoio.

À minha família, Ana Cecilia, Helen e Otto pelo auxílio na compilação dos dados e edição final, ao Carlos Henrique por seu apoio e estímulo, mesmo distante, à Beth pelo cuidado na revisão editorial do texto e pela amizade incondicional e ao Leon por sua paciência e tranqüilidade, se tornando um porto seguro.

Ao Prof. Samonetto e Prof ${ }^{a}$. Dra. Maria Helena da UNIFAE, por sua compreensão e apoio nos momentos em que precisei priorizar as exigências do projeto de tese.

E, a todos meus colegas e amigos, que ao longo destes anos foram contribuindo no meu percurso. 
SAMPA (Caetano Veloso 1978)

Alguma coisa acontece no meu coração Que só quando cruza a Ipiranga e a avenida São João É que quando eu cheguei por aqui eu nada entendi

Da dura poesia concreta de suas esquinas da deselegância discreta de tuas meninas ... Ainda não havia para mim Rita Lee a tua mais completa tradução ... Alguma coisa acontece no meu coração ... Que só quando cruza a Ipiranga e a avenida São João

Quando te encarei frente a frente Não vi o meu rosto ... Chamei de mau gosto o que vi, de mau gosto, mau gosto ... É que narciso acha feio o que não é espelho E a mente apavora o que ainda não é mesmo velho Nada do que não era antes quando não somos mutantes ... E foste um difícil começo, afasta o que não conheço E que vem de outro sonho feliz de cidade Aprende depressa a chamar-te de realidade ... Porque és o avesso do avesso ... Do povo oprimido nas filas, nas vilas, favelas ... Da força da grana que ergue e destrói coisas belas

Da feia fumaça que sobe apagando as estrelas

Eu vejo surgir teus poetas e campos e espaços Tuas oficinas de florestas, teus deuses da chuva ... Pan américas de áfricas utópicas, túmulo do samba

Mais possível novo quilombo de Zumbi E os novos baianos passeiam na tua graça ... e os novos baianos te podem curtir numa boa. 


\section{SUMÁRIO}

LISTA DE FIGURAS Ix

LISTA DE TABELAS $\quad \mathrm{x}$

RESUMO Xi Xi

$\begin{array}{ll}\text { ABSTRACT } & \text { Xii }\end{array}$

I. INTRODUÇÃO 1

1.1 Percurso 1

$\begin{array}{lll}1.2 & \text { Configuração do tema } & 7\end{array}$

II. REVISÃO DA PROBLEMÁTICA 12

2.1 Problemática do Risco 12

2.2 Problemática da Modernidade 16

2.3 Problemática da Psicologia Ambiental 19

III. METODOLOGIA 22

$3.1 \quad$ Objetivo da Pesquisa 22

3.2 Objeto de estudo 25

3.3 Apresentação do Campo de Pesquisa 26

3.4 Método de Coleta de dados 38

3.5 Método de Análise dos dados $\quad 41$

IV. APRESENTAÇÃO E DISCUSSÃO DOS RESULTADOS 46

4.1 Os sujeitos da pesquisa 46

4.2 Categorias de Análise 50

4.3 Análise dos Depoimentos 57

4.3.1 Família $1 \quad 57$

$\begin{array}{ll}\text { 4.3.2 Família } 2 & 72\end{array}$

$\begin{array}{ll}\text { 4.3.3 Família } 3 & 97\end{array}$

$\begin{array}{lr}\text { 4.3.4 Família } 4 & 113\end{array}$ 
4.3.5 Família 5

128

4.4 A Instalação do Paradoxo

139

V. CONSIDERAÇÕES FINAIS

ANEXO A: Descrição do processo de ocupação da cidade de

Campinas/SP

REFERÊNCIAS BIBLIOGRÁFICAS

158 


\section{LISTA DE FIGURAS ${ }^{1}$}

Figura no

Páginas

1. Mapa de localização da rua Prof ${ }^{a}$. Altimira de Souza Pinto 27

2. Vista aérea da inundação na rua Prof ${ }^{a}$. Altimira de Souza Pinto 29

3. Bacias Hidrográficas com localização do córrego São Quirino 32

4. Vista aérea do curso do córrego São Quirino 34

5. Simulação do curso da onda de inundação 35

6. Vista aérea da barragem galgada. Fazenda Santo André 36

7. Vista aérea da barragem rompida. Fazenda Leôncio 37

8. Vista aérea da residência de D. Neuza 59

9. Corpos das três vítimas aguardando retirada na madrugada do dia 61 $18 / 02 / 2003$

10. Vista aérea da inundação na rua Prof ${ }^{a}$. Altimira de Souza Pinto. 63

11. Vista da rua na madrugada de 18/02/03 77

12. Interior da residência com marcas da enchente 79

13. Vista interna do estado da residência, logo após as águas baixarem 82

14. Frente da residência de Raul com o portão fora do lugar no dia seguinte 85

15. Vista do entulho no córrego São Quirino no dia seguinte 92

16. Vista da residência da família 3 com as marcas da enchente 98

17. Vista da rua com o rescaldo da enchente sendo retirado 106

18. Salvamento de Sr. Luís no telhado de sua casa 115

19. Vista da residência de Sr. Luís no dia seguinte 121

20. Vista da rua em local próximo a casa de Eliane, no dia seguinte 133

21. Situação, em junho de 2004, de escoamento do córrego sob a linha férrea 142

22. Situação do entulho a montante da rua Altimira de Souza Pinto, em 2004

23. Situação, em junho de 2004, de assoreamento no córrego São Quirino 144

24. Localização do Parque Imperador na mancha urbana de Campinas 155

25. Mapa ilustrativo da Região Metropolitana de Campinas. 156

\footnotetext{
${ }^{1}$ Todas as fotos relativas a enchente, incluindo as residências, as barragens e a rua Prof ${ }^{\mathrm{a}}$. Altimira de Souza Pinto foram cedidas por Jorge Ferreira.
} 


\section{LISTA DE TABELAS}

Tabela $\mathbf{n}^{\circ}$

1. Situação legal das intervenções no córrego São Quirino

2. Perfil sócio econômico da Região Metropolitana de Campinas
Páginas

147

157 


\section{RESUMO}

Fabriani, C. B. R. Cultura de segurança versus cultura de risco: estudo psicossocial sobre o olhar e a possibilidade de captação de informações ambientais. São Paulo, 2004. Tese de doutorado. Instituto de Psicologia, Universidade de São Paulo.

Este estudo visa A compreensão as maneiras como as pessoas enfrentam as situações naturais ou sociais de ordem catastrófica, que as ameaçam com perdas significativas, podendo chegar a própria identidade psíquica, social e física. $\mathrm{O}$ fenômeno observável é a incomunicabilidade do risco traduzido pela inação operativa estratégica frente à situações ameaçadoras. A hipótese é que o indivíduo enfrenta o risco de uma forma não razoável. Neste percurso investigativo, optou-se por coletar os dados junto a uma comunidade de moradores que passaram de forma coletiva, em 17 de fevereiro de 2003, por uma inundação de ordem catastrófica e foram realizadas um conjunto de entrevistas semi abertas, direcionadas pela busca do sentido desta experiência. As

perguntas foram estruturadas em função da necessidade de esclarecimento da informação fornecida nas respostas anteriores. Pressupõe-se que esta incomunicabilidade da risco se situa no imbricado das esferas psíquica, sociais e lógicas, onde o raciocínio entra como um apêndice explicativo, mas não na construção do argumento. A análise do fato ameaçador não entra no argumento decisório do sujeito, ela se constitui em um apêndice. O método de análise do argumento é usado para analisar os dados coletados, visando demonstrar a exterioridade do argumento lógico, que é utilizado de forma não lógica. 


\begin{abstract}
Fabriani, C. B. R. Safety culture versus risk culture: A psychosocial study about the regard and its caption possibilities of environment information. São Paulo, 2004. . Philosophy Doctor Thesis. Psychology Institute, São Paulo University.

This study aims to make clear how people react to catastrophic natural or social events, which may represent significant losses to its social psychic or physical identity. The observable phenomenon is the noncommunicability of risk translated in strategic operation inaction in face of threatening situations. This study holds the hypothesis that an individual faces risk in a nonreasonable way. In this research, the data was collected in a neighborhood in which dwellers suffered a catastrophic flood on February 17, 2003. A number of semiopen interviews were conducted in order to find the meaning of this noncommunicability of risk. According to the answer to a given question, the next question was formulated seeking to clarify the information given. It was assumed that this noncommunicability of risk is placed in the intersection of the psychic, social and logic spheres, where rational thinking is an explanatory appendix but does not contribute to the argument. The analysis of the threatening fact is not part of the decision argument of the subject; it is an appendix to it. The argument analysis method was used in the data analysis in order to demonstrate externality of the logic argument, which is used in a nonlogic way.
\end{abstract}


Ficha Catalográfica preparada pelo Serviço de Biblioteca e Documentação do Instituto de Psicologia da USP

Fabriani, C. B. R.

Cultura de segurança versus cultura de risco: estudo psicossocial sobre o olhar e a possibilidade de captação de informações ambientais./ Carmen Beatriz Rodrigues Fabriani. - São Paulo: s.n., 2004. - 162p.

Tese (doutorado) - Instituto de Psicologia da Universidade de São Paulo. Departamento de Psicologia Social e do Trabalho.

Orientadora: Eda Terezinha de Oliveira Tassara.

1. Ambiente social 2. Risco 3. Psicologia social 4. Análise do discurso 5. Psicanálise I. Título. 


\section{INTRODUÇÃO}

Inicia-se este trabalho pela apresentação do percurso de vida e profissional que conduziu esta pesquisadora até o tema que pretende desenvolver, para em seguida configurar o tema segundo a centralidade da problemática, como inerente ao processo civilizatório que nos trouxe à modernidade, à urbanização e às disparidades sociais, psíquicas e de conhecimento, que caracteriza este momento atual da humanidade.

\subsection{Percurso.}

$\mathrm{O}$ século $\mathrm{XX}$ serviu de cenário para o processo de construção do Brasil moderno, urbano, industrial, e quem viveu este período pagou um preço muito alto por isto e às vezes até alto demais, pago com a própria vida já que nada mais havia para dar. Muitas obras falam da implantação deste Brasil moderno e o cenário onde está localizada a presente tese de doutorado é a vida urbana, considerada não apenas a forma de ocupação do espaço, mas também a vida cotidiana que se desenrola neste cenário. A vida urbana brasileira é plena de contradições refletidas nos dados estatísticos do IBGE, onde o moderno e o antigo interagem num diálogo que muitas vezes parece ser de surdos e mudos e a poesia de Caetano Veloso (1978), em Sampa, expressa este espanto mútuo entre dois universos chamados a conviver em um mesmo espaço. Percebe-se um descompasso entre o discurso dos grupos hegemônicos que determinam, ou querem determinar, a organização da interação nas cidades e aqueles que ouvem este discurso a partir de universos culturais absolutamente distintos. Descontinuidade, qualidade daquilo que não é contínuo, descontínuo, interrompido como o diálogo entre estes interlocutores com linguagens referidas a lógicas distintas de avaliação dos fenômenos. Em outra parte deste trabalho será abordada a idéia de Giddens (1991) sobre descontinuidade, como uma 
característica da modernidade embora com conotações mais amplas, mas preferiu-se correr o risco de uma certa imprecisão e já usar este termo nesta introdução para caracterizar esta situação, considerando que esta integra o fenômeno em questão. Continuando e um pouco mais adiante neste percurso, a continuação na implantação do modelo da acumulação capitalista propiciou um agravamento deste diálogo descontínuo pelo acirramento das contradições já alinhavadas de maneira poética por Caetano Veloso. Na "poesia concreta das esquinas" depara-se com o espanto do menino que esmola nos semáforos para carrões dirigidos por anônimos, atrás de janelas fechadas para o diferente. O morador das cidades no Brasil defronta-se, independente de classe social, com situações limite de toda natureza, como se tivéssemos construído nossas cidades de forma inconseqüente, alheios às leis de causalidades naturais e a natureza transformada interativamente pelo social abriga uma forma de viver violenta e ameaçadora. Ao habitante deste cenário seria muito bom o desenvolvimento de uma grande capacidade de avaliação do risco, tanto do ponto de vista da oportunidade como do perigo no sentido colocado por Giddens (1991), onde "viver no universo da alta modernidade, é viver em um ambiente de oportunidades e risco" onde a alta modernidade caracteriza-se por um sistema dirigido à dominação da natureza e à autogeração da historia. Mas será que o morador das cidades brasileiras, de maneira geral pode ser considerado este sujeito da modernidade?

Prosseguindo no percurso do entendimento desta realidade urbana que também pudesse instrumentalizar a intervenção, após a graduação em arquitetura na FAU/UFRJ, passei um ano na Harvard University estudando planejamento urbano e regional. Ao voltar para o Brasil, após um breve intervalo, ingressei na COPPE / UFRJ onde completei o mestrado em Planejamento Urbano e Regional, que na ocasião estava vinculado ao programa de engenharia de produção. Hoje, este programa de mestrado está no Instituto de Planejamento Urbano e Regional na Faculdade de Arquitetura e Urbanismo, na UFRJ. Após alguns anos de exercício do planejamento à luz da matriz cientificista, com uma revisão crítica sócio-histórica, que nem sempre podia estar refletida nos documentos de planejamento, pelo menos não na sua íntegra, dado o momento político da vida nacional, principalmente na Secretaria de Estado de Planejamento e Coordenação Geral do Rio de Janeiro SEPLAN / RJ e em seguida na FINEP, foi configurando-se o interesse pela 
compreensão dos fatores que motivavam os comportamentos muitas vezes incompreensíveis, à luz da lógica racional, deste morador das grandes cidades. Durante a maior parte deste período de intervenção como planejador urbano, vivíamos sob a ditadura militar que tinha como reflexos no aparato do estado a implantação da tecnoestrutura estatal ${ }^{1}$. Portanto, a intervenção sobre o urbano faziase segundo as diretrizes dos sucessivos Planos de Desenvolvimento Econômico e Social e, mais especificamente, sob a égide do BNH - Banco Nacional de Habitação, responsável pelas diretrizes de implantação da infra-estrutura urbana e habitação. Este poderoso órgão administrava grande soma de recursos das cadernetas de poupança direcionada para o financiamento da construção das cidades brasileiras, até sua extinção no governo Sarney. Portanto, durante décadas cruciais da construção do "Brasil moderno" caracterizado pela urbanização crescente de sua população e palco de grande movimentação migratória, toda esta construção do espaço urbano seguiu uma ação política planificada e centralizada em um cenário político autoritário. Esta era a intenção explícita, mas uma enorme massa dessa população urbana ficou à margem desta política, sem acesso ao financiamento da casa própria, estando abaixo do nível de renda mínimo necessário para ser incluída e, literalmente, espalhou-se nas margens da cidade planejada, concentrando-se nos morros, charcos, alagados e outros lugares a esmo, onde a vida cotidiana não regulada e planejada corria seu fluxo, determinada pelo possível. Ainda na faculdade de arquitetura percorríamos as favelas com um olhar curioso buscando reconhecer, naquela forma de ocupação, a espontaneidade da arquitetura brasileira, das diferenças regionais aí traduzidas em cores, arranjos de espaço, etc. A favela da Maré, no Rio de Janeiro, localizada na margem da ilha do Fundão onde está o campus da UFRJ - Universidade Federal do Rio de Janeiro, hoje é parte integrante do Complexo do Alemão, cortado pela Linha Vermelha, uma via expressa que tem sido cenário dos tiroteios das quadrilhas do crime organizado em confronto com a polícia. Mas, então, era nosso "laboratório de

\footnotetext{
1 Ianni e outros analistas deste momento da vida política do Brasil, assim caracterizam esta estrutura do poder apoiada em organizações burocráticas, com recursos do pensamento técnico cientifico. Devido a seus recursos técnicos científicos, organizatórios e institucionais, podem focalizar os problemas numa perspectiva de curto, médio e longo prazos, onde as razões desta tecnoestrutura podem divergir e sobrepor-se ao poder legislativo, mesmo no âmbito de uma "democracia representativa". Os tecnocratas desempenham a função de diagnóstico das necessidades, elaboração, implantação e avaliação dos planos e executivos da política governamental planificada, e no âmbito da tecnoestrutura se realiza o balanço crítico do que é desejável e possível, considerando a conciliação entre razões de disponibilidade de recursos e definição de prioridades.
} 
observação" e percorríamos a favela, com nossas câmeras fotográficas, buscando recolher a alma deste novo carioca com raízes nordestinas e recém chegado. Tudo o que fora excluído pela perspectiva cientificista do planejamento integrado do governo dos militares era recolhido por este grupo de professores, alunos, artistas, poetas com atitudes intelectuais que poderiam ser classificadas conforme Figueiredo (1991) em uma matriz vitalista naturista com foco no qualitativo, no indeterminado e no criativo. Em campos diversos do conhecimento, como da arquitetura, da geografia e das ciências sociais, buscava-se uma leitura do urbano, em oposição ao paradigma da razão expresso na cidade planejada, que seria o paradigma da vida, expresso na ocupação caótica da periferia. Ainda, em conformidade com esta classificação, o método adotado neste modelo era o da identificação com estes personagens para compreendê-los, freqüentando as rodas de samba, as gafieiras, as associações de moradores, os campos de pelada, e o movimento tropicália pode ser a tradução nas artes deste momento de oposição da vida nacional. Para esta pesquisadora, inserida neste movimento de busca da compreensão do fenômeno urbano, estas experiências evoluíram para a avaliação de políticas públicas com intervenção sobre o social e prosseguiram com a avaliação dos projetos de intervenção aplicados pela sociedade civil organizada nas ONGs - organizações não governamentais, o terceiro setor, então já com a incorporação do referencial da psicologia, após a conclusão da graduação em psicologia.

Neste percurso, duas experiências destacam-se como antecedentes na formulação desta investigação. A primeira caracteriza-se como uma situação natural de ordem catastrófica, quando em 1988 ocorre um sério deslizamento nas encostas da cidade de Petrópolis, município no estado do Rio de Janeiro, provocado pelas chuvas de verão, com trágicas conseqüências; 173 mortes e 7.660 desabrigados. Após um levantamento historiográfico, em jornais e documentos técnicos, verificou-se que este cenário é próprio da cidade por sua localização geográfica, condições climáticas e forma de ocupação do solo. Verificou-se, também, que estes desastres eram sistematicamente seguidos de ações de solidariedade às vítimas no curto prazo, por um clamor intenso por obras "faraônicas" no médio prazo e de um esquecimento/desconhecimento do problema no longo prazo. (Fabriani,-1989). Investigando o potencial de mobilização da população da cidade (sede do município) para enfrentar uma situação de desastre natural, constatou-se que esta população 
parecia agir no cotidiano, sem memória e sem perspectiva de futuro, incapaz de articular ações conjuntas preventivas, reparadoras e minimizadoras do efeito destes desastres naturais. Desta experiência a questão que se colocou de imediato referia-se às razões pelas quais um problema tão sério, que acarretava tantos danos materiais e morais à população, inclusive com tantas vítimas fatais, não era capaz de gerar uma política pública consistente, que orientasse os projetos de intervenção de longo alcance nos mais variados setores afetos à administração pública. Por outro lado, também não parecia ser capaz de mobilizar os moradores para empreenderem ações, coletivas ou individuais, no presente que alterassem as condições de risco no futuro. ${ }^{2}$ A segunda experiência caracteriza-se como uma situação social de ordem catastrófica e refere-se à epidemia da AIDS e ao desenvolvimento de projetos de informação, educação e comunicação dirigidos à prevenção da AIDS, e implantação de serviços de atendimento a portadores de HIV e seus familiares, deparando-me com situações contraditórias, segundo a lógica formal da ciência médica e dos conhecimentos da imunologia. Não poderia dizer que a contradição estava nos fatos, já que a linha de contaminação seguia inexoravelmente a das práticas sexuais ou de uso de seringas entre os usuários de drogas e assim por diante. A contradição estava no olhar daquelas esposas portadoras de HIV acompanhando maridos padecendo de AIDS, no olhar de pais acompanhando filhos adolescentes contaminados no primeiro relacionamento e ainda no olhar de mães portadoras com filhos recém-nascidos, também portadores que insistiram em engravidar mesmo "cientes" da enorme probabilidade de transmissão do vírus ao filho, principalmente em períodos ainda pré-AZT, quanto mais pré-coquetel. Parecia que alimentavam a "ilusão" de que os acontecimentos não seguiriam a lógica das probabilidades cientificamente calculadas $^{3}$. Enfim, situações limite de uma avaliação do risco onde se constata que as decisões seguem muitas vezes argumentos de uma outra "lógica" mais afim com os afetos, inspirada pelos desejos e mais longe dos fatos.

\footnotetext{
${ }^{2}$ Neste trabalho, foi realizada uma investigação com representantes de três segmentos da população; comunidade de moradores das áreas consideradas de risco, poder público municipal e associações de engenheiros e arquitetos responsáveis por soluções técnicas. Estes segmentos demonstraram uma incapacidade em articular soluções conjuntas e de sentirem-se parte do problema e da solução.

${ }^{3}$ Os casos aqui citados estão documentados em protocolos de atendimento e projetos de prevenção da AIDS desenvolvidos ao longo de 11 anos de atenção a AIDS, inicialmente como diretora de uma ONG dedicada a AIDS e em seguida como coordenadora de um projeto de extensão universitária envolvendo intervenção, pesquisa e orientação de alunos
} 
Estes dois relatos de experiências referem-se a situações onde parece haver uma contradição inerente no agir, onde o tempo passado, o tempo presente e o tempo futuro parecem ser universos estanques, sem intercomunicação, como se os atos efetivados em uma dimensão não tivessem antecedentes e nem desdobramentos nos próximos acontecimentos. Algumas questões podem ser levantadas para compreender este fenômeno, algumas explicações partem do pressuposto de que estas populações são ou estão mal informadas sobre os fatos pertinentes, entretanto, devemos considerar que em ambas as situações é significativo o acúmulo de conhecimento que, se ainda não chega a explicá-las inteiramente, pelo menos permite estabelecer claras relações de causalidade e desenvolver protocolos de ações preventivas. Deve-se ainda considerar que estas informações têm grande exposição na mídia falada e escrita, sendo de domínio público. As estratégias de difusão do conhecimento têm propiciado várias campanhas informativas que adotam diferentes linguagens com o objetivo explícito de atingir diferentes segmentos da população, sem entretanto serem bem sucedidas na prevenção nas situações de risco. Embora sempre se possa aperfeiçoar na adequação da linguagem ao interlocutor, acredita-se que as estratégias pessoais de avaliação de risco são relativamente imunes a estas campanhas de informação. Entretanto, a avaliação dos riscos inerente a estas situações parece evidenciar a coexistência de duas lógicas orientadoras das decisões tomadas por estes atores, uma da subjetividade e outra da objetividade, que novamente nos faz deparar com esta conversa que parece de surdos, entre estes interlocutores. Acredita-se que a questão de como aproximar estes discursos nos leva a buscar compreender a equação "lógica" presente de tomada de decisão feita pelo sujeito comum, sobre seu cotidiano. Acredita-se que a apresentação das opções sobre as quais as pessoas têm que decidir pode ser preconceituosa e discriminatória para com outros modos de pensar e de organizar a vida. A incapacidade demonstrada de avaliar riscos não é intrínseca nem inerente a um ou outro grupo, mas pode ser fruto de situações em que é sonegado às pessoas o conjunto de informações sobre o mundo pelo qual estão decidindo e assim preenchem as lacunas com falácias, mas também pode ser decorrente do próprio processo fechado onde não se abre um espaço de interlocução entre o passado e o presente, o que determina a impossibilidade de pensar sobre o futuro. 


\subsection{Configuração Do Tema}

Em 1992, realizou-se, no Rio de Janeiro, a Conferência das Nações Unidas sobre Meio Ambiente e Desenvolvimento (CNUMAD), também conhecida por ECO-92. Entre suas muitas e relevantes atividades, ficou aprovado um programa de ação, conhecido como Agenda 21. Este programa é baseado num documento de 40 capítulos, que constitui uma ousada e abrangente tentativa de promover, em escala planetária, um novo padrão de desenvolvimento conciliando métodos de proteção ambiental, justiça social e eficiência econômica. Trata-se de um documento consensual, para o qual contribuíram governos e instituições da sociedade civil de 179 países num processo preparatório que durou dois anos. Enfim, a Agenda 21 traduz em ações o conceito de desenvolvimento sustentável.

Do ponto de vista da Agenda 21, as situações de risco recebem uma atenção especial, ficando estabelecido em seu capítulo 7, item 57 a urgente necessidade de fazer frente à questão da prevenção e redução dos desastres provocados pelo homem e/ou dos desastres naturais. Fica também estabelecido que o objetivo prioritário a ser alcançado refere-se a capacitar todos os países, em especial os que apresentem propensão a desastres, a mitigar o impacto negativo dos desastres naturais e/ou provocados pelo homem sobre os assentamentos humanos, sobre as economias nacionais e sobre o meio ambiente. Ficam previstas três distintas áreas de atividade para este aspecto do programa, a saber: o desenvolvimento de uma "cultura da segurança", o planejamento pré-desastres e a reconstrução pós-desastres. O foco de preocupação do presente estudo recai principalmente, sobre o potencial de desenvolvimento de uma "cultura de segurança" e secundariamente sobre as possibilidades de implementação do planejamento "pré-desastre". Quanto ao desenvolvimento de uma cultura de segurança entre as muitas atividades previstas pela Agenda 21, ressalta-se a de:

Implementar campanhas de conscientização de âmbito nacional e local por meio de todos os meios disponíveis, traduzindo o conhecimento em informações facilmente compreensíveis pelo público em geral e pelas populações diretamente expostas a riscos;(cap7.60.b)

Quanto ao desenvolvimento de um planejamento pré-desastres entre as muitas atividades previstas, esta determinação de integrar o planejamento pré-desastres no planejamento dos assentamentos humanos e entre outros deve incluir: 
- Desenvolvimento de programas de treinamento para administradores de locais de emergência, organizações não-governamentais e grupos comunitários que incluam todos os aspectos relativos a mitigação de desastres, inclusive de busca e resgate em áreas urbanas, comunicações de emergência, técnicas de pronto alerta e planejamento pré-desastres; (cap.7.61.g)

- Desenvolvimento de procedimentos e práticas que possibilitem às comunidades locais receber informações sobre instalações ou situações perigosas em suas jurisdições e facilitem sua participação nos procedimentos e planos de pronto alerta, redução dos desastres e reação em casos de desastre; (cap.7.61.i)

Quanto aos meios de implementação estão, entre outros, previstos os seguintes:

- Desenvolvimento de recursos humanos e capacitação institucional e técnica; (cap.7.64.c)

- Os países em desenvolvimento devem empreender programas de treinamento que devem ser estendidos aos funcionários públicos e planejadores da área governamental e às organizações comunitárias e nãogovernamentais para considerar todos os aspectos da mitigação de desastres, como técnicas de pronto alerta, planejamento e construção pré-desastres e construção e reabilitação pós-desastres. (cap.7.72)

$\mathrm{O}$ entendimento sobre a cultura da segurança não deve restringir-se às questões ambientais stricto sensu, percebe-se a mesma dificuldade em outras áreas da organização humana onde esta "cultura da segurança" encontra dificuldade em se concretizar. Entre 1997 e 2000 como coordenadora de um projeto de extensão na Universidade São Francisco, em Itatiba/SP, foram desenvolvidas inúmeras iniciativas para a prevenção da epidemia de HIV entre vários segmentos da comunidade e entre eles foi desenvolvido um estudo sobre os fatores que influenciam a decisão de um portador em revelar sua condição. Neste trabalho (Fabriani, 2000), procurou-se estudar a correlação entre os aspectos emocionais pertinentes ao quadro biopsicossocial de portadores de HIV e a disposição destes sujeitos em revelar essa 
sua condição a familiares e demais pessoas do seu convívio. Apoiando-se na literatura, verifica-se que os indivíduos que conseguem manter uma vida social, afetiva e profissional ativa, apesar da condição de portador de HIV, apresentam menor freqüência de infeções oportunistas e demais intercorrências negativas. Podese considerar que esta melhor qualidade de vida relaciona-se, também, com uma maior aderência aos tratamentos, muitas vezes penosos e invasivos. Quanto à perspectiva de expansão da epidemia é importante também a revelação dessa informação, o quanto antes, ao círculo de relações, seja para antecipar o início do tratamento, seja para evitar a disseminação do vírus. Entretanto, verificou-se que os portadores de HIV têm, em geral, muita dificuldade em revelar esta informação para este círculo de relações, sendo que independente de sexo, a razão alegada com maior frequiência para não revelação da condição de portador é o medo de punição e por outro lado, a razão para revelar é a expectativa de recebimento de aceitação e companheirismo. Verificou-se, também, que um ano após o primeiro teste positivo, pelo menos metade dos portadores ainda não havia revelado esta informação. Os resultados deste trabalho apontam para a imposição de razões psicológicas para este comportamento sobre a lógica dos benefícios individuais e coletivos de um compartilhar de informações e experiências com a família e a sociedade. Nesta avaliação do risco entre o revelar e o não revelar, encontram-se elementos para supor que as razões subjetivas inerentes ao indivíduo se impõem ou pelo menos mantêm um diálogo permanente com as razões objetivas que poderiam motivar uma pronta revelação e busca de atendimento e apoio.

Portanto, conforme visto acima a implantação de uma cultura de segurança implica, entre outras, melhor compreensão dos fatores subjetivos que determinam as decisões a nível individual e que certamente passam pela avaliação subjetiva e objetiva dos risco, estando implicada nesta decisão a qualidade de vida que o sujeito considera boa, aceitável, viável ou enfim, como diz o ditado popular, gosto não se discute.

Considerando a importância dos fatores de ordem subjetiva na operacionalização de uma cultura de segurança, se impõe a necessidade da articulação da subjetividade com a formulação de políticas públicas, o que não tem sido usual. Uma contribuição importante no sentido desta articulação está contida na perspectiva oferecida por Giddens (1991) sobre a pós-modernidade, onde o viver na 
pós-modernidade é viver num ambiente de chance e risco, em um sistema sócioeconômico e cultural direcionado à dominação da natureza e à operacionalização de um franco controle do mundo natural e social. Este direcionamento no sentido do controle sobre o mundo natural já se manifestava nas culturas não modernas, através das idéias de destino e carma refletindo uma concepção de que os fatos da história não se sucediam aleatoriamente, mas segundo uma ordem desconhecida, porém existente. A operacionalização de uma cultura da segurança implica a idéia de que além dos acontecimentos futuros não serem tão aleatórios assim, também o conhecimento sobre as variáveis intervenientes em cada evento ou sucessão de eventos possibilita a criação de rotinas preventivas com relação à ocorrência de acontecimentos indesejáveis, ou de rotinas para mitigação dos efeitos e conseqüências dos acontecimentos. Prosseguindo no argumento, a busca incessante de conhecimento sobre este "mundo natural" vem gerando uma imensidão de informações que bombardeiam os indivíduos através dos meios de comunicação, sobre parâmetros de segurança com relação à prevenção e tratamento de doenças, tratamento de dejetos, preparação de alimentos, processos industriais, processos de cultivo, formas de dirigir veículos, de relacionar-se sexualmente, maneiras de educar os filhos, e com relação a quase todos os aspectos da vida humana em sociedade. Nesta lista de prescrições, muito sucinta considerando a abrangência destes parâmetros, apesar de virem apoiadas em informações objetivas sobre o mundo natural, tais como conhecimentos sobre estruturas e funcionamentos virais, sobre elementos e processos poluentes, destrutivos ou agressivos ao ser humano, estas prescrições se intrometem em meio aos hábitos mais íntimos do sujeito, suas formas de comer, beber, amar, ser amado, cuidar-se e cuidar dos seus. O sujeito pósmoderno em meio a este bombardeio de informações, freqüentemente conflitantes, é chamado a tomar decisões, todas importantíssimas para a sobrevivência do eu em um processo de avaliação constante de risco e de chances. Esta avaliação é pessoal e intransferível para a sobrevivência do eu biopsicossocial ${ }^{4}$, e depende da estrutura deste eu para hierarquizar e ordenar esta imensidão de informações de acordo com

\footnotetext{
${ }^{4}$ As manifestações culturais recentes trazem inúmeros exemplos deste conflito subjacente ao viver na modernidade, quando podemos citar desde clássicos com Admirável Mundo Novo, de Huxley, e 1984, de Orwell, quanto às produções cinematográficas com THX1138 e, recentemente, Minority Report. Em todas elas está em debate este deslocamento do processo decisório para um poder político maior capaz de conter todas as informações para o "bem viver" e tomar as decisões pelo sujeito que resulta em um eu alienado de si mesmo.
} 
seus valores e gostos pessoais, contidos naquilo que usualmente chamamos de sua subjetividade. Estudos e exemplos relatados por Giddens (1991) apontam que esta auditoria do sistema de informações quanto à sua autenticidade é apoiada numa rede de confiança entre pares ou dirigida a alguma fonte geradora de informações, e substitui um sistema pericial individual pela confiança e possibilita a recomposição de uma rotina cotidiana com aparente normalidade, alheia aos riscos permanentes a que estariam todos submetidos. Um habitante de uma casa em qualquer uma das cidades do mundo dito desenvolvido, ao abrir uma torneira e fazer usos da água, tem uma idéia da constância daquele bem sem precisar dar-se conta do enorme arcabouço tecnológico e financeiro para que aquele "simples" ato seja possível. Esta transferência para um outro nível de tomada de decisão sobre um elemento vital cria uma situação interessante, onde por um lado a conveniência deste ato se impõe associada a uma enorme perda de liberdade de decisão que este abrir da torneira impõe. A possibilidade de implantação de uma "cultura de segurança" está na articulação entre estes dois eixos, liberdade e risco, considerando o quanto da decisão sobre o cotidiano individual é transferido a uma instância política "superior" e ainda o quanto deste processo é consciente. Ou seja, ao transferir a tomada de decisão sobre seu cotidiano o sujeito pode ou não estar consciente desta transferência, podendo ocorrer um processo de reificação ${ }^{5}$ da realidade, quando o sujeito coloca-se numa posição de inferioridade frente a um universo de sábios, quase divindades, a quem é reconhecido o direito à tomada de decisão sobre seu cotidiano. Estes "sábios" congestionam os meios de comunicação com afirmações contraditórias, fruto de inúmeros estudos e análises estatísticas e probabilísticas que substituem os oráculos da Antigüidade clássica e se constituem em sistemas periciais arbitrários que escravizam o indivíduo, alienando-o do processo de tomada de decisão sobre o modo de viver a sua vida. (Giddens, 1991).

\footnotetext{
${ }^{5}$ Reificação conceito desenvolvido por Adorno e Hokheimer na Escola de Frankfurt, podendo significar uma naturalização do mundo social.
} 


\section{REVISÃO DA PROBLEMÁTICA:}

Neste capítulo pretende-se a apresentação dos principais conceitos teóricos que sustentam este debate sobre avaliação do risco como uma ponte de interlocução entre o presente e o futuro. Portanto, inicia-se pela problemática do risco buscando sua conceituação histórica e as várias possibilidades de avaliação do risco, seguida pela concepção de risco para a modernidade. Por fim, desenvolve-se as categorias da psicologia ambiental que delimitam este debate.

\subsection{Problemática Do Risco}

Como avaliar o risco ? Esta é uma questão de difícil resposta se é que ela existe. Entretanto, pode-se avançar um pouco mais nesta discussão abordando a noção de risco conforme desenvolvida por Lieber (2002). A partir de um certo momento na cultura ocidental, o drama toma lugar da tragédia e o acaso passa a ser tratado como ignorância, entendendo-se por isso o momento em que a humanidade passa a considerar que pode controlar o desenrolar dos acontecimentos, e portanto a idéia de tragédia regida por um destino imutável é ocupada pelo drama onde o conhecimento pode mudar o destino. Para Lieber (2002) este momento de passagem está representado na mitologia romana pelo culto a Janus, deus do começo, deus do portal ou da dupla face, capaz de olhar simultaneamente para o passado e o futuro. Neste mito estaria presente a percepção de que o entendimento das relações entre passado, presente e futuro poderia determinar o rumo das transformações. A compreensão das relações de causalidade irá, mais adiante no percurso da humanidade, manifestar-se na busca incessante de conhecimento sobre os fenômenos naturais com o objetivo de controlar seus desdobramentos. Essa idéia de controle é muito próxima à idéia de risco, pois arriscado é tudo aquilo sobre o qual não se tem controle. Conceituar risco é uma tarefa arriscada (Lieber, 2002), pois estaríamos no 
limiar do mito e da racionalidade, ou seja, prever o futuro é atribuição dos deuses ou da ciência, se é que existe uma oposição entre estes dois universos. Mas pode-se sempre pensar que existe uma questão de métodos distintos na abordagem do controle de eventos futuros entre estas duas concepções e a humanidade até à atualidade não resolveu e nem se sabe se poderá resolver este enigma. A etimologia do termo risco remonta ao século XII como associado à idéia de fatalidade e sorte até que encontram-se registros do termo no século XVI, associado a transações comerciais no direito marítimo. A palavra deu origem a outras derivações como o arriscar ou ousar, como no ditado "quem não arrisca não petisca". Em suma, risco pode ter tido sua origem associada a empreendimentos de grande porte em um contexto incerto para o sucesso, como a navegação ou a ocupação militar e adquiriu este sentido de perdas e ganhos simultâneos. (Lieber, 2002; Ferreira, 1992). Neste mundo de fortuna ou azar, a quantificação do risco, quanto se ganha e quanto se perde, passa a ser imperioso e para uma cultura que se funda no mito da racionalidade científica, torna-se premente a instrumentalização das escolhas racionais.

No século séc. XVII, a quantificação do risco torna-se possível quando Pascal (1623-1662) desenvolve o cálculo de probabilidades onde o presente seria uma continuidade do passado, desde que algumas condições fossem satisfeitas: todos os sujeitos envolvidos em uma determinada situação teriam pleno conhecimento sobre as regras que regulam a situação e todos estariam igualmente submetidos a elas. Pascal apresenta à humanidade a possibilidade de submeter o futuro imponderável, a exatas equações matemáticas que se constituem um método científico de previsão do futuro. No século XVIII, LaPlace (1749-1827) desenvolve estudos sobre a probabilidade de morte associada ao uso da vacina de varíola, ou seja, as possíveis perdas ou ganhos no presente decorrentes de um evento passado e no século XIX a idéia de risco associado a ganhos se manifesta como benefícios de um empreendimento. Este conjunto de tentativas de projeções sobre o futuro tem como pressuposto o determinismo das leis naturais, onde tanto o passado como o futuro seriam cognoscíveis, desde que todas as forças e condições inicias do universo fossem previamente conhecidas, como tais forças e condições são ignoradas, aplicam-se a este desejo de conhecer o futuro as leis da probabilidade. (Harré, 1967 apub Lieber). Pode-se ainda observar que o desenvolvimento da conceituação de 
risco na cultura ocidental tem dialogado com uma contradição inerente, onde por um lado uma corrente cientificista busca uma aproximação objetiva da realidade, contraposta ou complementada por uma corrente romântica que busca uma compreensão subjetiva da realidade, considerada como social e culturalmente construída. Na perspectiva subjetiva, teríamos uma apreciação qualitativa de futuro, entendida como uma rede de organização da humanidade interagindo sobre uma natureza não alheia a esta humanidade, podendo-se avaliar o risco de uma situação futura dentro da perspectiva do desejável, embora este desejável não seja homogêneo na percepção de indivíduos ou grupos de indivíduos com desejos e vontades distintos e muitas vezes antagônicos. Na perspectiva cientificista a natureza é concebida como uma ordem, com leis próprias e independentes da humanidade e que a precede, podendo-se avaliar o risco do futuro dentro de uma perspectiva positivista, onde a probabilidade de acontecimentos seria uma decorrência da aplicação das leis naturais e um futuro mais ou menos adverso seria, de certa forma, desprovido de intenções boas ou más da humanidade. Estes pontos de vistas estão extensamente desenvolvidos por Figueiredo, Santos e Lieber, sendo que estes dois últimos aprofundam o estudo das relações entre a concepção de risco e as diferentes organizações humanas, características de cada período. Acompanhando-se o uso do termo risco ao longo da história e relacionando-se este uso com o instrumental disponível para conhecimento e controle dos fenômenos naturais, Lieber ressalta que na pré-modernidade o risco teria uma conotação neutra, seguido na modernidade com uma conotação de perigo decorrente da ciência ter métodos para identificar os riscos e as variáveis determinantes para sua ocorrência, mas sem a possibilidade de alterar o desenrolar dos acontecimentos e, na pós-modernidade o risco adquire uma conotação moral, como um exercício de opção entre formas distintas de vida, considerando que a humanidade acredita ter condições de alterar o curso dos acontecimentos. Entretanto, há que se definir qual entendimento de realidade está subjacente a esta concepção de risco e quais sistemas teóricos de verificação desta realidade estão em uso ao se estabelecer uma dada correlação entre eventos. Lieber (2002) nos oferece uma tipologia do risco e suas implicações teóricas conforme as possibilidades de compreensão da realidade, conforme a seguir:

- Posição Realista, objetivista ou materialista que considera a realidade como constituída por estruturas reais e imutáveis, com existência independente do 
homem e que o precede. Esta posição segue como pressuposto epistemológico o positivismo, onde o observador externo é capaz de objetivamente apreender as leis naturais e tem como pressuposto lógico a demonstração matemática. A conceituação do risco, nesta perspectiva objetivista ou racionalista, segue o seguinte modelo:

- depende das possibilidade analíticas para, efetivamente, estabelecer uma relação objetiva e quantificável, traduzida em probabilidade de ocorrência de um evento e de quantificação da magnitude de sua consequiência - estatística clássica.

- o processo de decisão está condicionado por preferências e interesses das diferentes partes e por escolhas pessoais.

- a interpretação do risco segue o modelo da teoria da complexidade ${ }^{6}$.

- Posição nominalista, subjetivista ou relativista onde a realidade é compreendida como um mundo social feito pela nomeação dos objetos, passando a existir a partir dos objetos ou eventos serem nomeados pelos homens e adotando como pressuposto epistemológico um relativismo, antipositivista, na apreensão da realidade e tem como pressuposto lógico o estabelecimento da não contradição entre os argumentos. A conceituação do risco, nesta perspectiva subjetivista ou relativista segue o seguinte modelo:

- Evolução do paradigma através da construção social do perigo com situações ou experiências nomeadas tais como: sujo igual a mal, limpo igual a puro e a construção de tabus como um sistema de ordenação e de exclusão do diferente.

- risco tratado como uma construção coletiva.

- Posição construtivista, teoria cultural do risco

\footnotetext{
${ }^{6}$ a) doutrina do empirismo onde a mente é suprida com material bruto através da percepção. Com a imaginação e o pensamento, pode-se construir novas idéias, apenas através da recombinação dos elementos dados. Estas novas idéias são portanto complexas, em oposição aos elementos básicos que são idéias simples. (Blackburn 1996) ; b) Edgar Morin, 81, filósofo francês e pesquisador da cultura, desenvolve a teoria da complexidade a partir de uma concepção particular sobre o termo "cultura". Do ponto de vista antropológico, é a carga de aprendizado que as pessoas acumulam, por meio de uma instituição ou não, e que produz complexidade individual e dá sentido à vida. Se vista de maneira histórico-social, cultura é aquilo que define cada sociedade, tais como: mitos, virtudes, valores, e linguagem, e nesse sentido, tem papel fundamental na organização social.
} 
- Perspectiva Fenomenológica Hermenêutica, onde o entendimento circunstancial que é dado ao risco é segundo a percepção do mundo a partir do senso comum e do conhecimento.

- Perspectiva Psicanalítica - como é construída a idéia de objeto decorrente da relação de estranhamento entre o sujeito e o outro - subjetividade, autonomia, aversão e fascínio.

- Perspectiva Estruturalista - conhecimento risco e prática estabelecido pelas estruturas culturais - manutenção do status quo, controle do desviante pelo uso das normas e regulamentos.

- Perspectiva Pós-Estruturalista - conhecimento e poder vinculados na construção do discurso sobre a realidade.

Em suma, esta tipologia oferecida por Lieber coloca em um gradiente duas posições que levadas ao extremo polarizam a compreensão do risco, sendo em um extremo como decorrente de leis naturais, totalmente independentes do observador, só restando a este conhecer estas leis. No outro extremo situa-se o risco como um conceito dependente da interpretação do observador de uma realidade socialmente construída. $\mathrm{Na}$ atualidade ambas as concepções coexistem em diferentes áreas do conhecimento e privilegiam uma ou outra concepção.

\subsection{Problemática Da Modernidade}

É interessante observar que Giddens (1991) colabora nesta discussão propondo uma perspectiva um pouco distinta ao considerar que a possibilidade de avaliação do risco é a condição de inserção na pós-modernidade e que estamos, ainda, mergulhados na modernidade, com esta capacidade reprimida por fatores de ordem subjetiva e objetiva. Acredita-se que este seja um dos pontos-chave desta questão e onde a psicologia pode vir a contribuir com seus paradigmas para a compreensão sobre o indivíduo e suas motivações individuais, porém socialmente construídas. Por modernidade Giddens está referindo-se aos estilos de vida ou organização social que emergiram na Europa a partir do séc. XVII e se globalizaram, perguntando-se se estamos chegando ao fim desta era com a emergência de um novo tipo de sistema social, como a sociedade de consumo e da informação ou se nosso tempo refere-se ao encerramento de um estado de coisas, o que chama de pós- 
modernidade. Este debate proposto por Giddens (1991) centra-se em torno de dois aspectos:

- transformações institucionais: deslocamento de um sistema baseado na manufatura de bens materiais, para outro relacionado centralmente com a informação;

- questões filosóficas/epistemológicas: conforme proposto por Jean-François Lyotard (apub Guiddens. 1991), a pós-modernidade refere-se a um deslocamento das tentativas de fundamentar a epistemologia e a fé no progresso planejado humanamente.

Nesse sentido, a pós-modernidade é caracterizada pela evaporação do enredonarrativa dominante, onde nos encontramos inseridos na história como seres tendo um passado definitivo e um futuro previsível. Já na perspectiva pós-moderna é percebida uma pluralidade de reivindicações heterogêneas de conhecimento, onde a ciência não tem uma posição privilegiada. Habermas, J. (apub Giddens) coloca a possibilidade de promover um conhecimento generalizável sobre a vida social e o estabelecimento de padrões de desenvolvimento social pela inclusão do conhecimento não formal. Ainda para Giddens, estamos alcançando um período em que as conseqüências da modernidade estão se radicalizando e universalizando em uma nova ordem pós-moderna, que se caracteriza por uma interpretação descontinuista do desenvolvimento social moderno, onde as instituições sociais modernas são únicas e diferentes da ordem tradicional e onde para sua compreensão deve-se capturar a natureza da descontinuidade. Somente esta análise poderá definir a natureza da ordem pós-moderna que deverá emergir ao final da era atual.

A modernidade é caracterizada por "descontinuidades" identificadas nos modos de vida por ela produzidos, que nos desvencilharam do modo tradicional pela "extencionalidade" e "intencionalidade". A primeira, caracterizada por formas de interconexão social global e a segunda, por formas da existência cotidiana, íntimas e pessoais. Entretanto, a percepção da descontinuidade fica impedida por teorias correntes como as teorias evolucionárias, que representam as grandes narrativas que compõem a história e impõem uma imagem ordenada sobre a mixórdia dos acontecimentos humanos. Portanto, para a compreensão da modernidade torna-se necessário desconstruir este enredo do evolucionismo social, significando que a história não pode ser vista como uma unidade ou como refletindo certos princípios 
unificadores de organização e de transformação, mas também que não pode ser vista como o império do caos, de forma idiossincrática com inúmeras narrativas sem ordem de hierarquização. Deve-se considerar que existem episódios de transição histórica a serem identificados que permitem a generalização. Estes indicadores de descontinuidade referem-se ao rítmo e escopo da mudança, onde os fatos integram uma rede de interconexão traduzida em ondas de transformação social globalizadas e por fim, à natureza intrínseca das instituições modernas, caracterizadas pelo sistema político de estado/nação, pela dependência da produção de fontes de energia inanimadas, e pela completa transformação em mercadoria, de produtos e trabalho assalariado. Avançando nesta caracterização da modernidade, sua natureza está polarizada no binômio segurança $\mathrm{x}$ perigo e confiança $\mathrm{x}$ risco, na medida em que vivemos um tempo marcado por estas duas dimensões. A primeira dimensão são as oportunidades de gozo de uma existência segura e gratificante, únicas e com benefícios que suplantariam as características negativas conforme apontado pela sociologia clássica, seja em Marx, onde a luta de classes seria uma fonte de dissidências fundamentais na ordem capitalista possibilitando a emergência de um sistema social mais humano, ou em Durkheim, onde a expansão do industrialismo possibilitaria uma vida social harmoniosa integrada através da combinação da divisão do trabalho e do individualismo ou por fim, em Weber, quando viveríamos o paradoxo do progresso material decorrente do avanço da burocracia mas que esmaga a criatividade e sufoca a autonomia individual. A segunda dimensão são as possibilidades de destruição em larga escala, seja do meio ambiente material que leva à gradual destruição da humanidade, seja da organização política estado/nação, que potencializa o depotismo em totalitarismo ao combinar poder político, militar e ideológico de forma mais concentrada, devido à própria característica da extencionalidade - formas de interconexão social global e devido à industrialização da guerra, decorrente da conexão da organização e inovação industrial com o poder militar, gerando o armamento nuclear que possibilita a total destruição da humanidade. Este mundo carregado e perigoso provoca a perda da crença no progresso, o que fundamenta a dissolução da narrativa da história.

Entretanto, viver neste mundo onde o sentido coletivo fica assim desconstruído, pode ser extremamente angustiante. Sem as grandes utopias que deram sentido, até recentemente, ao viver, fica uma ausência a ser preenchida. A 
ciência formal e os especialistas, de certa forma, ocupam este vazio e produzem a todo momento propostas de como prolongar a vida, de como evitar os riscos das doenças ou do envelhecimento, entretanto estas propostas também são rapidamente superadas e substituídas e acaba que o indivíduo muitas vezes terá que, frente à controvérsia, fazer escolhas que definem seu estilo de vida e que nestas decisões concepções de sorte, fatalismo, pragmatismo e avaliação consciente de risco estão presentes. (Giddens, 1991)

\subsection{Problemática da Psicologia Ambiental}

A psicologia ambiental caracteriza-se por ser uma área ainda recente onde ainda há um certo debate em termos de objeto de estudo e de metodologia, conforme pode ser verificado entre os muitos trabalhos apresentados no Simpósio Internacional em Psicologia Ambiental promovido pelo Laboratório de Psicologia Sócio Ambiental e Intervenção e o Instituto de Psicologia Social Lapsi/ Iaps, realizado na Universidade de São Paulo/USP, em 2002. No entanto, pode se considerar que a área fica definida como o estudo das relações entre a pessoa e o ambiente através da descrição do contexto ambiente, vinculado às condições sócioeconômicas, territoriais e políticas, onde as pessoas desenvolvem um certo estilo de viver. Nesse sentido, caracteriza-se pela transdisciplinaridade ${ }^{7}$ com a arquitetura, a sociologia, a política e a ecologia e destaca-se da ciência ambiental entendida como conservação da natureza. Conforme Tassara (2002), dentro da perspectiva das ciências da natureza, o ambiente deve ser entendido como "espaço total", terminologia adotada por Santos, representando a história da ocupação humana no espaço e as transformações aí impetradas, no sentido da conservação da vida numa perspectiva que desnaturaliza o ambiente e o percebe como o espaço das relações humanas. Tassara (2002) propõe no paradigma da Ciência Ambiental Prospectiva a concepção de que ciência e política não poderiam estar separadas, sendo "constituída de sistemas dinâmicos de tecnologia, informações e juízos fundamentando decisões sobre o futuro construído do planeta, articulando a participação crescente de indivíduos, grupos, sociedades e humanidades, relacionando em seus projetos de conhecimento e intervenção ciência,

${ }^{7}$ Segundo Prado Junior, "Como o prefixo 'trans' indica, a transdisciplinaridade diz respeito ao que está, ao mesmo tempo, entre as disciplinas, através das diferentes disciplinas e além de todas as disciplinas. Seu objetivo é a compreensão do mundo presente, e um dos imperativos é a unidade do conhecimento." 
filosofia, história e política”. Nesta concepção, a contribuição da psicologia ambiental é de "estudar a concretude da experiência humana no ambiente para, desenvolvendo explicações sociologismo, propiciar, através de seus programas de investigação, conhecimentos sobre como se adapta o homem ao sistema-mundo e como este sistema-mundo se interioriza na subjetividade deste homem". Nesta perspectiva a compreensão sobre o urbano não seria domínio de nenhum campo do saber mas algo construído no que Habermas chama de "espaços de locução", nos quais ocorreria a desinstrumentalização dos preconceitos, possibilitando a participação efetiva do cidadão na construção do seu viver.

Com relação à participação, é necessário que se esclareçam as condições para que a participação possa ser a mais efetiva possível. Para participar no processo decisório sobre o seu espaço real de vida é necessário que o indivíduo possa ter consciência das variáveis atuando naquele espaço, naquele momento, que processos originaram estas variáveis e qual o seu provável desenvolvimento. Somente assim o indivíduo pode ter uma ação estratégica, decidindo no presente formas de ocupação e de delineamento do espaço real onde estão sendo feitas a avaliação das condições de conservação da vida, que se projetarão no futuro. Nesse sentido, tratamos aqui de uma participação emancipatória conforme apresentado por Tassara \& Ardans (2004), como a ação de fazer parte de "processos de transformação social que suponham não uma passividade dos atores (convocados de cima e de fora, meros receptores das conseqüências das políticas públicas) mas, pelo contrário, uma ação enquanto agentes do processo em todas as suas fases e para todos os efeitos”. Assim, cabe ressaltar que o processo de avaliação e tomada de decisão é um processo racional onde o indivíduo tem acesso às causas da situação que está avaliando, tem conhecimento que o possibilite prever os desdobramentos de sua decisão e pode assim tomar sua decisão apoiado num processo lógico racional de pensamento. Entretanto, tal muitas vezes não acontece, na medida em que o indivíduo é chamado pelo poder público a participar nas decisões sem contudo participar na geração da informação. A informação produzida pelo poder público que legisla, vem carregada com esta ideologia o que tolda a lógica do processo na medida que os preconceitos estão presentes na construção das afirmações que comporão o argumento. A verdade produzida neste processo tem pés de barro e não é susceptível a crítica, e nesse 
sentido a construção da participação fica manca e não tem ação efetiva na construção do ser e do conviver. Segundo Tassara e Ardans (2004) o processo de participação deveria ser fruto de um pensamento racional sobre o espaço, mas é fruto de uma racionalização, conforme a seguir:

- "Racionalidade faz referência a processos lógicos e epistemológicos nos quais, a partir de determinadas premissas e pela via da argumentação, derivam-se conseqüências legítimas, do ponto de vista formal; a relação lógica implica que se for aceita uma afirmação estarão sendo aceitas as suas premissas. A racionalidade exige, precisamente, tornar transparente essa derivação lógica pela via argumentativa, o que torna possível a crítica, seja do ponto de vista formal ou seja do ponto de vista do conteúdo da afirmação em questão. Deste modo, crítica e racionalidade são componentes inseparáveis do mesmo processo epistemológico.

- Racionalização, por sua vez, refere-se a afirmações cujas premissas são desconhecidas ou deliberadamente escamoteadas, impedindo o conhecimento da argumentação (que leva da afirmação às suas premissas) e impossibilitando, por conseqüência, a crítica. "Verdades" cujo fundamento desconhecemos são ideologia, pois, ao serem apagadas as premissas, são as mesmas incorporadas como conhecimento estabelecido, absoluto, a-temporal, o que, entretanto, é ilegítimo, por desvincularmos a "verdade" de sua fundamentação lógica. Deste modo, o racionalismo ocidental pode ser entendido como o solapado trânsito da racionalidade à racionalização ou, talvez mais apropriadamente, como fazer passar racionalização por racionalidade, processo ideológico em que são dadas como verdades afirmações cuja origem foi deliberadamente escamoteada no processo de modernização".

Considera-se, assim, que estão lançadas as bases para a realização desta pesquisa sobre a avaliação de situações onde está implicado uma ameaça (risco) de alguma catástrofe ambiental pelos moradores da região. Deve-se enfocar como se dá este processo de avaliação e tomada de decisão, em particular a construção do argumento e, portanto, será dado prosseguimento à apresentação da metodologia proposta. 


\section{METODOLOGIA:}

Neste capítulo busca-se apresentar de forma mais clara os objetivos desta pesquisa, as determinações na escolha dos sujeitos e os procedimentos de coleta das informações, seguido de um debate sobre o método de análise dos dados.

\subsection{Objetivo da Pesquisa}

De maneira geral, busca-se respeitar a colocação de Habermas apub Bauer \& Gaskell, (2002) onde o que se pretende é que seja construído um conhecimento que possa oferecer a indivíduos capazes de falar e agir, as condições para que a experiência possa fundamentar uma objetividade. Nesse sentido, a metodologia deverá seguir a coleta de dados e não ao contrário, respeitando o que os dados nos trarão. Segundo Habermas, considera-se os três interesses constitutivos do conhecimento, primeiro o interesse pelo controle técnico, originário na luta permanente de controlar o mundo natural necessária à reprodução de nós mesmos e levando ao estabelecimento de normas que guiam nossas ações com propósito racional. O segundo seria o interesse prático da ciência no estabelecimento do consenso decorrente de uma compreensão intersubjetiva fidedigna estabelecida na prática da linguagem comum, (Bauer \& Gaskell. 2002). Esta compreensão hermenêutica implica a restauração de canais rompidos de comunicação no eixo experiência individual e tradição a que o sujeito pertence, e no eixo da intercomunicação entre indivíduos, grupos e tradições. Como a incomunicabilidade é uma característica perpétua do mundo social, consequentemente a preocupação em restabelecer o entendimento mútuo torna-se de tal modo um interesse perpétuo. Quanto ao terceiro interesse da ciência, é que seja possível o exercício da crítica que pode levar ao esclarecimento e ao conhecimento emancipado crítico que revelam as relações ideologicamente congeladas de dependência e que podem ser objeto de 
transformação. Neste sentido, seria através de um processo auto-reflexivo que as ciências críticas podem identificar as sutis estruturas de poder que resultam na naturalização e reificação da vida social. Neste estudo nos inspira o segundo e terceiro dos objetivos da ciência mencionados anteriormente.

De maneira específica, o objetivo desta pesquisa é compreender as maneiras como as pessoa enfrentam as situações naturais ou sociais, de ordem catastrófica, e que portanto, ameaçam a própria identidade com perdas significativas de ordem psíquica, social ou até física. Podería-se esperar que as pessoas dispusessem de um instrumental para avaliar o potencial de risco das situações e poderem assim definir estratégias lógicas de enfrentamento destas situações. Considerando a literatura abordada anteriormente, estes critérios se deslocariam num eixo subjetivo/objetivo onde no extremo do subjetivo ficariam os sonhos, aspirações e valores configurados na visão de mundo e que é resultado da interseção do universo cultural com o universo individual. Por outro lado, no extremo do objetivo ficariam as informações produzidas pelo conhecimento formal ou informal, que poderia informar sobre os possíveis e mais prováveis desdobramentos de cada situação, porém os critérios utilizados nesta avaliação não necessariamente seguem a lógica da argumentação. $\mathrm{Na}$ construção de um argumento podería-se levar em conta os antecedentes da situação, como por exemplo as séries históricas dos índices de chuva na região, a incidência de enchentes e alagamentos, os estudos hidrodinâmicos da calha dos rios e seu potencial de vazão por minuto ou, ainda, índices de absorção de água pelo solo cotejados com os coeficientes de impermeabilização do solo, por asfaltamento de ruas, construções, etc. Mas, parece que todas estas informações perpassam um universo paralelo ao da tomada de decisão e não se interceptam a não ser por breves momentos e sem provocar os efeitos esperados. Assim, como afirmam Tassara \& Ardans (2004) o argumento não representa a verdade, não tem origem na lógica e portanto não pode ser refutado ou aceito, é uma verdade quase que mítica para aquele sujeito. O indivíduo fica posicionado num espaço atemporal, já que não se apropria do passado e não tem bases para projetar o futuro, e tomará decisões de que ordem? Não pode pensar sobre o risco como uma probabilidade de algo vir a acontecer ou não e apenas no confronto com a concretude do fato é que sob impacto, decide algo, mas ainda assim sem entrar em contato com a corrente de argumentos logicamente construída. Fica-se com a idéia de que a decisão já está tomada a priori, é preconcebida a partir 
do universo simbólico do sujeito, de suas possibilidades culturais, sociais e subjetivas de criar soluções que se afastam do mundo "real". Veja a seguir, o depoimento de uma vítima de enchente sobre a decisão de continuar morando no mesmo local:

C: Certo. E o fato de saber depois, mudou a sua..., como é que é morar aqui agora, depois que tudo isso aconteceu?

S: A mesma coisa. Gosto daqui do mesmo jeito. Não tenho medo, já tem chovido bastante depois disso. Já enfrentamos chuva forte, nesse período de um ano, pra mim tudo bem, normal. Não tenho medo, não fico preocupada, nada, nada. Eu gosto daqui, apesar dos pesares, eu gosto daqui, gosto do lugar, acho aqui uma delícia.

Parece tratar-se de uma tentativa em conflito, de enquadramento do racional numa dimensão não racional, porém razoável. É como se o sujeito precisasse fazer uma concessão à sua identidade, aos seus antecedentes históricos e não aos do fato e nesse sentido, certas decisões são necessárias para que o sujeito continue ele mesmo. Esta linha de raciocínio nos coloca uma questão importante e central para a psicologia que seria a possibilidade da consciência e da prevalência do sujeito emancipado. Do ponto de vista psicanalítico, a negação do risco seria decorrente de uma perda na capacidade de aferir a realidade devido a uma fragilidade emocional do ego consciente racional em enfrentar a ameaça de aniquilamento do eu e portanto uma fuga para um mundo imaginário mais ameno. Entretanto, como do ponto de vista lógico a negação não existe e a negativa de uma afirmação é sua recusa, para um observador externo não envolvido, frente ao sujeito naquele universo cultural, social e emocional, pode-se configurar este particular processo de avaliação como razoável, mas não racional no sentido apresentado por Tassara \& Ardans (2004). Mas, o que fundamenta esta razoabilidade? Parece que o estudo junto a pessoas que viveram uma situação de risco e o recolhimento de sua história pessoal poderá nos esclarecer sobre estas premissas não explícitas do razoável, que têm uma configuração de ideologia, de "filosofia pessoal de vida". Parece que se está frente a um a situação peculiar, caracterizada pela coexistência de pelo menos dois complexos de premissas incomunicáveis, um lógico racional e outro lógico emocional. No processo de pensamento sobre o fato, a circunstância lógica parece que é um apêndice ao processo e que no máximo intervém, mas não de maneira 
decisiva. No caso estudado nesta pesquisa, as pessoas entrevistadas guardam relíquias do acontecido, rescaldos da enchente, quadros aparecidos que não vieram de lugar nenhum, vidros de esmalte cheios de barro e outros objetos, numa arqueologia paradoxal e coloca-se a perplexidade frente à incomunicabilidade operatória da ameaça externa ou interna que se remete à necessidade do desenvolvimento de uma leitura psicossocial do fenômeno.

\subsection{Objeto De Estudo}

$\mathrm{Na}$ construção do $\operatorname{corpus}^{8}$ da pesquisa buscou-se colecionar de maneira sistemática o relato de indivíduos sobre situações de risco pelo qual passaram e seus desdobramentos, como mudanças em suas atitudes, valores, opções de vida e outros aspectos que constituem o sentido da vida para estas pessoas. Certamente esta seleção dos elementos da pesquisa é arbitrária, embora se tenha buscado seguir a sugestão de Barthes (Bauer \& Gaskell. 2002 p..55) sobre os princípios da semiótica, com relação a relevância, homogeneidade e sincronicidade do material de estudo. Conforme a afirmação de Barthes, em que a seleção dos elementos é menos importante que a análise compreensiva, mas que não pode ser separada dela e ainda do cuidado que se deve tomar em analisar materiais homogêneos. Dessa maneira, o corpus será o texto dos depoimentos e o material de imagens anexado será considerado ilustrativo e destinado apenas à caracterização do campo onde os depoimentos foram recolhidos. Nesse sentido, o material do corpus tem apenas um foco temático - o estudo do relato da experiência de risco em que os depoentes estiveram envolvidos e foram colhidos num intervalo de tempo curto, de aproximadamente 60 dias e 13 meses após o ocorrido, buscando-se preservar a estabilidade, relevância e homogeneidade das informações. A coleta dos depoimentos cerca de um ano após o ocorrido contribui para uma maior clareza do sentido da experiência para aquelas pessoas. Por fim, deve-se considerar que ao optar pela coleta qualitativa de informações, a partir do discurso dos sujeitos da pesquisa, toma-se em conta as teorias da psicolingüística representadas pelos estudos de

${ }^{8}$ Corpora no sentido lingüistico são coleções de dados de linguagem que servem para vários tipos de pesquisa. O termo está ligado a desenvolvimento de estudos de linguagem em computador (Johansoson, 1995) . Corpus lingüistico é um material escrito ou falado sobre o qual se fundamenta uma análise lingüistica ( Oxford English Dictionary, 1989) . 
Chomski e Jakobson, onde o estudo dos estados psicológicos e atividade mental está associado com o uso da linguagem. A psicolingüística investiga as relações entre pensamento e linguagem e sustenta um debate permanente, sendo se a linguagem é decorrente do pensar ou o pensamento é decorrente do uso da linguagem.

\subsection{Apresentação do campo de pesquisa.}

O campo de pesquisa está delimitado no tempo e no espaço, quando foi escolhido centrar a investigação em um evento ocorrido em 17 de fevereiro de 2003, quando uma chuva de grande intensidade caiu sobre a cidade de Campinas no estado de São Paulo, com graves consequiências. A cidade tanto poderia chamar-se campinas ou colinas, pois o sítio onde Campinas se desenvolveu, caracteriza-se por uma sucessão de pequenas colinas, sempre com um riacho ou córrego no fundo dos vales, de cujas margens a ocupação urbana se espalhou pelas encostas suaves mas destruindo as matas ciliares e assoreando os cursos d'água. As pitorescas avenidas beirando os rios tornam-se traiçoeiras no período de chuvas, quando concentram os alagamentos que periodicamente vitimam seus moradores e passantes. Todos os anos os jornais mostram os carros arrastados pela forte correnteza, as casas alagadas e o desamparo dos desabrigados e desalojados. As vítimas nem sempre são a população de baixa renda moradora da periferia, as avenidas alagadas são eixos viários de importância e às vezes local de residência da classe média. Em Campinas, o verão caracteriza-se por ser uma estação de intensas chuvas e neste 17 de fevereiro de 2003 as inundações ocorreram principalmente em duas comunidades, uma rua com 33 casas de padrão médio/elevado que acompanha o córrego São Quirino (Figura 1.) e uma outra via com inúmeras casas de uma favela denominada Vila Moscou, que acompanha o córrego Anhumas, ambas próximas e em margens opostas da rodovia D. Pedro I que corta a cidade. Neste dia, considerando vítimas fatais, o caso mais grave aconteceu no Parque Imperador onde três pessoa da mesma família morreram afogadas e 33 famílias ficaram desabrigadas após as águas invadirem a rua marginal ao córrego que corta o bairro e atingirem a altura da cumeeira das casas. De acordo com a defesa civil, Campinas registrou neste dia seis pontos de alagamento que deixaram um saldo de 1.375 desabrigados e 1.444 desalojados. 
Figura 1 - Mapa de localização da Rua Prof ${ }^{a}$. Altimira de Souza Pinto

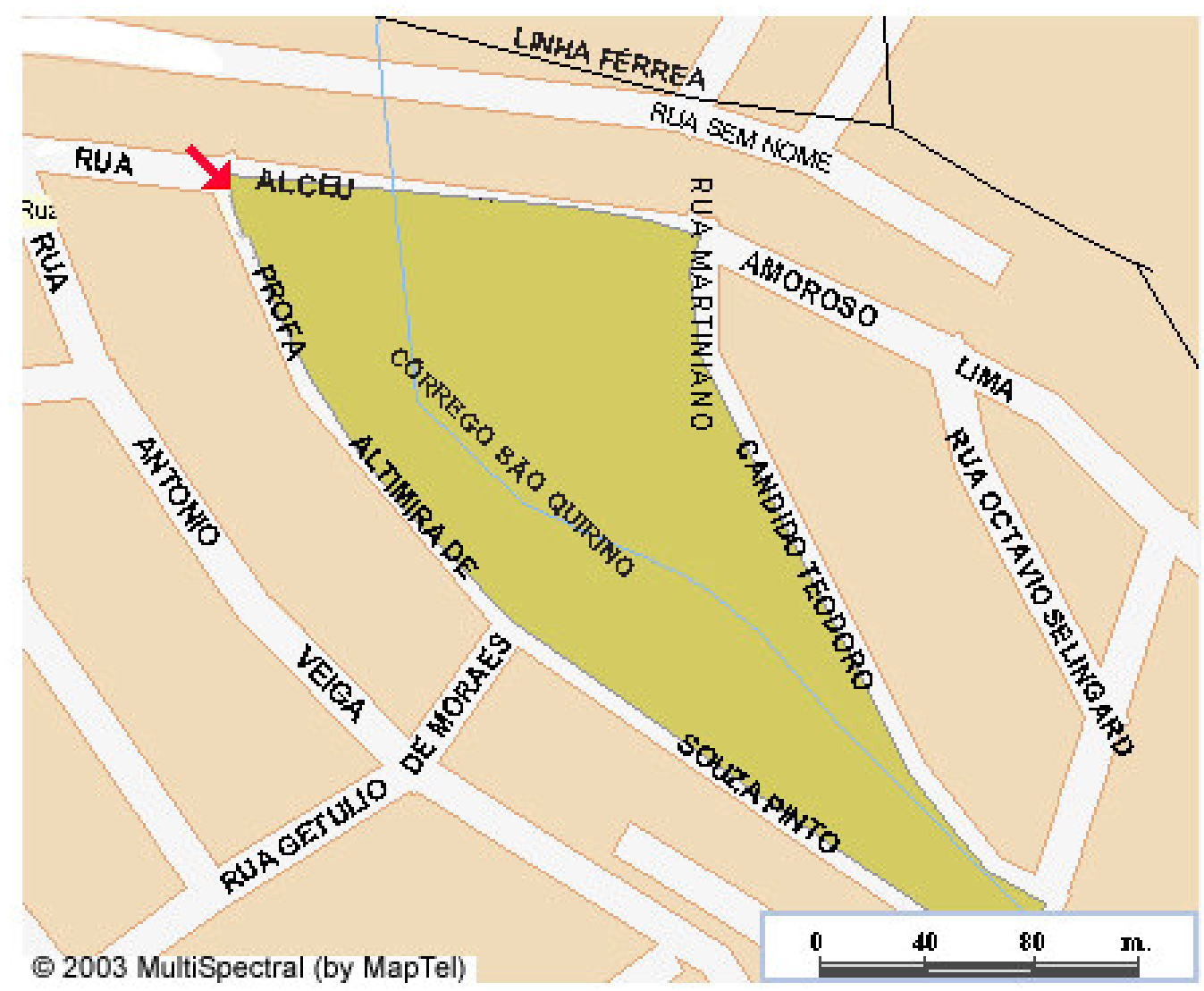


Segundo o Centro Integrado de Informações Agrometeorológicas de Campinas (IAC), foram registrados 115,5 milímetros acumulados de chuva em sete horas, o maior índice para o mês de fevereiro dos últimos 40 anos (Correio Popular 16/02/2004 p. 7 Cidades.). A imprensa local fez uma ampla cobertura do evento 9 relatando com cores trágicas este acontecimento, quando foram contabilizadas 650 pessoas desabrigadas e ficou decretado o estado de emergência pelo governo municipal. Após o balanço das vítimas quando ficou constatado que havia o saldo de 4 vítimas fatais (um bombeiro), 1 pessoa desaparecida, 650 desabrigados, 48 pontos de alagamento, 17 inundações, 40 casas com risco de desabamento, desabamento de 2 casas, 8 deslizamentos, 2 soterramentos, 164 ocorrências registradas pela defesa civil de Campinas, 22 apartamentos alagados pelo córrego Anhumas no bairro Jardim Flamboyant, 1 rompimento de açude e 300 pessoas desalojadas. Segundo o Diretor da COHAB na ocasião, “existem em Campinas 96 áreas públicas e privadas onde vivem 5 mil pessoas que estão sob permanente monitoramento devido a risco de alagamento, deslizamentos e de outros incidentes ${ }^{10}$, sendo que a região com maior número de famílias em situação de risco é a leste, onde se localizam a Rua Moscou e o Parque Imperador". Ele coloca ainda que existem alguns planos de remoção dos moradores dessas favelas, mas que muitos se recusam a ir para as casas nos conjuntos habitacionais. Devido às chuvas ocorreu, também, o transbordamento do Rio Atibaia o que interrompeu a captação de água pela Sociedade de Abastecimento de Água e Saneamento (SANASA) e causou desabastecimento em vários bairros chegando a comprometer $60 \%$ das áreas atendidas pela SANASA. Pelo menos 25 escolas e creches da rede municipal tiveram as aulas suspensas devido à inundação e à lama que obstruiu o acesso às mesmas. O Aeroporto Internacional de Viracopos ficou 14 horas interditado e a Empresa Municipal de Desenvolvimento (EMDEC) registrou 19 quilômetros de congestionamento. Com relação ao Parque Imperador, (figura 2) bairro onde se localiza o conjunto de moradores da mesma rua, entrevistados nesta pesquisa, talvez a forma mais esclarecedora de contar o ocorrido

\footnotetext{
${ }^{9}$ Foi feita uma ampla cobertura pelo jornal Correio Popular em suas edições dos dias 18, 19, 20, 21, 22 e 23 de fevereiro de 2003 no caderno Cidades cujo conteúdo estará sendo utilizado nesta descrição. ${ }^{10}$ Informações atribuídas ao diretor da Companhia de Habitação Popular de Campinas (Cohab) Sr. Miguel Jorge Nicolau Filho, conforme uma das reportagens mencionadas.
} 
Figura 2 - Vista aérea da inundação da rua Prof ${ }^{a}$. Altimira de Souza Pinto

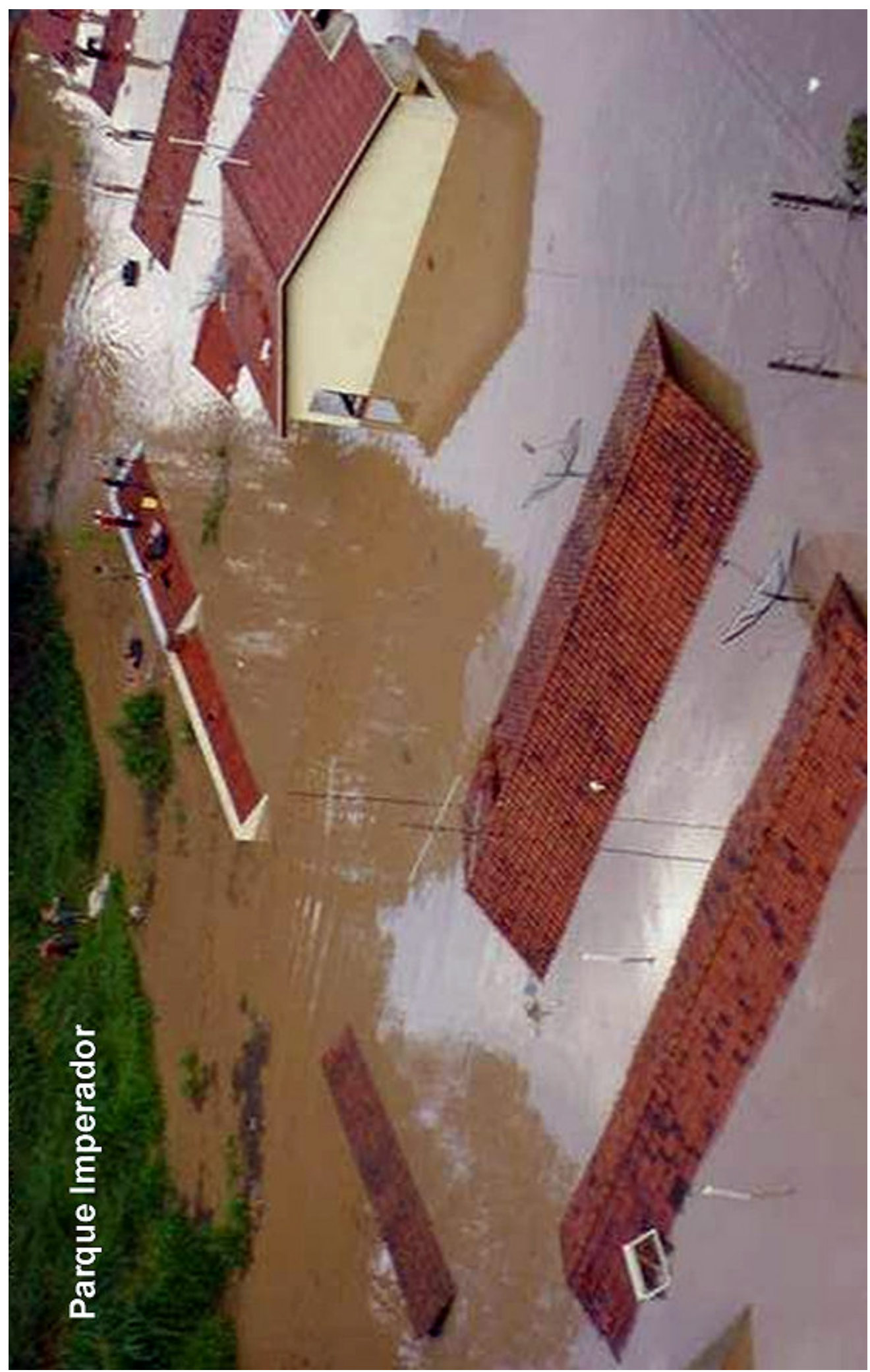


seja transcrevendo um trecho do depoimento de uma das moradoras, que estava dentro de casa no momento da enchente.

(--) foi o rompimento de cinco açudes, que têm em fazendas aqui por perto, e no dia dezessete de fevereiro, como choveu muito, houve o rompimento dos açudes. E esse rompimento é que trouxe um volume de água espantosa, pra cá, pra essa rua. (......) E nessa hora eu estava aqui dentro de casa, estava lendo, tava uma tarde chuvosa, chuva bem forte, mas tava tudo normal. ...De repente, quando eu olhei, pela porta, aqui em baixo da porta de entrada, eu vi, que já entrava uma água lodosa, escura, suja. Mas entrou com muita força, que rompeu a porta, e já entrou na sala e já levantou tudo. E quando eu percebi que a água estava invadindo toda a casa, eu corri pro quarto, onde eu tenho um telefone, e liguei pro meu filho. (...) Aí quando eu tava falando no telefone, a água já entrou nos quartos. Quando entrou nos quartos, que eu olhei, o computador já veio em sentido da porta, eu tava em cima da cama. Quando o computador veio pra cima da porta do quarto, ele comprimiu e foi prensando a porta pra fechar. E eu tinha muito nojo, porque era uma água horrorosa, fedida, horrivel, aí pensei: - Bom, não tenho escolha, vou ter que pisar nessa água. Minha expectativa era que a água parasse, nunca podia imaginar que fosse acontecer o que aconteceu. Aí foi quando eu saltei da cama e agarrei a porta, que foi o tempo que tive pra sair do quarto. Aí eu vim em sentido pra sala aqui, ( ...) Os móveis tavam todos no teto, o meu carro (...) Ele subiu cinco metros, o meu carro, (...)Subi no telhado, (...). Aí que eu tive a noção, a extensão da tragédia, do desastre, foi assim uma coisa horrível! Essa rua aqui, tudo era um mar, parecia..., era uma pororoca, para ser assim mais, era uma pororoca, coisa assim impressionante! Ali, no telhado, eu fiquei um pouco, e a chuva continuava, não tão intensa, mas continuava. (...). Eram cinco e dez quando a água entrou, porque (...), o relógio parou em cinco e dez, por isso eu sei que foram cinco e dez quando a casa realmente inundou, quando eu cheguei no telhado, que eu tava lá em cima. (...) Eu olhei, era esse reloginho aqui, eu falei: - São vinte para as seis! Então foi meia hora aqui dentro, até mais, porque cinco e dez foi que inundou a altura do relógio, quer 
dizer que começou antes, deve ter começado umas cinco horas. Então das cinco às vinte para as seis eu fiquei aqui dentro.

Antecedentes da Inundação.

No verão de 1996 está registrado uma outra inundação no bairro estudado, o Parque Imperador e desta vez a água subiu até um metro e meio, causou muitos prejuízos, algum alarme mas nenhuma vítima. Neste mesmo ano, em abril foi noticiado na imprensa local a concessão de um empréstimo do Banco Interamericano de Desenvolvimento - BID, num total de US\$ 24 milhões para o Programa de Combate às Enchentes - PROCEN, cuja primeira fase no valor de US\$ 13 milhões seria empregado em obras na Bacia do Ribeirão Quilombo e Córrego Piçarrão. O restante do valor seria aplicado nas Bacias do Ribeirão Anhumas e Rio Capivari (figura 3). O PROCEN foi criado em 1996 pela Lei Complementar 004 de 17 de janeiro de 1996, que estabelecia as diretrizes de desenvolvimento urbano em Campinas e no capítulo V, artigo 79 está definido quais seriam os investimentos prioritários para a consecução das diretrizes do Plano Diretor de Campinas e entre elas esta o PROCEN:

I - Programa de Combate às Enchentes no Município de Campinas PROCEN - que consistirá em um conjunto de intervenções na área urbana, agrupadas em 4 microbacias (Anhumas, Piçarrão, Capivari, Quilombo), visando melhorias no sistema de drenagem, ampliação e melhoria no sistema viário, ampliação no sistema de coleta e condução de esgotos sanitários, assim como melhorias em núcleos de favelas;(1996)

IV - investimentos para saneamento do Córrego Piçarrão, Ribeirão Quilombo e Ribeirão Anhumas, envolvendo implementação de marginais, complementação de sistema viário e implementação de interceptores e tratamento final de esgotos;

O PROCEN previa ainda um projeto de educação ambiental para as comunidades afetadas pela obra, na conscientização dos cuidados necessários para a recuperação das áreas degradadas (Martins, 1996), que aparentemente nunca foi implementado. Em setembro de 1996, o município de Campinas através da Defesa Civil resolveu tomar medidas de prevenção das enchentes e alagamentos pela elaboração do Plano Verão, com medidas para a prevenção de enchentes, inundações e alagamentos, e pela criação do CODAR - Codificação de Desastres, Ameaças e Riscos, contendo informações sobre todos os desastres e ameaças no município 
Figura 3 - Mapa das bacias hidrográficas na região de Campinas com a localização do ribeirão Anhumas e do córrego São Quirino

\section{Bacias Hidrográficas}

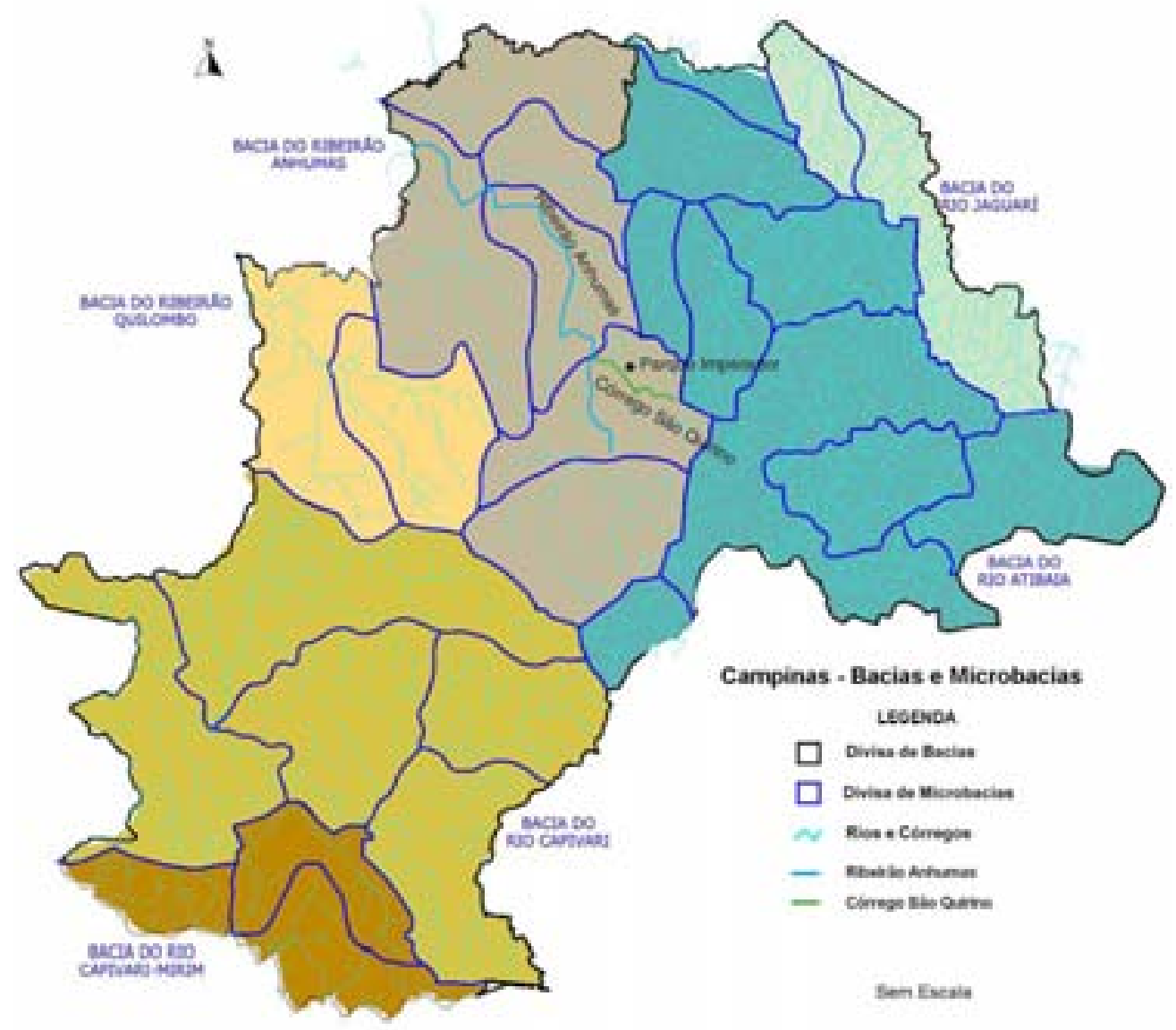

Fonte: Preteitura Municipat de Campinas / Septan Helen Winkiet 
decorrentes de fatores climáticos, ambientais e sociais. A conjugação das informações do CODAR com o PROCEN resultou na identificação de 44 áreas de risco de enchente, caracterizada como o aumento gradual do leito de um curso hídrico, ou de inundação, caracterizada como cheia repentina de um rio ou córrego com efeitos imediatos para a população vizinha ou de alagamento, caracterizado como um concentração de água em alguns pontos que não tem a influência de um curso hídrico. Pela descrição das áreas de risco, é interessante observar que o Parque Imperador não está incluído em nenhuma destas áreas de risco selecionadas, apesar de fazer parte da bacia do córrego Anhumas. Nesse sentido, nota-se que a situação dos açudes localizados no curso d'água, tributário do Anhumas, acima do loteamento Parque Imperador não se constituía em preocupação para o município, embora as famílias entrevistadas relatem muitas notificações junto à defesa civil sobre inundações, tão antigas quanto 1986/87/90 e principalmente 1996 (figura 4). Com relação aos açudes rio acima, os moradores da rua Professora Altimira de Souza Pinto questionavam a forma como eram administrados, mantendo o nível da água muito alto, tendo sido movida uma ação através da defensoria pública solicitando providências junto ao Departamento de Águas e Energia Elétrica DAEE ${ }^{11}$ do governo estadual, para fiscalização dos 5 açudes e deve-se observa ainda, que em 1996 foi encaminhado, através da associação de moradores, uma solicitação acompanhada de um abaixo assinado à Promotoria de Meio Ambiente no município, para que fosse feito uma avaliação do risco que os açudes representavam para os moradores a jusante dos açudes. Na figura 5 pode-se ver através de uma montagem de fotos a localização dos 5 açudes a montante da Rua Prof ${ }^{a}$. Altimira de Souza Pinto com a sinalização daqueles que romperam e dos que foram galgados seguindo o percurso da onda de inundação. Nas figuras 6 e 7 retratam os açudes rompidos e galgados com maior detalhe. Como resultado destas ações, foram regulados o nível de água nos açudes e determinado a ampliação dos dutos de passagem de água no prosseguimento da rua Professor Altimira de Souza Pinto por uma passagem embaixo da linha de estrada de ferro.

\footnotetext{
${ }^{11}$ O DAEE é o órgão no governo do estado de São Paulo responsável pela outorga de direito de uso ou interferência de recursos hídricos o que é um ato administrativo, de autorização ou concessão, mediante o qual o Poder Público faculta ao outorgado fazer uso da água por determinado tempo, finalidade e condição expressa no respectivo ato.
} 
Figura 4 - Vista aérea do curso do córrego São Quirino

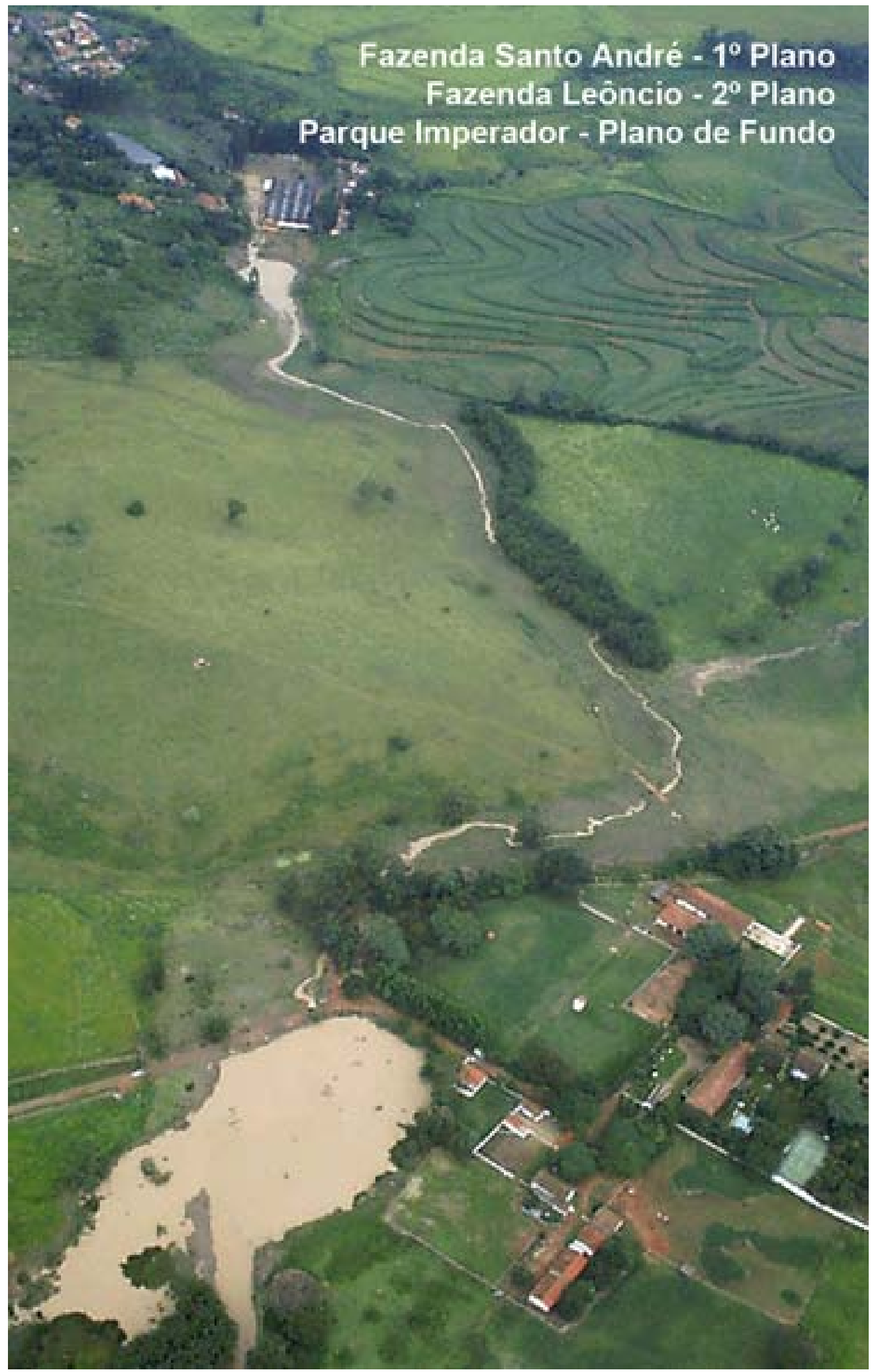


Figura 5 - Simulação do curso da onda da inundação

(A) Barragem Rompida do Haras S9o Quirino

(B) Barragem Galgada

C) Barragem Rompida Fazenda Looncio

(D) Deposito de Moveis Rede Matrix

E Eairro Parque imperador Rua Altimira de Souza Pinto

(F) Travessia de Linha Ferrea

Simulacta do Curso da Onda

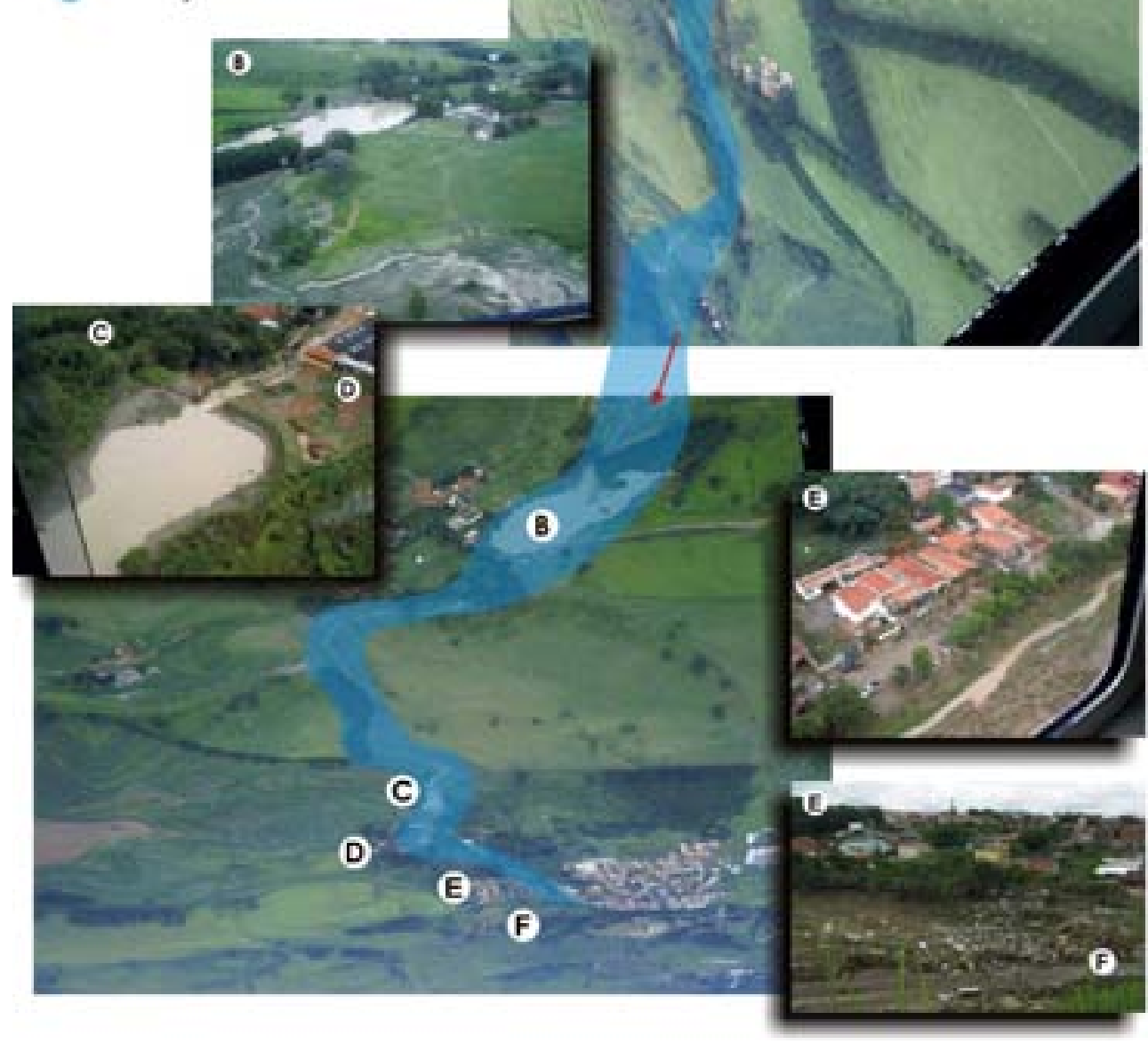


Figura 6 - Barragem galgada . Letra B da montagem anterior

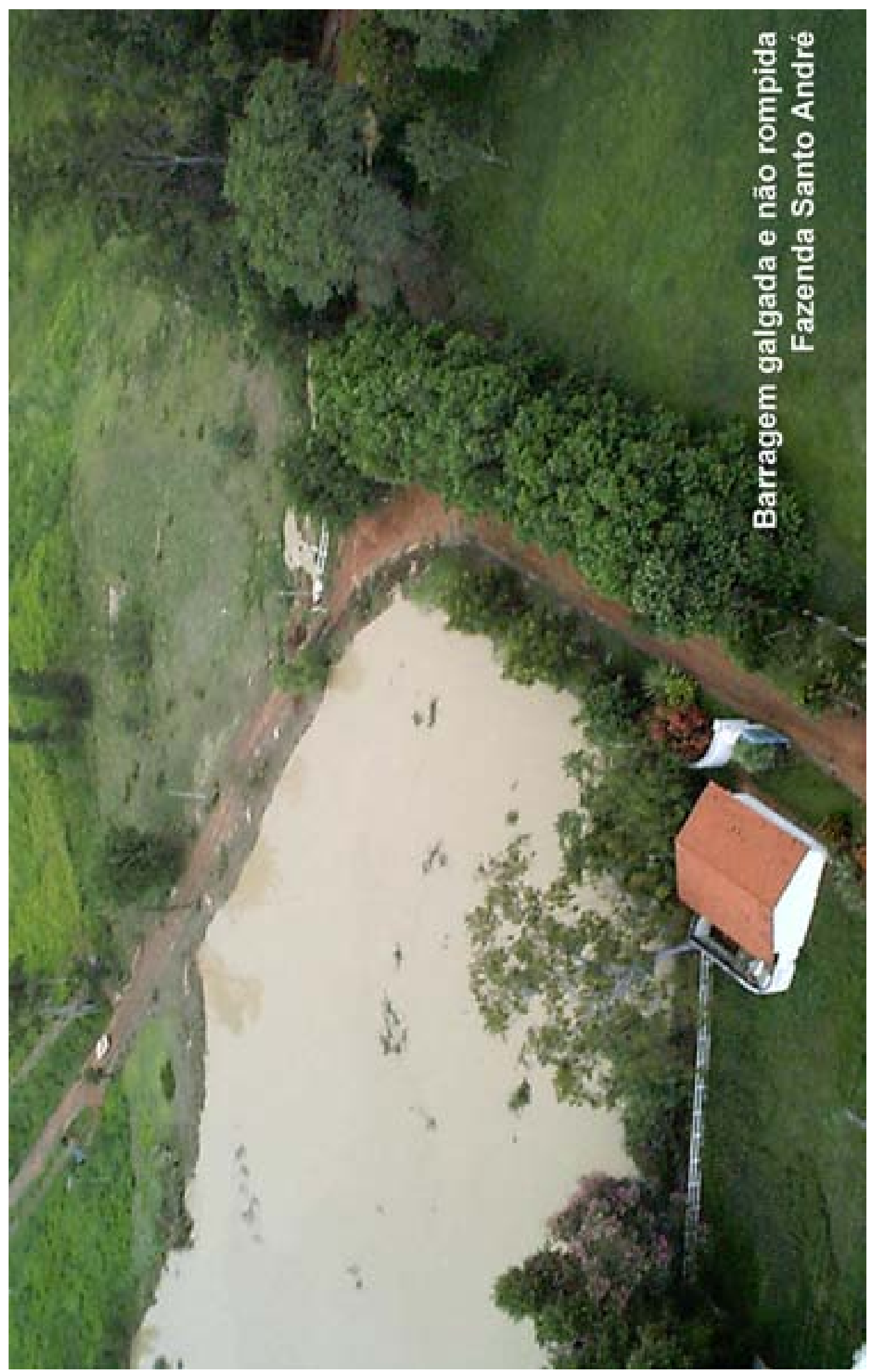


Figura 7 - Barragem rompida. Letra $\mathrm{C}$ da montagem anterior

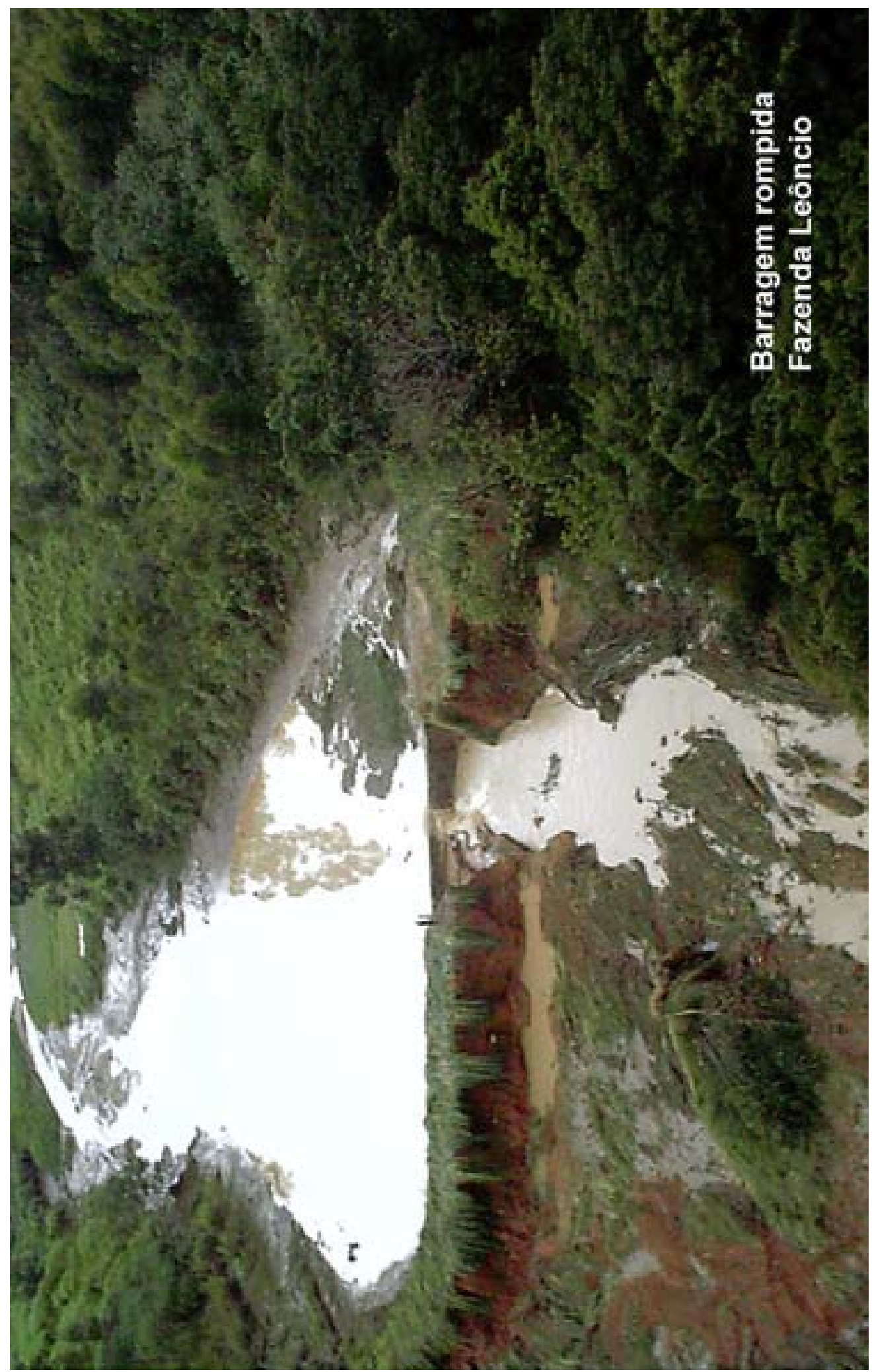




\subsection{Método de coleta de dados:}

Conforme apresentado por Gaskell ( 2002), o mundo social não é um dado natural, ele é ativamente construído por pessoas em suas vida cotidiana. "Estas construções constituem a realidade essencial das pessoas, seu mundo vivencial." Nesse sentido, a entrevista qualitativa é o ponto de partida para a compreensão das relações entre os atores sociais e sua situação e segundo Gaskell (2002) o objetivo é uma compreensão detalhada das crenças, atitudes, valores e motivações em relação ao comportamento das pessoas em contextos sociais específicos. $\mathrm{Na}$ preparação da entrevista ficou definido que a conversação aparentemente natural com os entrevistados seguiria uma agenda onde as intervenções seriam no sentido de obter informações sobre o relato da situação de risco segundo a ótica do entrevistado, seu conhecimento anterior sobre a possibilidade de acontecer a situação de risco, a intensidade de perigo desta situação e de que forma a experiência influiu no seu processo de avaliação atual para a tomada de decisão com relação à mesma situação ou outras.

A seleção dos entrevistados segue o critério de explorar o espectro de opiniões, as diferentes representações sobre o assunto em questão de um "grupo natural”, constituído pelas famílias que moram na área inundada e que compartilham um passado comum e um projeto de futuro. Portanto, ao selecionar os sujeitos para as entrevistas, estes foram considerados por unidade familiar, ou seja, aquele grupo de indivíduos residentes no dia da "enchente". Conforme Gaskell (2002), a entrevista individual em profundidade permite explorar em detalhe a cosmovisão do entrevistado, entretanto, a entrevista em grupo tem como características centrais a sinergia que emerge da interação social; a possibilidade de observação da dinâmica da atitude e da mudança de opinião e de liderança no grupo; e, um alto nível de envolvimento emocional. Nesse sentido, ao se optar pela entrevista em grupo buscou-se ocupar o lugar do moderador que conforme Gaskell (2002) serve como catalisador da interação social entre os participantes. Nas entrevistas são muitos os momentos em que se pode perceber esta interação, como neste trecho em que o pai comenta sua surpresa sobre uma fala da filha:

Filha (...) antes eu ficava com medo, falava para eles que eu não queria mais ficar aqui, ficava perguntando: - Tem certeza que não encheu de 
novo? Tem certeza que não tá mais com água? Ficava perguntando toda vez, ficava perguntando se tinha água.

Pai : Muito interessante que agora essa conversa toda trouxe aqui uma clareza, que até então eu não havia pensado dessa forma, mas eu, por morar aqui mais tempo, por conhecer como se comporta esse córrego e sabendo que condição (...)

Nas entrevistas busca-se a narrativa da experiência, onde as pessoas lembram o que aconteceu, colocam a experiência em seqüência, encontram possíveis explicações para isso e jogam com a cadeia de acontecimentos que constróem a vida individual e social. (Javchelovitch, 2002). Esta forma de reconstruir a história e de construir o significado dos fatos leva em conta que contar histórias é uma habilidade relativamente independente da educação e da competência lingüistica e o acontecimento pode ser traduzido em termos indexados, como foi o caso onde a referência é feita a um acontecimento concreto, em um lugar e em um tempo - a enchente. Referir-se ao acontecimento como - a enchente - já é uma apropriação da forma como a comunidade entrevistada se refere ao acontecido. O contar a história da enchente implica em duas dimensões, conforme Javchelovitch (2002), a dimensão cronológica referente à narrativa como uma seqüência de episódios e a não cronológica que implica a configuração de um enredo, onde o narrador se insere como personagem e atribui um sentido pessoal, particular ao fato coletivo. Dessa forma, o enredo oferece critérios para a seleção dos acontecimentos que devem integrar a narrativa, como eles serão ordenados em uma seqüência que se desdobra até a conclusão da história, e para o esclarecimento do sentido implícito que os acontecimentos possuem na compreensão da narrativa como um todo.

As Entrevistas: procedimentos e técnica:

Os procedimentos desenvolvidos para a coleta de dados através da utilização da entrevista narrativa se processa em quatro fases:

Preparação: Em partes anteriores deste trabalho deixou-se claramente definido os interesses pessoais da pesquisadora no tema que levaram ao conhecimento de áreas de risco na cidade de Campinas. O percurso metodológico até chegar-se à configuração atual começou com a realização de quatro entrevistas 
piloto, com mulheres residentes em um bairro na periferia de Campinas/SP e caracterizado, segundo o plano de desenvolvimento do município, como uma área de risco. Neste caso a área de risco era definida pela invasão sobre um LIXÂO desativado. Trata-se de uma encosta bastante íngreme, limitada no topo pela via de acesso e ao fundo por um córrego que é o esgoto do bairro e se estende por duas quadras no sentido transversal e quatro no sentido longitudinal, acompanhando a via e o córrego limites. Situa-se na região conhecida como Campo Grande, uma vasta região na transição do rural para o urbano que vem sendo ocupada por loteamentos populares com precária oferta de infra-estrutura e de equipamentos urbanos. A ocupação desta região segue o padrão tradicional de desenvolvimento das metrópoles brasileira, ou seja, ao sabor da especulação imobiliária com a reserva de terrenos tendo como conseqüência um malha urbana descontínua com espaços vazios reservados para posterior ocupação, quando estes terrenos tiverem atingido maior valorização, após a extensão da infra-estrutura pelas prefeituras e governos estaduais até às áreas mais distantes. Quando acontecem as intensas chuvas de verão características da região, ocorre o afloramento do chorume, liquido escuro, malcheiroso e venenoso decorrente da decomposição do lixo e o transbordamento do córrego, um esgoto a céu aberto. As vias de distribuição do bairro sofrem um intenso processo de solapamento e criam-se buracos capazes, segundo os moradores, de caber um "fusca". Na abordagem dos sujeitos para entrevista pedia-se que contassem sobre sua vida, como era viver ali _(Pergunta Disparadora.). Verificou-se que apesar de as pessoas terem a experiência da enxurrada, do chorume e do mau cheiro tratavam a questão do risco com desconfiança e descrédito, como podemos ver a seguir nesta entrevista realizada em 24/10/2002 ${ }^{12}$ :

E - “Aqui, era um aterro sanitário da Pirelli. (...) Era o antigo lixão. (...) Por isso mesmo que o Estado não quer que a gente fique aqui. (...) Eles acham que isso aqui é um... tempo pode explodir.

C - "E você acha que tem perigo mesmo de explodir?"

E - "Eu acho que não, porque tem gente que já mora há treze anos aqui. A gente nunca viu nada. Nunca nenhuma criança ficou doente, nunca aconteceu isso.”(...) "Eles acha que pode ficar doente por causa do lixo. Como é que se diz?! Tem gases debaixo da terra...(...) Então, eles acha que a

\footnotetext{
${ }^{12} \mathrm{E}$ - entrevistada; $\mathrm{C}$ entrevistadora.
} 
criança pode ficar doente, pegar uma doença. Só que, graças a Deus, até agora, nunca vi um caso assim de dizer que a criança ficasse doente por causa disso aqui."

Verificou-se, ainda, que as pessoas não se sentiam confortáveis em falar da situação de risco do ponto de vista de uma hipótese. A idéia de um fato ter uma probabilidade de vir a acontecer não é intuitiva e a configuração desta idéia se apoia na manipulação da informação segundo um conjunto de técnicas não triviais. $O$ pensar sobre o risco requer a materialidade do acontecimento a partir de coisas reais. Refletindo sobre o resultado destas entrevistas iniciais, foi feita uma revisão da proposta inicial quanto à seleção dos sujeitos da pesquisa e optou-se por selecionar aqueles que já haviam passado por uma experiência real de risco, conforme explicitado anteriormente.

\subsection{Método de análise dos dados}

A escolha do referencial teórico metodológico para este objeto de estudo - o discurso - apresenta algumas dificuldades com relação ao seu significado. O discurso como objeto de estudo é comum a muitas áreas das ciências humanas, mostrando-se pouco definido e por conseguinte não existe uma única análise do discurso, mas muitos estilos diferentes de análise. Gill, (2000). Conforme Maingueneau (1996), o método da análise do discurso recebe definições bastante variadas ${ }^{13}$ estando em síntese marcado pela antropologia nos Estados Unidos da América e pelo marxismo e pela psicanálise na França, conforme desenvolvida na década de 60. Prosseguindo nesta sistematização, Maingueneau (1996) trata a análise do discurso como uma disciplina que em lugar de proceder a uma análise lingüistica do texto por si só, ou uma análise sociológica ou psicológica de seu contexto, visa articular sua enunciação a um certo lugar social. Portanto, o método se ocupa com os gêneros do discurso construídos em setores do espaço social ou no campo discursivo onde se definem sócio-historicamente os dispositivos de comunicação, como por exemplo, o editorial, a consulta médica, o interrogatório policial, os pequenos anúncios, a conferência

\footnotetext{
${ }^{13}$ Maingueneau destaca algumas definições, tais como de Brown e Yule (1983), onde seria a análise do uso da língua, ou de Van Dijk (1985), onde seria o estudo do uso efetivo da linguagem, pelos efetivos locutores em efetivas situações, ou ainda como entendido nos países anglo saxônicos como uma análise da conversação.
} 
universitária, etc. Há sempre o risco de uma proliferação sem fim de gêneros, portanto dentro de uma perspectiva tradicional se consideram gêneros como as várias molduras que encerram conteúdos. Com a influência de escolas pragmáticas foram consideradas atividades, mais ou menos ritualizadas, que se realizam a partir de regras que as constituem. Por outro lado, uma das tarefas essenciais na análise do discurso é de classificar os discursos que são produzidos numa sociedade. Petitjean (1989), apub Maingueneau (1996), ropôs três classes de tipologias:

- $\quad$ Tipologia enunciativa: fundamenta-se sobre a relação entre o enunciado e a situação de enunciação, com seus três pólos: interlocutor, momento e meio de comunicação. Neste campo, a tipologia básica é aquela de Benveniste entre o discurso e a história onde o plano de engate implica um ajuste por afinidade à situação enunciada, embora num plano de não engate o enunciado se apresenta como desarticulado desta situação de enunciação. Paralelo ao ajuste por afinidade com a situação de enunciação, as tipologias enunciativas podem também dar conta de outros fenômenos, como a presença ou não de marcos de subjetividade enunciativa ou de heterogeneidade.

- $\quad$ Tipologia de comunicação: busca classificar o discurso em função do tipo de ação que pretende executar, da intenção comunicadora que o anima. A mais célebre das tipologias deste tipo é a de Jakobson ${ }^{14}$, que distingue o discurso pela maneira como se hierarquiza as funções da linguagem (referencial, emotiva, conativa, factual metalingüistica e poética). Uma das dificuldades com estas tipologias de função é quando um mesmo discurso está presente em muitas associações e embora esta tipologia repouse em matrizes sociológicas ou filosóficas, sua articulação é muitas vezes mal sucedida devido à complexidade dos gêneros de discursos efetivos.

- $\quad$ Tipologia de situação: promove a interveniência do campo da atividade social em que exerce o discurso. Encontra-se entre as tipologias que distribuem o discurso dentre as diversas zonas da sociedade (a escola, a família, o lazer, etc.) e considera os diversos gêneros de discursos atrelados a um meio; os

\footnotetext{
${ }^{14}$ ROMAN Jakobson 1896 - 1982 seu trabalho inicial baseava-se na lingüistica estrutural e afirmava que o objetivo da lingüistica histórica é o estudo das mudanças sistemáticas na linguagem. Fundador juntamente com outros da Escola de Lingüistica de Praga, argumenta que a fonologia sincrônica, o estudo dos sons do discurso em um língua num determinado momento, deve ser considerada à luz da fonologia diacrônica.
} 
gêneros jornalístico, político, etc. Pode também considerar o status dos participantes do discurso (superioridade/inferioridade, idade, pertencer ou não a um grupo étnico). Por fim, a escola francesa de análise do discurso privilegia o corpus baseado no posicionamento sócio-histórico e não discurso político, como por exemplo o discurso comunista, o discurso brizolista, o discurso petista, etc.

Em meados dos anos 60 surge um grupo caracterizado como a Escola Francesa, que agrupa um conjunto de pesquisadores liderados por Pêcheux (1938$83)^{15}$, e esta abordagem espalhou-se pelos países de língua romântica com foco no estudo do discurso político manejado pelos lingüistas e historiadores, com uma metodologia que associava a lingüistica estrutural conforme a teoria da ideologia inspirada nas releituras feita por Althuser da obra de Marx e por Lacan na psicanálise. Ocupa-se de pensar a relação entre a ideologia e a lingüistica, visando evitar tanto reduzir o discurso na análise da língua como ao contrário, dissolver o discurso na ideologia. Denuncia como ilusão de que o sujeito do discurso seja a fonte do sentido e privilegia as ações analíticas de desconstrução do texto, onde trabalha com a hipótese de que o discurso é um aparato enganador, cuja análise fará revelar suas inconsistências, fundadas no trabalho das forças inconscientes. Entretanto, no início dos anos 80 esta corrente foi marginalizada com o desaparecimento de seus pilares teóricos.

Portanto, pode-se dizer de forma geral que não existe concretamente um modelo de análise do discurso, o que pode vir a representar tanto um complicador, pois fica-se sem um referencial seguro, mas por outro lado amplia as possibilidades de análise do objeto de estudo. Entretanto, para fins de análise dos dados coletados nas entrevistas, o interesse no discurso é parcial e objetivamente o interesse recai sobre a construção do argumento, entendido como uma série de afirmações com o objetivo de justificar ou refutar determinada opinião, e de maneira geral a análise do argumento tem por objetivo apresentar a maneira como as afirmações estão estruturadas no discurso e avaliar sua solidez, conforme apresentado por Liakopoulos (2002), Blackburn (1996) e Rosa (2003). Segundo a Lógica, ciência constituída por Aristóteles para o estudo do argumento dedutivo, este é o conjunto de premissas, mas a conclusão e a atribuição de verdade ou falsidade ao argumento é devido a uma

\footnotetext{
15 Pêcheux, sistematiza esta abordagem a partir de seu artigo mais representativo A Análise automática do discurso.
} 
semântica sem a qual não há possibilidade de verificação da verdade ou falsidade de uma afirmação. A partir da semântica pode-se construir uma sucessão de afirmações ou negações que levem consistentemente, do ponto de vista lógico, a uma conclusão independente da concordância ou discordância com a semântica. ${ }^{16}$ Por outro lado, pode-se também estudar o argumento construído pela lógica indutiva onde se estuda as formas como as premissas podem sustentar um argumento sem seguí-lo. Conforme Blackburn (1996), indução refere-se a um processo de argumentação que nos leva de premissas empíricas a conclusões empíricas sustentadas por essas premissas, porém não as seguem dedutivamente. Argumentos indutivos seriam, portanto, tipos de argumentos ampliativos, conforme Pierce (apub Blackburn, 1996), que vão alem das informações disponíveis de forma a satisfazer nossos interesses ${ }^{17}$. De qualquer forma, qualquer experiência nos revela apenas alguns eventos que ocorrem dentro de uma parte muito restrita de uma vasta ordem temporal e espacial, sobre a qual nós então teremos que acreditar em acontecimentos sobre os quais não dispomos de informação.

O principal interesse desta pesquisa será de reconhecer quais os tipos de argumentos utilizados no processo decisório das pessoas envolvidas na situação de risco descrita e analisá-los sob o ponto de vista lógico, identificando as premissas que são adotadas e resultam numa avaliação dos fatos. Parte-se do pressuposto de que a decisão se situa na esfera psicossocial e que o argumento racional não se introduz no processo decisório, constituindo-se como apêndice muitas vezes de negação da decisão racional ${ }^{18}$. Pretende-se seguir o método proposto por Rosa (2003) e desenvolvido em seu trabalho quando estudando a lógica do sistema jurídico ao proferir as sentenças com relação a maus tratos de pais contra os filhos e trazer o caráter de exterioridade do argumento lógico racional técnico. A relação lógica implica que se for aceita uma afirmação estarão sendo aceitas as suas premissas. A racionalidade exige, precisamente, tornar transparente essa derivação lógica pela via

\footnotetext{
${ }^{16}$ Informação verbal extraída das transcrições das orientações desenvolvidas pela Professora Dra. Eda Tassara.

${ }^{17}$ Como exemplo de inferências seria aquelas de propriedades passadas de um objeto se repetirem a objetos iguais no futuro, ou da constância de leis de padrões sobre eventos ou estado de coisas para seu constante futuro. A base racional destas inferências foi questionada por Hume que acreditava que a indução pressupõe a crença na uniformidade da natureza, mas que esta crença não tem defesa na razão e meramente reflete um hábito ou um costume da mente.

18 informação verbal extraída das transcrições das orientações desenvolvidas pela professora $\operatorname{Dr}^{\mathrm{a}}$ Eda Tassara.
} 
argumentativa, por outro lado, a racionalização refere-se a afirmações cujas premissas são desconhecidas impedindo o conhecimento da argumentação (que leva da afirmação às suas premissas) e impossibilitando, por conseqüência, a crítica. (Tassara \& Ardans, 2004). Pretende-se mostrar que o argumento racional técnico, quando existe, se constitui em um apêndice para a racionalização. 


\section{APRESENTAÇÃO E DISCUSSÃO DOS RESULTADOS:}

Neste capítulo, pretende-se a apresentação dos sujeitos da pesquisa segundo a forma como foram selecionados e abordados e sua inserção social, espacial e temporal no evento catastrófico em estudo. Em seguida, procede-se à análise dos depoimentos.

\subsection{Os Sujeitos Da Pesquisa:}

A todos os entrevistados é sempre explicado o sentido da pesquisa e é solicitado que assinem o termo de consentimento de utilização dos resultados das entrevistas, desde que resguardado o sigilo do entrevistado. Em seguida, é solicitado que o entrevistado relate o ocorrido no dia 17 de fevereiro de 2003. Foram realizadas entrevistas com 5 famílias num total de 9 pessoas.

1. Primeira família: no dia 19 de fevereiro de 2004, fui ao bairro Parque Imperador para conhecer o local onde à cerca de um ano, no dia 17 de fevereiro de 2003, aconteceu um desastre ambiental com características de tragédia. Houve uma inundação, em poucos minutos a água subiu 6 metros cobrindo o vale, inundando até os telhados de 33 residências e causando a morte de 3 pessoas. Entrei no bairro, aguardei um ônibus de linha, que circula por todo o bairro, e passei a seguí-lo, acreditando que teria um tour do local. Dito e feito, circulando atrás do ônibus conheci a parte mais alta onde ficam localizados os condomínios de classe média alta e as moradias também deste padrão. Circulei pelo pequeno comércio local constituído basicamente por uma rua com uma padaria com lanche e bebida por dose e um varejão de hortifruti caseiro na garagem de uma residência e descemos, cruzando a rua Professor Altimira de Souza Pinto, local da tragédia e subimos para o outro lado do rio onde fica o grupo escolar e mais algumas residências de caráter mais popular. Na volta, acompanhei o ônibus até a saída do bairro, quando então abandonei meu guia e voltei para a padaria. Havia selecionado este local para iniciar minha aproximação. Ao entrar pedi uma coca gelada e comecei a conversar com o homem no caixa, que parecia ser o dono do lugar, e após conversarmos um 
pouco sobre o tempo, Campinas está tendo um verão particularmente chuvoso, perguntei pela chuva naquele local e se por ali havia enchentes quando chovia. Ele logo respondeu que não era nada fora do comum e me perguntou se eu estava me mudando para o bairro, tomando-me por uma nova moradora querendo conhecer o local. Confirmei assim minha suposição de que o bairro é um bolsão com apenas uma entrada e saída e que aquele era o comércio e que ele conhecia todo mundo, já que havia de pronto me identificado como alguém de fora. Respondi que me interessava pelo que havia acontecido há um ano e ele me respondeu que aquilo havia sido um episódio isolado e que não havia mais nenhum problema. Meio que concordando perguntei se ele conhecia a Dona Neuza (pessoa indicada no jornal como a sobrevivente de uma família), ao que ele respondeu que sim e me indicou imediatamente onde ela morava. Perguntei o que ele achava de eu ir lá conversar com ela e ele logo me afirmou que não tinha o menor problema, que ela conversava com todos e que não tinha o menor problema em falar sobre o acontecido. Ante minha dúvida ele insistiu, me indicando mais precisamente a casa de sua mãe onde ela agora morava e já me informando que ela talvez não estivesse em casa mas sim no hipermercado próximo, onde trabalhava. Agradeci e sai procurando a casa que ele havia me indicado, localizada na rua de cima do ocorrido, quase na esquina, de onde os moradores devem ter tido uma visão privilegiada dos acontecimentos. Ao chegar, havia um senhor idoso na calçada do vizinho arrumando alguma coisa e eu the perguntei se aquela era a casa da mãe da Neuza e ele afirmou que sim, logo me avisando que ela não estava em casa, mas sim no trabalho, no hipermercado, e ante minha hesitação insistiu para que eu tocasse a campainha, me indicando o local e dizendo para eu falar com a mãe dela. Sentindo-me acolhida resolvi tocar a campainha e apareceu uma senhora afável de cerca de 60 anos a quem me apresentei dizendo meu nome, minha vinculação com a universidade e expliquei que gostaria de conversar com Neuza sobre o acontecido em 17 de fevereiro do ano anterior. Ela explicou-me que Neuza estava no trabalho e insistiu para que eu fosse lá falar com ela, fornecendo as orientações de onde encontrá-la no setor em que trabalhava. Perguntei se Neuza tinha telefone e se podia me dar o número e ela sem objeções me informou. Despedi-me, e face tanto ao acolhimento ou por curiosidade, ou enfim ! Resolvi ir ao hipermercado procurar Neuza. Ao chegar, segui as orientações recebidas localizando logo seu 
setor e dirigi-me a uma mulher com cerca de 40 anos, que achei que poderia ser a Neuza e acertei. Expliquei que era professora universitária fazendo uma pesquisa com pessoas que haviam passado por uma situação de risco e que estava interessada em ouvir a história dela. Ela prontamente se dispôs a falar dizendo que achava que tinha que falar mesmo muito sobre aquilo e contar para todos que quisessem ouvir, porque aquilo não podia ficar assim esquecido como se nada tivesse acontecido. Pedi, então, para marcarmos uma hora onde ela achasse mais conveniente e após ela verificar seus dias de folga no serviço, marcamos para um domingo, pela manhã, em sua casa. Ao nos despedirmos, ela começou a relatar como sua vida havia mudado de uma hora para outra, que tinha uma família e agora não tinha mais e que aqueles momentos não saíam de sua mente e muitas vezes precisava se afastar do trabalho e ir fumar no estacionamento ou chorar para se reequilibrar. Falou de como os companheiros de trabalho eram solidários, no que uma colega sua concordou, dizendo que achava ser melhor para a Neuza falar sobre o acontecido para poder melhorar. Perguntei se ela conhecia outras pessoa da rua que poderiam estar dispostas também a conversar e ela me indicou mais dois nomes me dando o telefone de um deles. Passei, então, para ela meu telefone e pedi que se houvesse algum contratempo com relação à entrevista que ela me avisasse e nos despedimos. Participou da entrevista também seu filho João, com 22 anos, pai da criança que morreu vítima da enchente.

2. Segunda família: em 24 de fevereiro pela manhã recebo um telefonema de Raul onde ele se apresenta como morador do Parque Imperador e que a Neuza havia passado meu telefone para ele. Ele fala que após o acontecido havia sido escolhido como representante dos moradores e que todos haviam se unido muito e que a Neuza o havia procurado contanto de nossa conversa e que ele havia ficado preocupado com ela, porque todos ali se preocupavam muito devido a ela ter sido a maior vítima do acontecido. Enfim, entendi que ele estava querendo saber mais sobre meu interesse e já que ele era um líder do local era melhor eu tranqüilizá-lo. Assim, expliquei qual era meu interesse e que eu não tinha a intenção de provocar nenhum mal a Neuza nem a ninguém no bairro e que gostaria inclusive de conversar com ele e também outros moradores e que havia começado pela Neuza 
pelas circunstâncias, porque seu nome havia saído no jornal. Ele foi sempre muito afável, afirmando que não tinha nenhum controle sobre a situação e que estava apenas ligando como um interessado, já que ela o havia procurado para trocar uma idéia. Propus, então, que começássemos a entrevista por ele e sua família já que a data marcada com a Neuza seria para daí há 10 dias. Ele concordou, mas disse que ligaria mais tarde para acertarmos a data, já ficando meio combinado que seria melhor no fim de semana. Com a chegada do final de semana e ele não tendo telefonado, achei que poderia tomar a iniciativa e telefonei para marcar a entrevista. Notei que ele ficou um pouco surpreso mas concordou com em marcar para o domingo próximo às $10 \mathrm{~h}$. Foram realizadas duas entrevistas sendo que na primeira participou também sua esposa Solange e na segunda além de sua esposa, suas duas filhas, Mariana de 19 anos e Claudiana de 27 anos.

3. Terceira família: fui encaminhada a este casal Lúcia e Mário por Raul e família que telefonaram para eles durante nossa última entrevista explicando o sentido da pesquisa em andamento. Passaram o telefone para mim, quando já fiz o primeiro contato e marcamos de telefonar mais tarde na semana para acertarmos o horário. Após duas ou três tentativas, acabamos acertando o horário para $6^{\mathrm{a}}$ feira, $12 \mathrm{de}$ março de 2004, às 17h, na casa deles. Ao chegar fui recebida por Lúcia, uma mulher aparentando 50 e poucos anos, muito arrumada com cabelos penteados que me recebeu com polidez, porém uma certa reserva e assim permaneceu por grande parte da entrevista. Convidou-me a sentar em um sofá na sala, avisando que Mário, seu marido, chegaria daí a pouco. Desculpou-se pelo atraso explicando que ele havia ido ao médico e que este havia atrasado. Respondi que não tinha importância e que poderíamos começar por ela, caso ela não se importasse. Lúcia foi a primeira pessoa entrevistada que estava presente, dentro de casa, no momento do acidente e eu estava interessada em conhecer suas impressões e como ela havia escapado com vida. Seu marido chegou cerca de 30 minutos após e participou da entrevista.

4. Quarta família: cheguei ao casal Luís e Maria encaminhada por Lúcia e Mário. Falei com Luís pela primeira vez ainda da casa de Mário e combinamos um encontro para um domingo pela manhã, dia 28 de março de 2004. A entrevista começou com Luís e após 30 minutos sua esposa Maria se juntou a nós e dos dois 
filhos do casal, apenas o rapaz com cerca de 20 anos estava em casa mas não participou da entrevista. Luís estava em casa no momento da enchente com dois cachorros e teve bastante dificuldade em sair, pois não sabe nadar e tem alguma dificuldade em andar devido a um defeito nas pernas. Teve leptospirose em função da enchente e quase morreu afogado, sendo resgatado do telhado de sua casa pelo corpo de bombeiros. Sua esposa Maria não estava em casa na hora da enchente e quando chegou no bairro, Luís ainda não havia sido resgatado.

5. Quinta família: a filha mais moça de Raul telefonou-me pedindo se eu podia entrevistar sua amiga Eliane, que havia passado pelos mesmos problemas que eles e que estava muito abalada ainda com toda esta situação, e me passou seu telefone. Falou, ainda, que havia contado a ela como havia sido nossa entrevista e que ela havia dito que gostaria muito de também participar. Sendo assim, no dia seguinte liguei para Eliane e marcamos um dia pela manhã. $\mathrm{Na}$ véspera do dia marcado liguei para confirmar e ela pediu para mudar o dia já que no dia marcado seria feriado e ela não teria tempo. A entrevista ocorreu em 12 de abril de 2004, quando cheguei à sua casa que ainda tem bem visíveis as marcas da enchente, com paredes recém construídas e ainda sem reboco e o muro inacabado. Ao entrar fui recebida por sua mãe, que sabia quem eu era mas não sabia da entrevista e chamou a filha que estava acabando de se arrumar. Ao chegar na sala Eliane se desculpou pelo atraso e começamos a entrevista ali mesmo. Após alguns minutos ela sentiu-se constrangida com a presença da mãe e pediu para mudarmos para seu quarto, onde continuamos a entrevista. Eliane, com 18 anos, tem uma aparência frágil que disfarça com certa endurecimento de suas feições que são entretanto bastante delicadas. Durante a entrevista ela não quis que ninguém mais na casa participasse.

\subsection{Categorias de Análise:}

Considerando a grande quantidade de material coletado e disponível para análise, busca-se organizá-lo de forma a tornar possível a compreensão dos tipos de argumentos utilizados no processo decisório das pessoas envolvidas na situação de risco descrita e analisá-los sob o ponto de vista lógico, identificando as premissas que são adotadas e resultam numa avaliação dos fatos. Espera-se tornar claro que a decisão situa-se na esfera psicossocial e que o argumento racional não se introduz no 
processo decisório constituindo-se como apêndice, muitas vezes de negação da decisão racional. Neste sentido, busca-se demonstrar como não está transparente a derivação lógica entre premissas e argumento que resultariam numa avaliação crítica da situação. Busca-se, por outro lado, evidenciar o processo de racionalização onde as afirmações originam-se em premissas desconhecidas impedindo o conhecimento da linha argumentativa e impossibilitando o exercício da crítica. (Tassara \& Ardans, 2004).

Todos os nove depoimentos estão organizados a partir de três categorias de análise: percepção do fato, premissas do argumento e argumento. Verifica-se que nem todos os entrevistados chegam a configurar uma avaliação crítica dos acontecimentos e, portanto, esta questão só é abordada nos casos em que está presente. Por fim, no processo de análise identificou-se ainda em alguns depoimentos, mas não em todos, uma tentativa de guardar "relíquias" da tragédia, o que também merecerá nossa atenção.

A. Descrição do Fato: a descrição da experiência, segundo o relato dos entrevistados, que se constitui no fato básico sobre o qual há a possibilidade de construção da avaliação crítica. Optou-se por nomear os entrevistados com nomes fictícios, buscando-se facilitar o acompanhamento das idéias presentes nos depoimentos.

B. Premissas: neste item os depoimentos estão organizados, destacando-se as proposições que compõem um silogismo em que está baseada a conclusão. Busca-se apresentar as idéias iniciais que estariam presentes na formação do raciocínio e que levariam ao argumento. (Houaiss, 2004. Blackburn, 1998). Essas idéias, proposições, foram organizadas em três grandes itens, a saber:

i) familiaridade com os antecedentes das enchentes, informações locais e parecer técnico: Neste item busca-se destacar nos depoimentos das vítimas das enchentes, seu conhecimento anterior sobre as enchentes que já haviam ocorrido naquele local, seja pela experiência própria de morador antigo, seja pelos comentários de vizinhos, seja pelos jornais, ou pela familiaridade com um tema, "enchente", usual entre qualquer morador de Campinas, conforme exposto acima. 
ii) percepção da ameaça de perda de sua identidade social, psicológica e física: Neste item busca-se destacar nos depoimentos das vítimas sua percepção sobre a ameaça que a situação de enchente representou ou representa para sua vida, manifestada também no relato da perda dos registros de sua história anterior, representada nos documentos, fotos, pertences, pessoas e outras.

iii) percepção da mudança interior: Neste item, busca-se destacar nos depoimentos das vítimas um testemunho da metamorfose de sua identidade, representada por valores que sustentam uma transformação na forma de pensar sobre si mesmo e sobre a forma de conduzir a vida.

C. Argumentos $^{19}$ : Neste ponto, acredita-se ser de interesse que antes de caracterizar-se as categorias de análise, que se estabeleça um consenso sobre o que se irá entender por argumento. Considerando a acepção jurídica, argumento constitui-se no raciocínio que conduz à indução ou dedução de algo ou ainda recurso usado para convencer alguém a alterar sua opinião ou comportamento, sendo interessante observar que a ciência jurídica desenvolve uma extensa categorização dos argumentos segundo sua intenção, como por exemplo, o ab absurdo, argumento no qual é admitida a idéia contrária a que se defende para chegar a uma conclusão favorável; o contrario sensu, onde se apresenta como argumento contrário à posição contida em um texto ou o $\mathrm{ad}$ hominem, argumento que apela para os sentimentos e não para a razão e os conhecimentos do juiz ou do adversário ou argumento com o qual se procura confundir o adversário, opondo-lhe suas próprias ações ou palavras (Houaiss, 2004). Por outro lado, do ponto de vista da lingüistica seria uma proposição a respeito do qual é feita uma predicação (Houaiss, 2004). Entretanto, para tentar entender a descontinuidade no argumento presente no discurso das vítimas da enchente representada em dois planos em paralelo, o racional e o razoável, busca-se referência no conceito de negatividade compreendido como o “repúdio por projeção de uma idéia que acaba de ocorrer" (Freud, 1925). Através deste processo psicológico, o racional toma conhecimento de uma

\footnotetext{
${ }^{19}$ Argumento não segue a definição rigorosa conforme a ciência Lógica e será tratado na linguagem natural
} 
idéia inconsciente carregada de afetividade, sem porém ter que aceitá-la, isto é, incluí-la no processo de compreensão da experiência. Observa-se que o processo intelectual racional permanece separado do processo afetivo onde as idéias estão carregadas de emoções. A aceitação do conteúdo de um pensamento integra a construção do argumento e a negação de uma idéia existente na construção de um argumento é reprimí-la, ou seja, impedir por um processo psicológico que ela produza seus efeitos na compreensão do presente e na construção do futuro. Portanto, na avaliação de uma situação, a negação de algumas qualidades ou características da situação pode ser considerada como a expressão de uma processo psicológico onde o indivíduo que nega expressa sua preferência de que aquela qualidade não estivesse presente. Freud, ao tratar deste processo psicológico da negativa (Freud, 1925, p.297), desenvolve uma série de proposições com grandes implicações sobre a compreensão do processo de tomada de decisão pelo, indivíduo, passando pela avaliação da situação, afirmando ou "desafirmando" que uma idéia tenha existência na realidade. Qual poderia ser a razão para este procedimento? Inicialmente, no processo de construção da identidade o indivíduo tende a introjetar aquilo que considera bom como algo seu e aquilo que é considerado ruim é projetado na realidade externa ao eu. Neste sentido, a negação de uma idéia como que “extrai" a mesma da identidade do sujeito. É ele mas também não é. Para a teoria psicanalítica, este processo intrapsíquico é fundamental na estruturação da identidade e ainda determina para o indivíduo a diferenciação entre o mundo subjetivo interno, o eu e o mundo objetivo externo ao eu, a realidade. Para a construção da relação entre o indivíduo com o mundo externo, torna-se necessário um outro processo que se estruture sobre este primário anteriormente descrito, onde o indivíduo busca ordenar as percepções que estão integradas ao eu e que serão redescobertas no mundo real. Esta distinção externo $\mathrm{x}$ interno pode também estabelecer a diferença entre o subjetivo e o objetivo, entre a fantasia e a realidade. A sobrevivência do indivíduo, não apenas do ponto de vista físico mas também psicossocial, implica que um atributo bom possa estar dentro do sujeito e possa também ser reconhecido na realidade onde o sujeito pode apossar-se dele. Este processo do pensar, secundário ao primeiro, é fundamental na avaliação que o indivíduo faz sobre a 
realidade caracterizada como o lugar de reencontro dos objetos primários bons e estabelece um sistema de avaliação entre realidade e fantasia, entre objetivo e subjetivo onde o pensar possibilita o recordar de experiências percebidas anteriormente, possibilitando que esta seja reproduzida no presente, mais ou menos fielmente, como representação simbólica do real. Neste sentido, avaliar o risco para a sobrevivência do eu, em uma determinada situação, é uma ação intelectual que decide a qualidade da ação motora que elimina o intervalo entre o pensar e o agir. Entretanto, esta ação intelectual, racional, é impulsionada pelas forças inconscientes e ao voltar-se para o mundo externo pode tanto confirmar o reconhecimento das representações internas no mundo externo e vincular-se a ele como pode, na negativa do reconhecimento, cortar o vínculo com o mundo externo. Este processo psicológico, denominado por Freud de negativa, impede o contato com o eu e inibe a atribuição de sentido à função senso percepção, por estar entre a repressão e a avaliação. Portanto, o exercício de avaliar só é possível após a criação do símbolo da negativa, que dota o pensar de uma liberdade para refletir sobre o reprimido, sobre o que é percebido como mau e, neste caso, ameaçador para o eu. Neste sentido, optouse por apresentar os argumentos dos entrevistados com relação a dois grandes grupos de idéias, conforme a seguir.

i) A escolha do local de moradia antes do desastre: quais as idéias, de ordem psíquica, social, econômica, afetiva, fantasiosas ou não que sustentaram a decisão de ir morar naquele lugar específico, considerando-se que uma decisão desta monta com implicações em todos os aspectos da vida de um indivíduo passa por um processo de elaboração complexo, embora nem sempre consciente.

ii) A decisão de voltar para morar no mesmo lugar depois do desastre: quais as idéias, de ordem psíquica, social, econômica, afetiva, fantasiosas ou não, que sustentaram a decisão de voltar e reconstruir sua vida no mesmo local em que foi destruída. Em alguns casos, percebe-se neste argumento um esboço de avaliação crítica sobre o papel do sujeito em toda esta história em que o indivíduo se coloca como protagonista, seja na decisão de escolha do local, seja no agir transformador da realidade, de forma a prevenir a repetição deste desastre. 


\section{Relíquias: ícones de uma travessia}

$\mathrm{Na}$ análise crítica dos depoimentos fez-se evidente uma certa atitude, comum a muitos dos entrevistados, de guardar objetos como recordação do ocorrido e a qualidade destes objetos é singular, trata-se de objetos com uma peculiaridade que poderia se chamar de inoperância, como por exemplo, máquinas fotográficas destruídas, discos inutilizados e sem possibilidade de serem tocados, mesmo porque o aparelho de tocar os discos se foi, quadros que não representam nada para aqueles que os retêm, vidros de esmalte de unha tomados pelo barro e fotos, muitas fotos, de uma realidade que não mais existe. Estes objetos foram encontrados no rescaldo e muitas vezes são de ninguém e de todos ao mesmo tempo. Parece que o significado destes achados guarda o sentido de relíquias, ainda mais considerando a origem etimológica desta palavra, como migalhas que ficam entre os dentes depois de comer, resíduos de uma destruição pelo mastigar (Houaiss, 2004). Por outro lado, relíquia é um termo bastante utilizado na obra Psicanalítica com sentidos interessantes para o que se quer compreender. Em geral, é usada para referir-se a algo como que um fragmento de um fato integrante da historia primitiva constitutiva do sujeito que não pode ser lembrada, mas também não pode ser ignorada ou anulada, sob pena de desarticular o eu, tendo como resultado um sujeito sem referências de tempo e espaço. Freud, tratando de representação de símbolos nos sonhos, coloca que "a relação simbólica parece ser uma relíquia, é um marco de identidade anterior" (Freud, 1900). Em outras passagens, principalmente nas obras ditas culturais, encontram-se outros importantes usos para relíquias, referindo-se ao substrato na constituição dos mitos populares, das expressões idiomáticas, da sabedoria dos provérbios e dos chistes (Freud1905). Nesse sentido, o costume de alguma prática cultural se estabelece como relíquia da renúncia à pulsão e ao desejo decorrentes do mecanismo da repressão de impulsos e estas produções do psiquismo, relíquias, nos proporciona material para preencher as lacunas em nosso conhecimento de tempos anteriores. No caso estudado, podería-se fazer um paralelo em que a comunidade da Rua Altimira de Souza Pinto acabará por elaborar um mito a partir de relíquias que serão parte constitutiva da história daqueles sujeitos, daquela rua, daquele bairro e daquele desastre. Em Totem e Tabu (Freud 1905), ao estudar os mitos fundantes da cultura que possibilitam a vida em sociedade, Freud analisa como 
podemos conhecer a história de períodos pré-históricos pelas informações sobre sua arte, religião e atitudes para com a vida que nos chegam através de relíquias de seu modo de pensar. Ainda neste livro trata de como o totem tem um pouco este sentido de relíquias considerando que está no lugar daquilo que é reprimido e sob o que não se pode falar mas também não se pode esquecer. (Freud, 1905). Continuando neste mergulho na psicanálise, buscando a compreensão do sentido destas relíquias, podese ressaltar quando ao analisar o papel de mitos religiosos considerá-los como "uma relíquia neurótica", entendendo-se que a neurose tem a característica da distorção da realidade dura e crua. Estas tentativas de atribuição de sentido e intenção ao encontro destas relíquias, como algo que pertenceu ou entrou em contato com o santificado e atribuir a estes objetos a transmissão de alguma mensagem messiânica que ameniza a dor de ter que "admitir para si mesmos toda a extensão de seu desamparo e insignificância na maquinaria do universo; não podem mais ser o centro da criação, o objeto de terno cuidado por parte de uma Providência beneficente.” (Freud, 1927 item IX). 


\subsection{Análise dos depoimentos:}

Em seguida serão apresentados fragmentos dos depoimentos por entrevistado dentro de cada família, segundo as categorias de análise definidas no item anterior.

\subsubsection{FAMÍLIA 1:}

Entrevista com a mãe nomeada Neuza e o filho nomeado João. Todo o relato de Neuza é bastante ansioso enquanto João mostra-se sereno.

\section{A. Descrição do fato :}

NEUZA: Não estava na casa na hora da enchente

... no dia 17 de fevereiro, (...)eu fui trabalhar com uma sensação assim, levantei com sensação de um vazio, de uma dor que eu não tinha como prever o que estava acontecendo, o que estava acontecendo comigo, mas aquele dia eu estava muito mal, (...)Quando eu cheguei lá eu não conseguia sentar na frente de um micro, não conseguia me concentrar, não conseguia trabalhar, aí fui para a cantina (...)Tava relampeando. Quando eu cheguei na cantina a chuva desabou, aí eu comi duas colheradas de comida e saí na porta dos funcionários. Daqui a pouco eu vi um helicóptero sobrevoando a Moscou, um tipo daqueles ganchos tentando tirar um bebê,(...) aí eu falei para um rapaz que tava comigo: - O quê que está acontecendo? Ele falou: A inundação, que está enchendo. Eu falei: - Eu vou embora para casa.

Bom, quando eu cheguei... (...). Quando nós paramos, a água já tava, já tava..., mais da metade da rua e é uma subida, eu cheguei para minha mãe: Mãe, o que está acontecendo, cadê as meninas? Minha mãe disse: - Eu não sei. Meu pai já tava lá do lado de fora, tinha aglomeração de gente, tinha acabado de cair aquela tempestade, estava tudo molhado, tava um clima terrível. Só que aí todo mundo já sabia que eles estavam lá dentro e que eu não sabia. Eu acho assim, que uma mãe, ela nunca enxerga aquilo que tá acontecendo, a esperança de uma mãe é a última que morre. Eu saí, eu dei umas três idas e vindas: - aí tá aqui, tá ali, o povo me engrupia, - ela está na gráfica, na casa de não sei quem. Eu batia nessas casas com um maior 
desespero - As meninas estão aqui? O Sebastião tá aí? Você viu eles? Eu não achava.

Quando eu olhei lá para baixo, eu vi o ponto da minha casa, o telhado da minha casa submerso, ele tinha uma pontinha, tava todo cheio de água, o que eu fiz? (Figura 8) Eu falei: - Bom, eles não estão mais lá. Era o que eu pensava, que eles não estavam mais lá que tinham tirado eles de lá, as coisas normal, tudo bem. Foi quando eu comecei a ver pessoas em cima da casa, tinha um amigo do (meu filho), tinha o meu vizinho que correu, tinha um outro de barco. O helicóptero demorou muito para chegar, porque também naquele dia foi um caos em Campinas, e eles estavam todos muito empenhados. Me chamou a atenção quanto a pessoas em cima da minha casa, mas eu não pensei porque que eles tavam lá dentro. Até meu irmão chegou, falou para o meu pai: - Segura ela! E foi pela beirinha do mato, desceu e nadou até lá e eu vi meu irmão lá em cima da casa. Aí já tinha bombeiro, o helicóptero voando, os meninos meus vizinhos pegaram o caminhão e bateram o foco de luz, já tava assim escurecendo. E eu ali eu não tinha nenhuma....tinha certeza que Deus não ia deixar acontecer nada com as meninas e nem com o Sebastião. Eu vou tirar eles e depois eu vou ver o que vai acontecer comigo, aonde eu vou ficar, eu acho que alguém vai me amparar e quando eu ouvi meu irmão gritar: - Eu achei! Quando ele gritou "eu achei", é ... o bombeiro já tava lá em baixo, o bombeiro desceu e desencostou a minha geladeira que tava boiando. Quando ele desencostou a geladeira o corpo da minha filha apareceu, a Fernanda. É ele já tava, o Sebastião, foram achados na cozinha, ele com aquela sensação de tirar as meninas de lá, porque era um amor muito grande pelas meninas, ele falava que ele dava a vida delas por ele, dava a vida dele por elas. 
Figura 8. Vista aérea da residência de D. Neuza

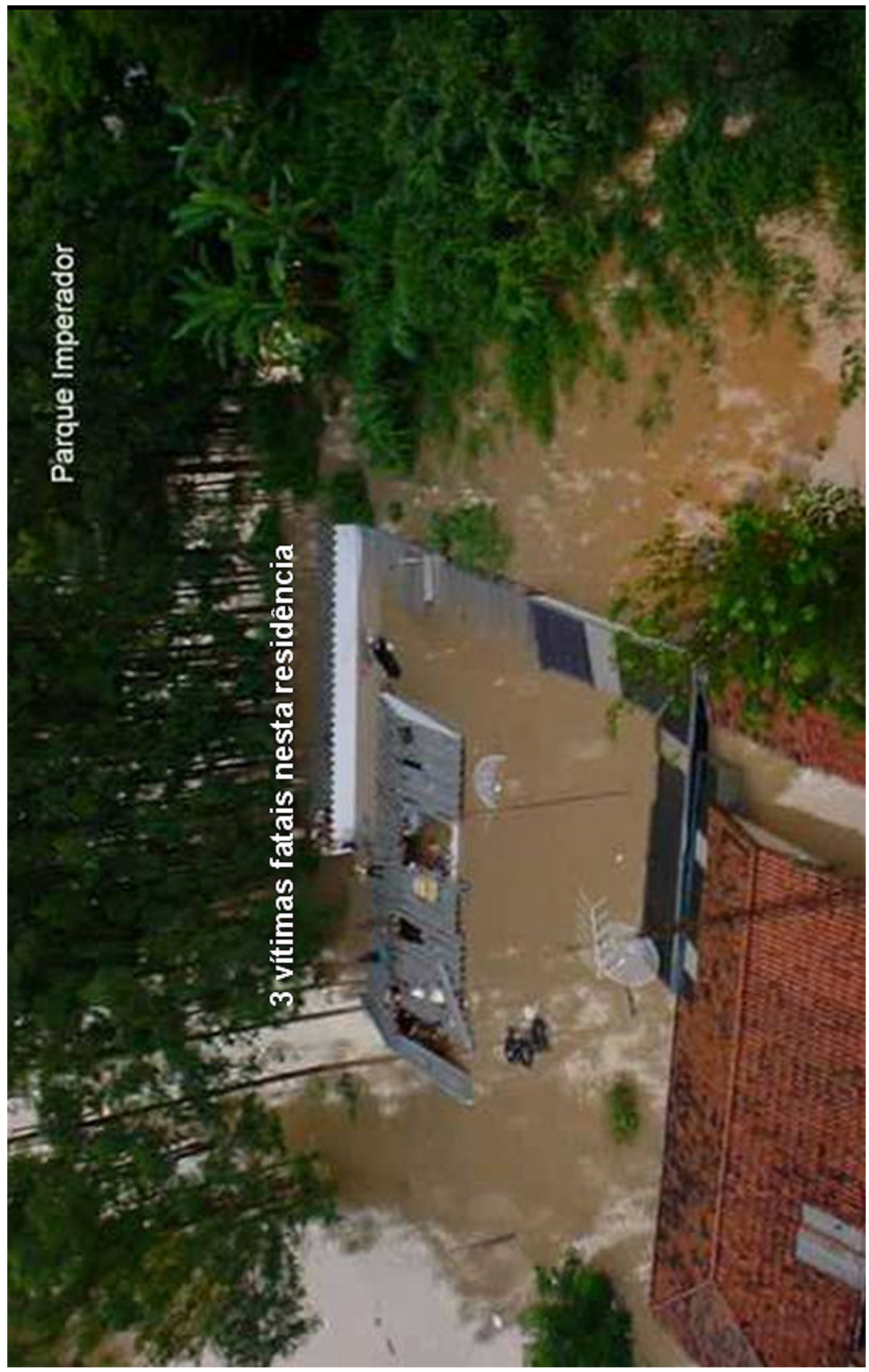


Ele deu um soco com a mão na porta para tentar que abrisse a porta, mas a água, ela trava tudo e lá na minha casa tinha grade de proteção, todas as janelas tinham grade, então não tinha como sair também, e ele com um bebê de um ano e dois meses e a minha filha com vinte e dois, então não dava mesmo para conseguir sair daquela situação. Bom, na hora que meu irmão gritou, a Fernanda subiu e logo após veio o Sebastião. Porque a gente andava dentro de casa assim, como eram duas para andar, então a Fernanda segurava aqui (mostrando o cós da calça) e a gente segurava o bebê, então onde ia um ia os três juntos. Ela tava grudadinha na calça do pai, e quando subiu ela, subiu ele, eu olhei assim e via ela embrulhada num lençol e falava não, não é nada, e vi que era minha filha sim e aí eu caí num desespero total. (figura 9) 
Figura 9 - Corpos das 3 vítimas aguardando remoção

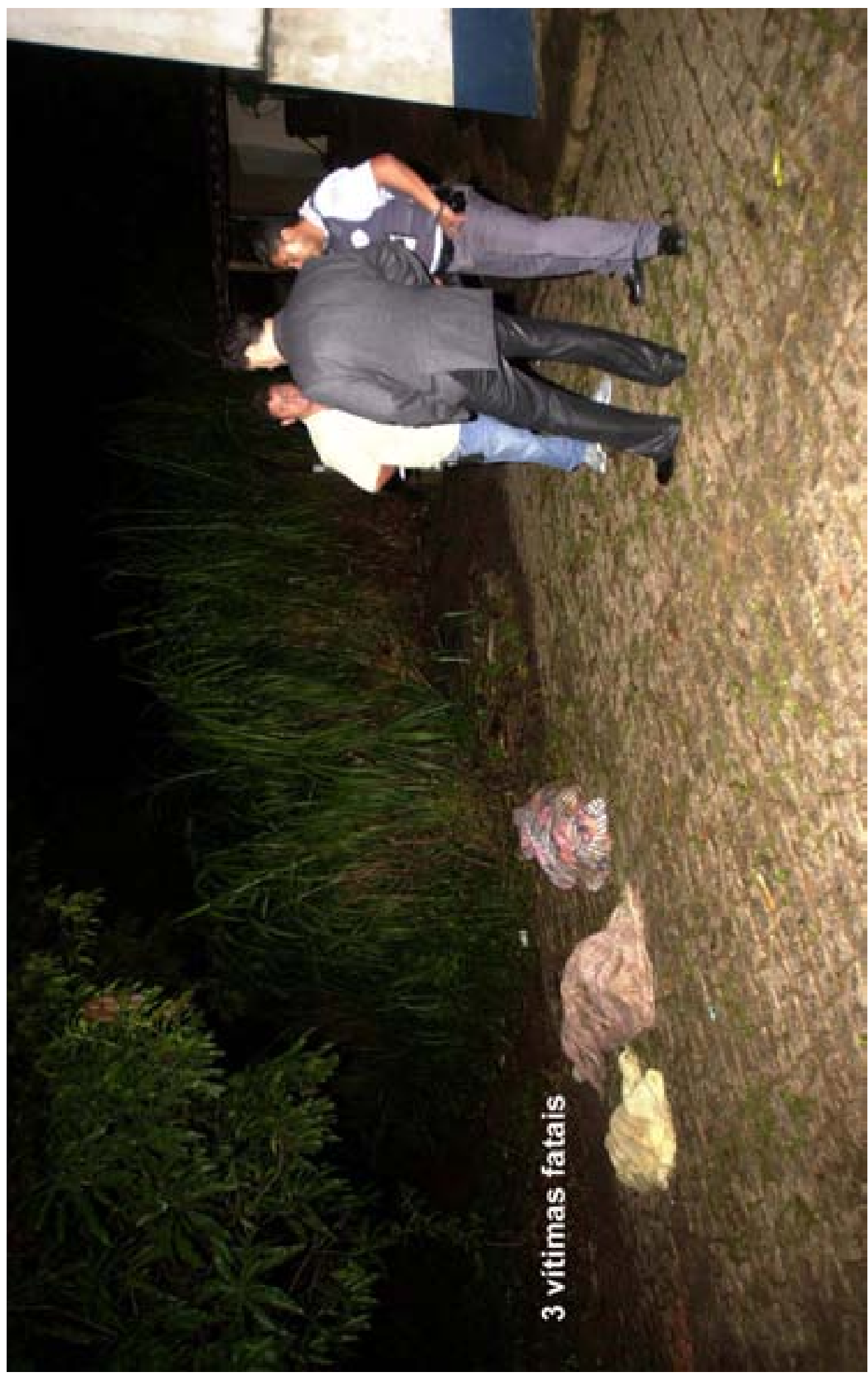


Eu parei aquela hora, aquela hora eu consegui zerar como ser humano, eu consegui chegar a zero em mim, eu senti uma sensação de mal estar, que meu coração ia estourar de tanto sofrimento àquela hora. Aí eu vi tirar Sebastião, eu não vi tirar Clara, eu não vi tirar porque o corpinho dela era muito pequeno, ela já ia rodar na água, a gente ia perder ela. (...) o Sebastião tava assim com uma aparência de pavor, os olhos abertos, a Fernanda estava com os olhinhos fechados, como tavam dormindo e a Clara também. Aí daquilo lá, eu saí de lá e não vi mais nada. A Prefeitura veio, éh ia sair do meu convênio o enterro, a Prefeitura se dispôs a cumprir com tudo isso e eu fiquei em choque, eu não conseguia pensar, eu não conseguia andar, eu não conseguia comer, nem tomar água, eu não conseguia fazer nada. Simplesmente, este tempo todo eu fiquei parada, parada assim como se você tomasse uma injeção de anestésico e parei. A outra parte de sofrimento é que eu teria que chegar no cemitério e deparar com a minha filha, com o meu marido, com a minha neta em um caixão.

JOÃO: não estava na casa na hora da enchente

... eu tava desempregado aí minha ex-mulher tava fazendo força para entrar num serviço lá no centro, eu peguei e fui buscar ela e passei no Poupa Tempo (...) começou a chover muito forte, muito forte, eu lembro que a gente tava com um pressentimento assim, vamos pra casa, vamos lá, vamos acelerar pra gente poder chegar lá e ver como estavam as coisas, pressentindo que estava acontecendo alguma coisa de ruim.(...) Peguei carona com um motoboy e fui até minha moto, peguei minha moto, peguei ela e tentei chegar aqui, eram mais ou menos umas três horas, eu levei do centro até aqui praticamente duas horas, que eram vários pontos de alagamento, a gente não conseguia passar por nenhum destes pontos, até que a gente conseguiu chegar por volta de cinco e dez, cinco e vinte. Mais ou menos dez minutos depois que tinha acontecido tudo. Cheguei aqui, vi um monte de carros, até pensei, tá acontecendo alguma coisa, né? Quando eu viro aqui e vejo tudo aquilo de água,( figura 10) eu fiquei, cheguei aqui no meu avô, toquei a campainha e perguntei: 
Figura 10 - Vista aérea da inundação às 17 h30 na rua Prof ${ }^{\mathrm{a}}$. Altimira de Souza Pinto

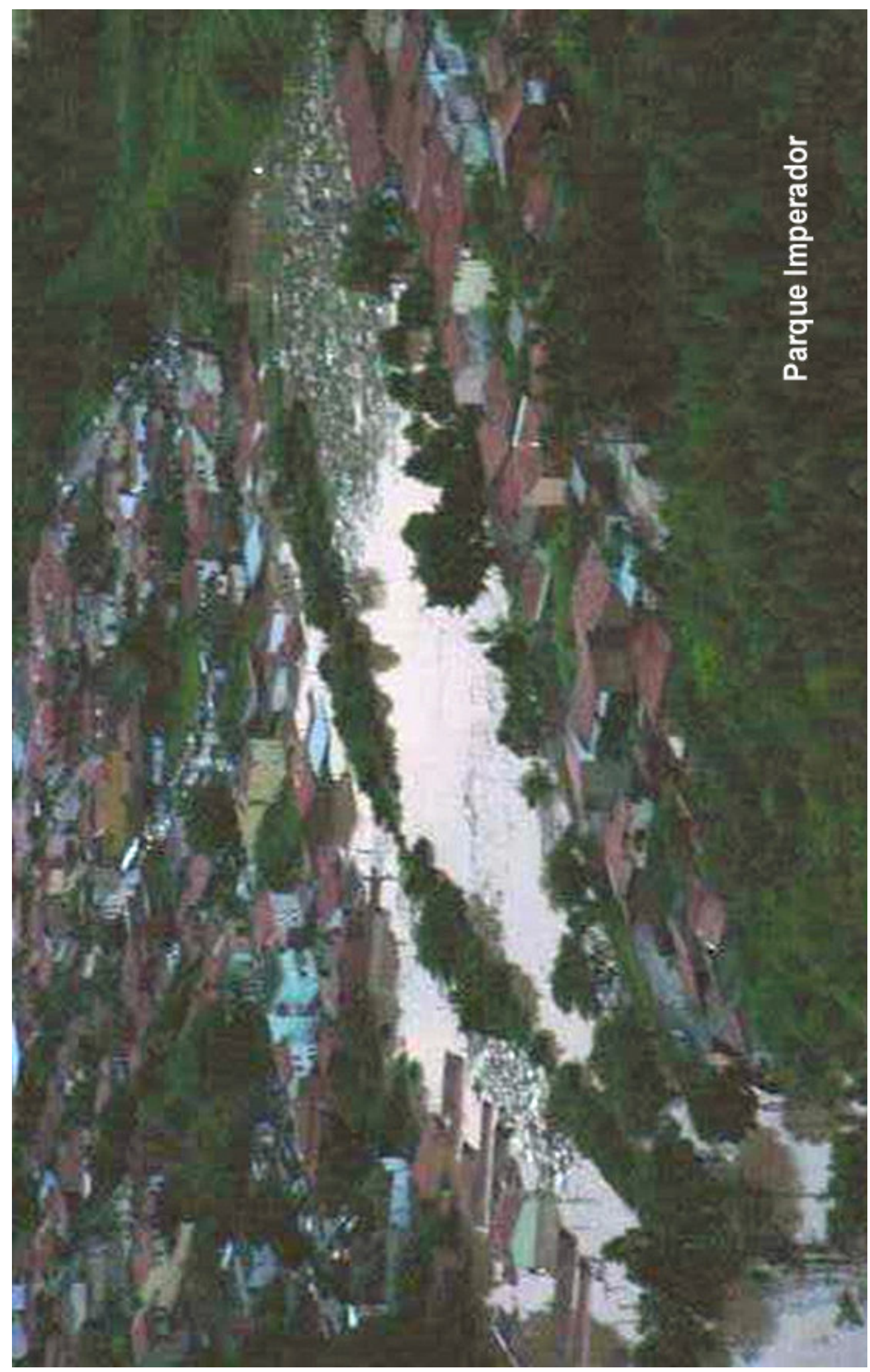


- Cadê meu pai? Cadê a Clara? Cadê a Fernanda? Até aí minha avó não sabia de nada, não estava suspeitando de nada. Ela falou: - Eles não estão aqui. Eu falei: - Você viu aí em baixo? Minha avó viu a inundação e começou a chorar. Eu peguei, e fiquei uns dois minutos assim, tipo em estado de choque, não me movia. Depois eu já tava todo molhado e saí correndo perguntando de casa em casa se eles estavam lá. ... fui lá ver como que tava a minha casa, se eu encontrava eles em volta, nisso eu deparei com o ... o pessoal da frente que trabalhava aqui no matinho, eles tavam em cima de casa ... em cima do telhado. ... Eles chegaram a nado ... chegaram lá, a primeira coisa que eles fizeram foi cortar a energia da casa, e depois começaram a arrebentar tudo para ver, quando ele arrebentou a geladeira subiu, porque ficou uma certa pressão dentro de casa, ... ele saiu. ... Aí nisso minha esposa entrou dentro do barco, subiu lá em cima, ela desmaiou, eu levei ela no hospital, tá, lá na Universidade. Quando a gente chegou aqui veio a notícia que eles estavam lá mesmo e não tinha nada a ser feito, que eles morreram. Eu falei: - Olha a minha mãe. Peguei minha exmulher e falei: - Vai dar uma volta, tenta se distrair um pouco, que eu fico aqui e tomo conta. Peguei e fui lá, sabia que os corpos estavam lá, e fui, mas ninguém queria deixar eu ver, falei: - Não, sou pai. Fui e vi. Realmente é uma cena que você nunca espera passar, você vê o seu pai, a sua irmã e sua filha lá. As duas pareciam que estavam dormindo, mas o meu pai tava com uma aparência que não dá para explicar, de pavor. Fiquei lá, depois fui embora, meu tio começou a tomar conta da papelada, do enterro.

Nestes dois relatos de mãe e filho, ambos vítimas da mesma dor, está claro e explícito a dimensão do drama e da perda. Entretanto, deve-se observar que ambos falam de um "pressentimento" de que algo de muito grave estava acontecendo e présentir pode ser entendido como o sentir antes e qual instância de nosso aparelho psíquico pode nos informar com antecedência de que iremos sofrer uma grande perda? Talvez informações sobre nosso próprio passado que ficam em nosso préconsciente ou nosso inconsciente, que impedidos de se manifestar em palavras possam se manifestar como sensações somáticas e descargas motoras e que ao ser 
constatado a concretização da ameaça, finalmente o sentir se encontra com a palavra e se articula na idéia de um conhecimento anterior não plenamente consciente.

\section{B. Premissas:}

i) familiaridade com os antecedentes das enchentes, informações locais e parecer técnico

\section{NEUZA:}

...Dizem, quem tava lá, que foi assim questão de três minutos, encheu tudo, a água não veio pelo córrego. O córrego, ele é um escoamento de água limpo, que vem lá de cima, escorre aquela água baixinha, tem uns dois metros de profundidade (o córrego corre no fundo de uma calha de 2 metros). Já houve uma enchente, em 96, justamente por causa desses tanques e que ninguém fez nada, passou, passaram um papel, uma borracha e acabou. Não! Não (sabia que podia encher o rio) porque lá em cima não tem rio, eles tem açude. Eu acho assim que nenhuma pessoa com sanidade mental boa ia abrir o açude para jogar água para cá, e esses açudes realmente tavam em condições de ficar lá. É o que você pensa, como todas as pessoas, porque é o mínimo de água, é uma aguinha corrente muito pouca, muito pouca. Então a gente não sabe, não pode acusar fulano, ou sicrano, ou beltrano, mas assim a gente tinha certeza que nada disso iria acontecer. Já morava aqui ...na outra enchente aqui em 1996 ..., mas naquela época o que subiu? Subiu um metro, dava para você sair ... nas casas. Saía, todo mundo saía.Mas a gente achava que nunca mais ia acontecer isso. ... Porque uma vez que já aconteceu, esse problema já seria solucionado ... Eu acreditava piamente, que alguém pudesse fazer alguma coisa para isso não acontecer de novo. Agora hoje, eu vou falar pra você que eu não tenho..., eu não poderia estar morando lá na casa de novo, eu não desço lá para baixo. Eu não posso te afirmar que isso não vai acontecer de novo, pode encher lá de novo e acontecer.

Parece que a informação sobre as enchentes anteriores e a possibilidade de ocorrência de novos acontecimentos deste tipo não eram conscientes para Neuza, embora tivesse conhecimento dos eventos passados, mas também responde com um pensamento reificado pela ideologia. 
$\underline{J O \tilde{A} O:}$

O córrego, eu moro aqui e já faz quatorze anos e nunca vi este córrego encher com chuva normal, chove, mas nunca chega a vazar para a rua. O quê que aconteceu nesta enchente foi ocasionada pela represa, porque o tanto de água que tinha, tinha em fio no dia, espantou, parecia até o fim do mundo. Se você visse em cinco minutos sua casa encher oito metros de altura de água, com sua família lá dentro, você ia falar, não é chuva não! Com certeza é a represa que estourou.... : Eu sabia que tinha uns (açudes) aqui para cima, mas nunca tive a noção que esses açudes poderiam causar tudo isso na minha vida. Eu ando tudo aqui e tal, às vezes a gente ia pescar com uns colegas meus, então a gente chegava a ver os açudes mas não tinha noção do perigo, não tinha noção que um dia ele podia estourar, vir tudo em cima e causar tudo isso, transtornos para todo mundo. ... É, houve uma enchente (em 1996), também foi razão destas represas só que não foi, foi um metro de água que subiu... já morava aqui .... Entrou água nas casas, segundo o (vizinho), eu acho que entrou um metro de água nas casas.

Parece que esta situação de saber e não fazer uso da informação é justamente do que se fala da incomunicabilidade do risco. Existem os açudes, já houve pelo menos mais uma outra enchente anterior que teve a ver com os açudes e esta informação fica isolada e não se articula de forma a produzir um conhecimento que possa subsidiar alguma ação de transformação do ambiente de forma a torná-lo mais favorável à sua sobrevivência.

ii) $\quad$ Percepção da ameaça de perda:

NEUZA:

E hoje eu falo pra você, eu tenho muita falta do meu marido, ele era companheiro, eu tinha, como que eu vou dizer? Eu tinha um amparo do Sebastião, se eu tivesse com algum problema, se estivesse doente, ele me cuidava, ele me ajudava, eu já não tenho o Sebastião mais de amparo. A Clara foi uma luz que Deus me deu, ela veio completar uma felicidade. Eu só tive um, um na barriga, eu tive a Fernanda, e pedi a Clara pra mim poder 
cuidar e passar tudo de novo, cuidar de um bebê, trocar, ir no posto, levar no médico, então era uma felicidade minha, a Clara foi uma felicidade muito grande. Tudo o que eu te falar não vai passar para você o que a Fernanda era para mim. A Fernanda veio pra mim, eu não conseguia engravidar, eu tinha perdido um bebê, a Fernanda veio pra mim como uma mão de Deus, e depois eu consegui ficar grávida do João, coisa que eu não ficava. Era uma criança linda, as duas. Eu choro de tristeza, por não ter mais, pela minha situação, porque ... eu sempre fui dona das minhas coisas, tocando a minha vidinha, dona do meu espaço, podiam falar: - ah, é um cacareco! Mas é meu né? Eu consegui isso com sacrifício, eu sempre falo isso que se você tiver um caixotinho de cebola, um copo de requeijão e uma florzinha no meio é sua, teu ambiente, teu espaço.

JOÂO:

A gente sente muito, pelo amor de Deus, a gente sente muito a falta da minha filha, do meu pai, da minha irmã, que família pra mim é tudo, agora só restou minha mãe.... Me separei ... já não vinha dando certo, ela discutia muito com a minha mãe, já não a aprovava, eu tava segurando mais por causa da minha filha, aconteceu isso, minha filha se foi... E também não ia dar certo ela aqui na casa do meu avô, tinha que ficar eu e minha mãe, porque eu não ia deixar minha mãe, não, para ir com ela. Eu falei: - Vou ficar aqui com minha mãe. Ela foi para a madrinha lá...

\section{iii) $\quad$ Percepção Da Mudança Interior}

\section{NEUZA:}

... Mudou porque eu fiquei descrente de tudo, eu não confio mais nas coisas, eu achava que isso nunca vai acontecer comigo e de repente você vê que está acontecendo com você, então eu não tenho confiança que isso não vá acontecer, mudou, mudou completamente a minha cabeça. Eu conseguia ser uma pessoa feliz, apesar de todas as lutas, ... Eu conseguia cantar, eu conseguia dançar com as meninas, ... hoje eu me limitei, uma mãe que não tem mais os filhos, que vive aquela vidinha assim vivida por viver. Trabalho, tenho ainda o João, tenho que dar apoio a ele, é meu único filho, minha vida 
agora é ele. Eu não tenho mais um objetivo assim, quer dizer, objetivo assim eu até tenho, igual ele te falou, eu tinha, eu sempre fui uma mãe muito mãe, você vê que eu cuidei da Fernanda com todos estes problemas.

Parece que esta mudança refere-se a uma desesperança, uma desilusão e uma mágoa como se tivesse sido traída pelos acontecimentos. Esta idéia de traição pode partir de uma ilusão onipotente de que os acontecimentos seguem a ordem dos desejos e não seu próprio curso, determinado pelo desenrolar de múltiplas variáveis cujo percurso mesmo que tenha um comportamento previsível é para nós impossível de perceber. Este ressentimento manifesto na desconfiança pode ser fruto de uma antiga ilusão de controle, como se a natureza (enchente) lhe houvesse pregado uma peça.

B.

C. Argumento:

i) A escolha do local de moradia antes do desastre:

\section{NEUZA:}

A gente tava morando no condomínio com meu pai, que eles moravam num condomínio aqui, mas depois a taxa ficou muito cara, então minha mãe comprou aqui. Eu fui e aluguei uma casa e fui morar, tá? Aqui no Parque Imperador. ... A casinha era nova, era boa, o aluguel era bom, eu conhecia o dono da casa, era cliente meu há muito tempo do (hipermercado), era muito bom. A gente viveu assim lá, um mês e quinze dias muito bem. A minha rua era a rua da felicidade porque todo mundo conversava, todo mundo saía do lado de fora, a gente sentava para conversar, era muito bom mesmo. Era cheia de árvores porque o córrego passava e era do outro lado da rua, então tinha árvores, tinha banquinho para poder sentar. As meninas andavam, a Fernanda andava comigo à noite, então era muito bom. Nós passamos quarenta e cinco dias numa boa, muito felizes.

JOÃO:

Desde sempre eu moro aqui, por isso quando eu precisei dos meus colegas, a maioria estava lá em cima de casa tentando me ajudar, tentando salvar, eles... 
então, todo mundo conhece a gente porque a gente é, tanto eu como minha mãe e meu pai, eram tudo pessoas simples, pessoas que não se importava de ser tão humilde assim, a gente queria viver bem um com o outro, assim a gente foi morando, já faz uns quatorze anos... ... A gente morou em três ou quatro casas aqui e foi para o Flamboyant um ano antes de acontecer e aí na virada do ano a gente veio.

ii) A decisão de (não) voltar para morar no mesmo lugar depois do desastre:

\section{NEUZA:}

Agora, hoje, eu vou falar pra você que eu não tenho..., eu poderia estar morando lá na casa de novo, eu não desço lá para baixo. Eu não posso te afirmar que isso não vai acontecer de novo, pode encher lá de novo e acontecer. ... Pelo que eu passei, eu tô bem assim que nem São Tomé, sabe? Tô assim que nem São Tomé, em hipótese nenhuma eu desço lá, quando eu tenho que chorar com saudade da minha filha eu vou para lá, eu sento lá, mas ir para lá nunca mais, eu acho que isso pode acontecer de novo.... Porque (mudou de opinião) então, justamente o que eu te falei, eu achei que antes em 96 teria se tomado uma providência. ..., porque há bastante órgãos imbuídos nisso, então eu achava realmente, os tanques tavam lá, eles não tinham como estourar, eles estavam seguros lá.

$\underline{J O \tilde{A} O:}$

Tentar reconstruir a vida, tentar, mas eu acho assim, eu e minha mãe a gente queremos ter a nossa casinha, a gente quer ter o nosso cantinho, porque você sabe que a casa dos outros não é a sua casa, então a gente pensa em ter o nosso cantinho e constituir a nossa vida. Porque hoje o que me sobrou foi minha moto que eu trabalho com ela, assim é a única coisa que restou pra gente, porque roupa, documentos que foram nossos, tudo se foi e a gente tá aqui na mesma, não aconteceu nada de novo dentro desse um ano que aconteceu isso daí, não mudou nada, a gente tem os mesmos problemas, a gente tenta resolver, a gente corre atrás, minha mãe trabalha, eu trabalho o dia inteiro

iii) A guisa de avaliação: 


\section{NEUZA:}

Não! Deixa eu te falar! Eu falo que eu fui só mãe do céu e mãe da Terra, eu ainda continuo sendo mãe da Fernanda lá no céu, eu continuo sendo a "babá" da Clara lá no céu, eu continuo sendo esposa do Sebastião lá no céu, eu não me deixo distante deles, eu me vejo assim, como se ainda há um contato meu e deles, eu não me sinto sozinha, é tristeza falar que eles morreram, acabou, pra mim não acabou, eu ainda me sinto mãe, vó. É lógico eu não tenho alguma coisa concreta, palpável que eu possa pegar na minha filha, eu choro, tem hora que eu quero pegar a Clara, a Fernanda no colo e não consigo, aí que me dá esse tédio todo. Eu chego lá no cemitério, essa semana eu fui, eu sei que ta lá, não mais uma matéria, mas o restinho deles. E eu chego lá e eu consigo ter paz, eu rezo muito, eu peço muito. ... eu acredito que a minha fé em Deus é o que tá fazendo superar até hoje, é muita fé, tem horas que eu falo assim pra Ele, eu acho que não tem ninguém melhor que Ele pra mim conversar. Eu falo: - Puxa porque Você fez isso? Na vida da gente tem tantas perdas, por quê essa perda que para mim era tudo? Por que eu perdi tudo? No começo eu achava assim, que Ele não tinha que me deixar aqui, que Ele tinha que me levar junto, porque eu não ia conseguir superar tudo isso. Eu acho que Ele me deixou aqui porque eu tenho que lutar por outras pessoas, fazer por outras pessoas, cuidar de outras crianças, não é mais a minha, porque a minha, agora, ela não precisa mais dos meus cuidados. Eu acho que, lá em cima, a Fernanda não tem mais uma deficiência, o espiritozinho dela está sem deficiência nenhuma. Tanto que eu sonho muito com a Fernanda, mas eu sonho com ela andando de bicicleta, eu sonho com ela conversando comigo, subindo escada, pulando muro. Que nós éramos muito crianças, eu na idade que eu estou era muito criança com ela, então eu sonho com ela assim.

È interessante assinalar o uso da palavra "lógico" feito por Neuza, como se ela reconhecesse para si própria a inconsistência em seu discurso, para poder continuar com sua avaliação da situação. Nesta está incluída uma explicação para a experiência traumática através de seu diálogo com Deus e definição de novos 
objetivos de vida (Neuza trabalha, atualmente, como voluntária em uma instituição para crianças deficientes). A introdução da palavra "lógico" em seu discurso the permite também abstrair do teste de realidade e prossegue em seu encontro através dos sonhos com a filha, o que parece reconfortá-la bastante. Parece que está em funcionamento o mecanismos psicológico da negação de um aspecto da realidade que é intensamente traumático para o sujeito. É como se a Neuza negasse a experiência da perda real e esta negação se estabelece justamente pela sua afirmação “É lógico eu não tenho alguma coisa concreta". Ou seja, em um plano de idéias há um reconhecimento do não lógico objetivo de sua racionalização e é justamente o que permite ao seu eu poder prosseguir e manter um intenso contato com sua filha, marido e neta, sem o sentimento angustiante da confusão alucinatória. A objetividade da análise e avaliação da ameaça, perda e risco sucumbe à manutenção do $e u$. 
4.3.2 FAMÍLIA 2: Entrevista com o casal nomeados Raul e Solange e com duas filhas nomeadas Mariana com 18 anos e Claudiana com 25 anos.

A. Descrição Do Fato: Esta família não estava em casa na hora da enchente:

RAUL: seu depoimento é dado enquanto mostra fotos do ocorrido em seu microcomputador.

.... A chuva parou por volta das dezesseis horas e cinqüenta minutos, segundo o depoimento das pessoas que moram nas partes altas do bairro, e... a água não havia atingido as casas até então, muito pelo contrário, ela havia atingido a rua em determinados pontos em que a rua é mais baixa, forma uns (poças) no meio da rua e já estava retornando ... já havia cessado o evento como desastre é ... ... natural, quando ocorreu a barragem da enchente, ocorrendo a barragem da enchente o arraste dos móveis, então quer dizer, a onda repentina cobrindo a casa, o arraste dos móveis obstruindo a vazão do duto, e por conseqüência retendo toda a água que ainda não havia escoado do restante da bacia. Aí então houve elevação e por conseqüência ficou assim obstruído por cinco hora, quando a água conseguiu romper o obstáculo (...). Na verdade, houveram duas desos ... desobstruções, a primeira desobstrução quando houve um.. a água cedeu alguns metros e obstruiu uma tubulação mais abaixo, aí permaneceu, permaneceu assim durante..., ou seja, a água estava acima do nível dos telhados e baixou cerca de um metro e meio no volume geral, que era muita área inundada, baixou um metro e meio que é muita água, é.. equilibrando do outro lado do barranco que está ali mas obstruindo um pouco mais abaixo. ... E aí então, depois de bastante tempo, por volta das quase nove horas da noite, a água conseguiu romper também a obstrução mais abaixo. ${ }^{20}$ A pressão da água .... os tubos que estavam obstruídos pelos móveis, não é? eles estavam há pelo menos uns quatro metros, de quatro a cinco metros de profundidade... É.. os bombeiros sequer conseguiam se deslocar com a lancha na água, porque a quantidade de

${ }^{20} \mathrm{O}$ vale onde se localizam estas casas é limitado no sentido longitudinal por uma elevação a montante do córrego São Quirino e a jusante primeiro pela "barranca" da linha férrea, uma elevação com cerca de 4 metros acima do leito da rua. Após 1996, foi ampliado o escoamento do córrego por 
aguapés das represas era muito grande, o que retinha a hélice. (As pessoas) foram resgatadas, a grande maioria pelo helicóptero.... Na verdade, já bem tarde do dia nós conseguimos entrar aqui em casa com água ainda no meio do terreno, pulamos por cima, eram umas três (casas) ... Não, na realidade não estava aqui no dia em que encheu de água, eu cheguei até aqui, na verdade estava até bastante preocupado porque neste horário costuma estar aqui minha filha caçula, de dezenove anos, ela trabalhava neste período, ela trabalhava até umas quinze horas e geralmente das quinze e vinte em diante ela costuma estar em casa, e então, em função disso tudo nós chegamos às dezessete horas e quarenta mais ou menos aqui e já estava instalada a situação. Nós não sabíamos se minha filha estava em casa ou não, entendeu ? ?... e ficamos preocupados com o cachorro ... é nós não o encontrávamos de forma nenhuma, depois nós descobrimos que a pressão da água deve ter partido uma janela que fica encostada .... e o cachorro deve ter sido trazido porque a onda de cheia foi muito forte, tudo isso encheu com uns dez minutos, nem dez minutos, entendeu? Pelos depoimentos das pessoas que estavam nas casas e que de súbito ficaram submersas, entendeu ... Aquele portão nosso, que é ... muito reforçado, portão alto ele quando ficou preso ao cadeado do batente, mas ele foi quebrado nos pontos de solda e torceu de forma que a água entrasse com toda a violência, quer dizer, é a força da onda de água arrancou o portão, mas também não tem do que se queixar porque pôs abaixo uma casa toda, éh quebrou outra no nível da lajota, quebrou outra no nível da meia casa, que a pressão da água entrando, entendeu? e a onda de choque derrubou muros...

(descrevendo os moradores da casa) Eu, a Solange, a minha filha mais velha a Claudiana, que perdeu boa parte do seu enxoval de casamento, .... que estava aqui dentro, ... a minha filha Mariana, que nós temíamos que pudesse estar aqui dentro no momento, o(...) pequenininho, (filho com 5 anos) ...cinco pessoas na verdade. Na realidade eu tive muito problema para chegar até à Universidade, onde (Solange) estava e onde estava o pequeno, porque os acessos estavam bastante prejudicados, porque realmente foi uma 
chuva muito forte entendeu? Tem chuvas que obstruíam a passagem não é? Éh.... aí quando eu já estava saindo da Universidade eu recebi um telefonema de um morador, que mora na parte alta do bairro, no meu celular, e ele dizia que, graças a Deus, ele conseguia falar comigo, porque ele temia que eu estivesse em casa, que a casa estava em baixo d'água. Então eu soube dessa forma, como a faculdade é bem próxima, não é? Eu cheguei muito rápido, cheguei dessa ligação em dez minutos... Na verdade não, nós só fomos ter contato com a filha mais velha no fim do dia, inclusive o filho (casado) também, não é? Porque aí começou ... depois de passado o tormento, ele também teve problemas na casa dele... e entrou muita água pelo telhado da casa, que era recém alugada e que não era um bom telhado, então lá, apesar de grande o impacto da entrada de água com uma criança recém nascida, éh.. não se comparava com essa situação não é?... Aí eu já tinha visto o caos instalado, não é? Digamos assim a impossibilidade de ajudar meu filho ...

\section{MARIANA}

... porque minha amiga, ela tinha saído de casa nadando, então eu a encontrei toda suja de barro, e a primeira coisa que ela fez foi me abraçar e dizer: - Perdi tudo!

Então, se chegou na casa dela, eu imaginei o quê que não aconteceu na minha casa, eu não consegui falar com eles, eu não sabia onde eles estavam, eu fiquei com medo deles estarem em casa, e aí eu me senti impotente e eu queria vim aqui, mas eu também não sei nadar e não sabia como vir aqui, aquela coisa de não conseguir fazer nada, então é uma sensação muito horrível, de não saber o que fazer, não poder ajudar e não saber como ajudar. Não tinha uma palavra para dizer o que a gente sentiu naquele momento, a gente teve que abraçar as pessoas, tinha gente já molhada que já estava na chuva, tinha gente que tinha saído da água, que veio e não conseguiu pegar nada. Eu tinha documentos comigo, ela (a amiga) não conseguiu salvar nada, nem dinheiro, nem documentos, ela estava com a roupa do corpo, e molhada e suj, ainda isso! ... E eu acredito que essa sensação perdurou por bastante tempo na vida dela, foi um período bem difícil. 
Deve-se assinalar no trecho grifado a percepção da ausência de palavras como evidência do trauma psíquico onde o indivíduo não encontra, ou perde as palavras que um dia teve para expressar a intensidade de seu desamparo e precisa ser amparado pelos abraços. O processo psicológico subjacente é a experiência do desamparo que é de difícil simbolização devido a intensidade da ameaça de aniquilamento. $\mathrm{O} e u$ do sujeito em defesa de sua integridade desencadeia um processo de afastamento da realidade externa adversa de formas diversas, porém complementares e peculiares a intensidade da experiência sentida. Quanto esta ameaça de aniquilamento assinalada no depoimento de Mariana, verifica-se que por sua radicalidade e possibilidade concreta da morte remete-se a um período de constituição deste eu, anterior a aquisição do universo simbólico e a manifestação de emoções desta ordem terão necessariamente que processar-se principalmente, de forma somática (Freud, 1915, 1925). Usando uma outra linguagem poderia considerar que a representação coisa se impõe sobre a representação palavra e o abraçar-se representa concretamente este juntar os pedaços frente a ameaça de fragmentação, estilhaçamento e destruição. (Freud, 1915)

\section{SOLANGE:}

Essa situação sobre a Mariana foi um pico ... tava tudo transtornadas as linhas telefônicas, consegui ligar no celular dela, a gente tava quase chegando aqui, a gente estava ali beirando a estrada perto do (hipermercado), foi a hora que eu consegui conversar com ela, e a gente tava realmente muito aflito por esse momento, e a hora que a gente conseguiu falar com ela, ela estava chorando muito, falei para ela: - Filha já, já nós tamo aí! Daqui a pouquinho nós tamos aí! A gente chegou ela veio, abraçou a gente, assim, sabe? E de repente eu olhei e vi que tudo o que a gente tinha de valor tava do lado de cá da água. Foi um detalhe importante pra mim. Eu olhei, eu pude abraçar minha filha, olhei para ele, olhei para o meu pequeno, e olhei para mim vendo que a outra tava lá no serviço. Falei: - Olha, o que eu realmente tenho tá tudo do lado de cá da água, então nada do que ficou aqui debaixo d'água teve....eu acho que ele compartilhou deste meu 
sentimento. A gente teve a oportunidade de conversar muito sobre isso. De repente tudo o que a gente tinha de valor tava com a gente do lado de lá.

i) Relato da entrada na casa:

RAUL:

A parte elétrica, todos os fios, muitos aparelhos ficam ligados em stand-by, secretárias eletrônicas, televisões, videocassetes, é, enfim, eles ficam ligados em stand-by. Quando nós chegamos aqui, quando eu entrei, na madrugada, eu encontrei a estrutura de metal da porta eletrificada, os disjuntores não desligaram, durante o tempo todo que ficou submerso eles entenderam o curto circuito como consumo, dado que o que fez a intromissão foi água, eles entenderam como consumo. E alguns fios começaram a colar, a partir das tomadas, para dentro das tubulações. Então nós precisamos trocar a parte elétrica toda, entendeu? Inclusive o medidor, que foi recolhido depois sem substituição.

(Entrada na casa) umas duas e meia da manhã... eu passei por cima do telhado para poder descer em frente à casa, porque no meio do terreno ainda tinha água, água não havia escoado porque o desnível do terreno é para frente, não é? Então eu subi pela casa pelo terreno do vizinho, desci por cima do telhado em frente à casa, quando eu cheguei, vi a estrutura eletrificada, não tinha como chegar até o relógio de luz, que ainda estava debaixo d'água, não é? Como minha casa está a dois metros de diferença do nível da rua, então, a rua ainda estava submersa pelo menos um metro. A água chegava até o meio do meu terreno. ...

Também! Também! tinha o risco de você ser eletrocutado? ... eu trabalhei como eletrotécnico, então, eu sabia dos riscos que estava correndo, não é? Eu tomei algumas precauções, consegui abrir a porta, entramos, entendeu? Eu vi um vulto, era o meu cachorro, que tinha sido jogado para dentro da casa, o pastor, pela situação que encontramos os móveis, ele deve ter ficado nadando durante as cinco horas que permaneceu ... ele estava com as pernas moles, não conseguia parar em pé. 
Figura 11 - Vista da rua na madrugada de 18/02/03

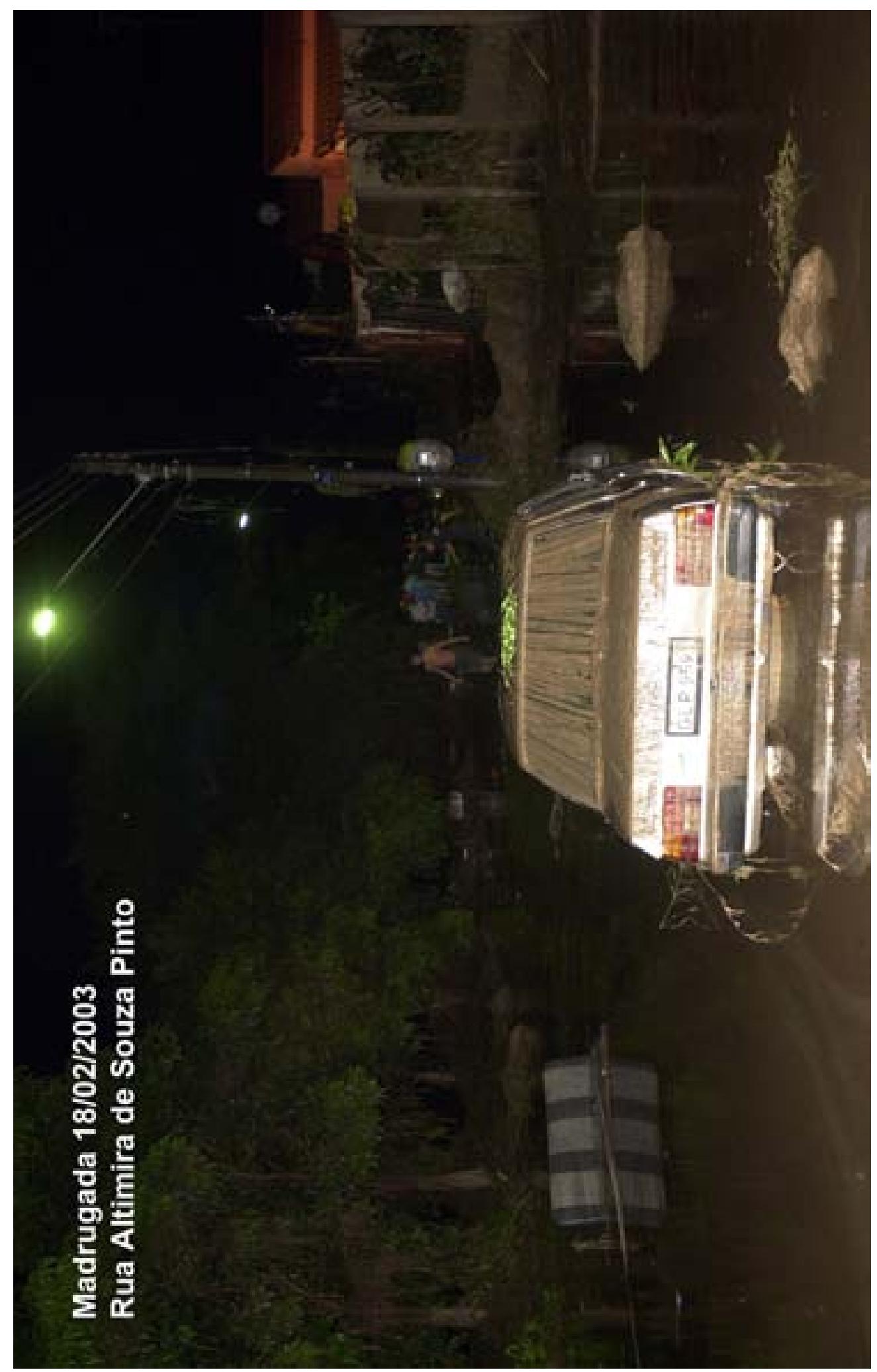


... já que eu não conseguia chegar nas coisas, eu ouvia barulho, alguma coisa em curto em um dos quartos zumbia, ainda estava ligado na corrente elétrica, fazia um zumbido muito alto...bom.... a cena era "dantesca" , não havia muito o que fazer naquela hora, não daria para pegar coisa alguma, então eu não peguei nada. Eu virei de costas, procurei acomodar o cachorro ... nessa espuma de borracha, num canto que eu abri em frente à porta, o instalei pertinho da porta para vir buscá-lo depois porque não havia como tirá-lo daqui. Passar com ele por cima do telhado, por dentro da casa, eu não daria conta

\section{SOLANGE:}

... na hora que eu entrei aqui...com grande dificuldade, porque ainda tinha muito lodo, né? Ele (marido) já tinha inclusive dado uma boa melhorada na condição, porque não dava para entrar. Quando eles entraram aqui, ele, meu filho, o namorado da minha filha mais nova e o irmão dele. Entraram aqui, né? e inclusive porque a aflição da gente era o cachorro e quê que ainda estava em pé, né?

Na figura 12, pode-se observar o interior da residência após a enchente, retratando o cenário que a família se deparou ao entrar em casa. . 
Figura 12 - Interior da residência com a marca da altura da enchente

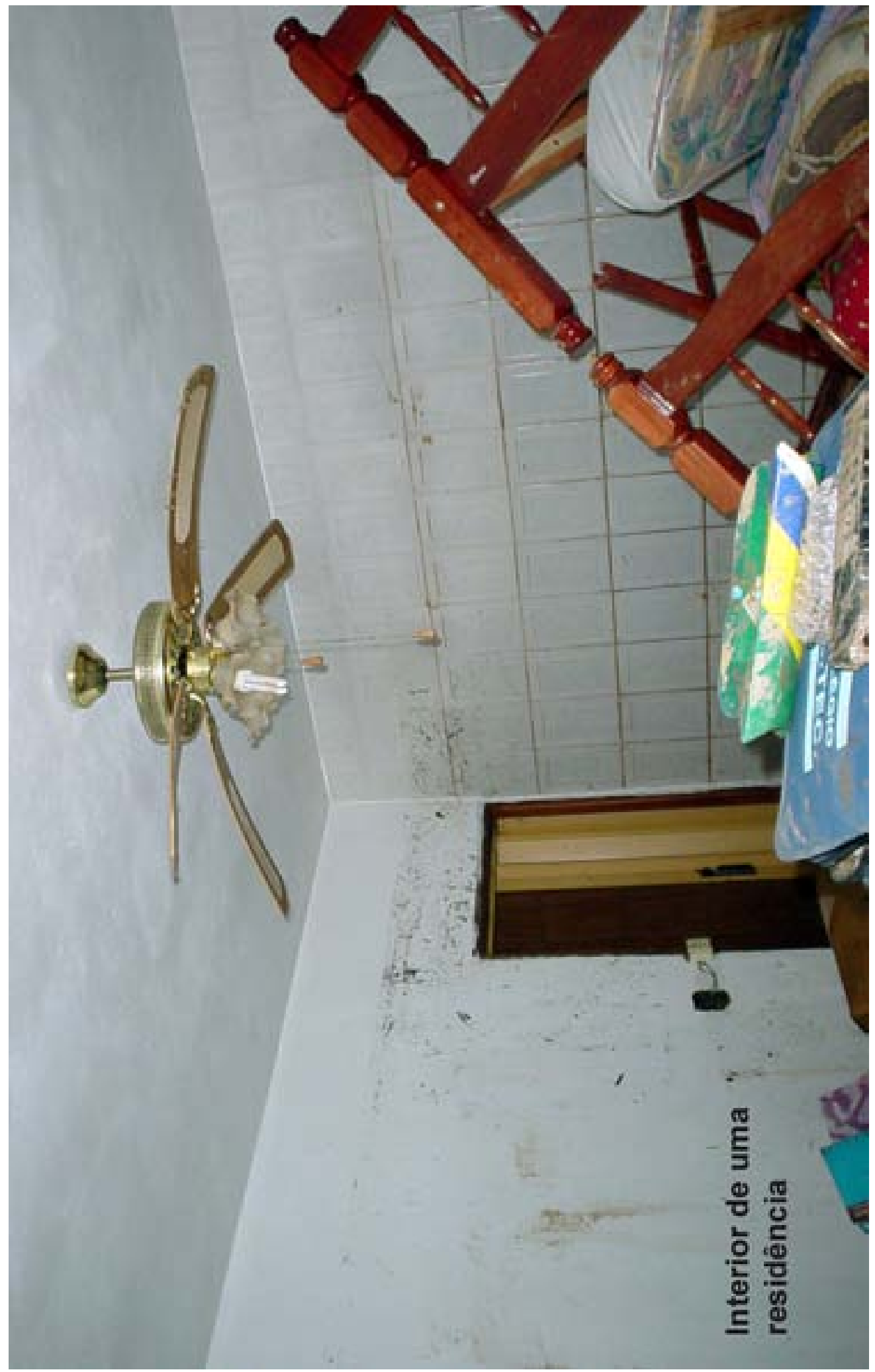




\section{B. Premissas}

i) Familiaridade com os Antecedentes das Enchentes, Informações Locais e Parecer Técnico:

RAUL:

... eu imediatamente, pela própria história, sou o morador mais antigo desta rua, uns dos mais antigos na verdade deste bairro, quando cheguei aqui não havia nenhuma casa naquela parte alta do lado esquerdo para baixo da escola, e só havia casas populares na entrada do bairro e umas três casas remanescentes da colônia da fazenda na rua de trás. De forma que eu conheço essa situação como ninguém em termos de histórico e eu sabia que havia o comprometimento das barragens mais acima, e que não poderia ter sido ocasionado de outra forma, então, êh, eu comecei a imaginar como demonstrar isso, tirar todos os materiais que haviam sido êh, motivo de, motivo de ações anteriores, de tomadas de posição anteriores, solicitações de providências anteriores, junto à defesa civil, junto à própria promotoria do meio ambiente quando em se entrou com a representação, eu entrei com a representação, mais um abaixo assinado de todos os moradores reiterando a minha representação, e a promotoria do meio ambiente acatou a denúncia e começou a pressionar o município ... 95. E eu, todos estes documentos estavam aqui, então eu tinha como demonstrar isso. Houve sim, é... coisas artificiais que haviam se rompido para poder causar o efeito como causou , entendeu? Porque ... a cheia, ela vem enchendo, vem enchendo devagar, eu moro aqui há muito tempo, vi isso acontecer muitas vezes, a água chegava, vinha subindo, subindo, subindo, êh ... quero salientar que aonde está minha casa, eu moro aqui desde 86 para 87, acredito que pelo menos eu tenho os documentos mas, quase vinte anos com certeza, e nunca havia entrado água na minha casa por motivo de enchente. A água chegou até o rodapé da porta da minha entrada, na maior cheia que nós tivemos aqui e não entrou para dentro, entendeu? Mas mesmo assim nós tomamos providências, porque eu sabia que isso poderia ficar mais sério, como ficou não é. 
Então nós pedimos através da promotoria e eles forçaram o município a tomar providências, foi quando o município em (19)96 concluiu uma obra que havia iniciado anteriormente e deixou como estava, deixou pela metade. Era um único tubo passando por baixo da barranca toda, eles vieram, começaram, implantaram mais dois tubos, mas só passaram a rua e deixaram a boca parada na barranca do (córrego) Anhumas. . Então por força da pressão da Promotoria eles terminaram de fazer o resto da obra, em 96, nós estivemos, éh ... eu fui novamente no Fórum e pedi para que cessassem o trabalho visto que a obra tinha sido levada a tempo. Se eu tivesse imaginado que nós pudéssemos ter este problema, teria deixado que eles continuassem investigando, porque afinal de contas, não é tão seguro quanto nós imaginávamos, não é.

\section{i) Percepção Da Ameaça e Perdas}

RAUL:

Com certeza, com certeza, a aflição maior que pode existir era com relação a minha filha, e realmente quando nós a encontramos na rua de trás, exatamente na frente de onde agente mora, .... foi um motivo de bastante emoção e nós realmente foi, neste primeiro dia foi o único momento que eu chorei, então eu acho que isso é importante ser ressaltado porque eu não voltei a chorar se não depois de muito tempo transcorrido. Sou uma pessoa bastante prática. .... A água foi até em cima, nós temos depois aqui as marcas na casa da vizinha que não foi pintada, eu posso demonstrar para você entender que tudo, tudo isso aqui foi submerso, entendeu? Perdi dois computadores, é impressoras, scanners,(figura 13) enfim, tudo, tudo que nós temos aqui, tudo que nós temos aqui é novo. Tudo, tudo.. a roupa, a maioria delas doada, é inclusive----se tem uma coisa que já não era orgulhoso, não é? apesar de ter uma postura, as vezes, que pode levar a essa conclusão, eu realmente não sou orgulhoso, mas depois do dia dezessete, eu posso te dizer que se havia algum resquício de orgulho, ele foi embora, então não me sinto constrangido em dizer, sabe? que bem pouco que nós tínhamos em termos de roupas, se salvou. 
Figura 13 - Vista da situação em que foram encontrados os equipamentos mencionados

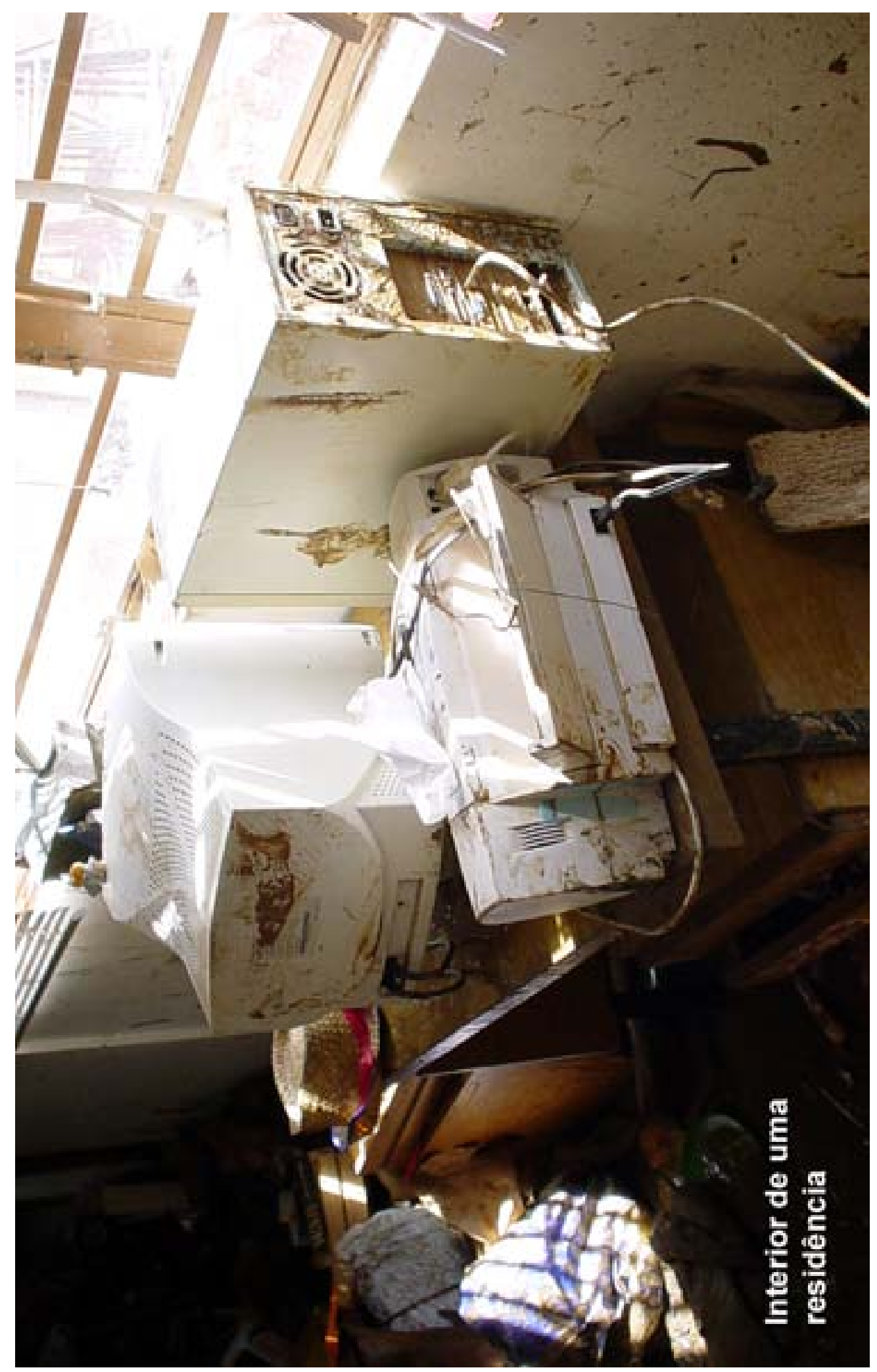


Desci eu, meu filho e o namorado da minha filha mais nova, ... inclusive as roupas que eu levei para trocar eram dele. Porque eu saí daqui todo sujo de lama. Ele tinha uma casa para ir e eu já não tinha mais. (risos). Então ele se preocupou em me providenciar uma muda de roupa, não é? Saímos daqui, uma parte da minha família já havia ido para a casa da minha sogra, no Taquaral, e nós fomos para a casa da minha mãe, que nenhuma das duas casas estava preparada para receber um número tão grande de pessoas de uma vez só, não havia acomodações para todos. Nós ficamos divididos durante um tempo. Eu comentei contigo numa conversa anterior, eu descobri que é horrível ficar com a família dividida. Eu ... a força da nossa união, sabe? Tem um componente muito importante.

\section{SOLANGE}

... como eu disse é não foi assim muito difícil a acomodação em si, porque na hora que nós passamos na casa da minha mãe, já era bem tarde até, minha família já tinha sabido e a casa da minha mãe já tava cheia de coisa. Eu já tinha roupa para trocar quando cheguei na casa da minha mãe, já tinha uma muda de roupa para tomar banho e trocar de roupa. Então, aquela coisa mais difícil que a gente até poderia ter passado, digamos assim, nós nem sentimos, aquele momento daquela noite, ficamos sem nada mas ao mesmo tempo não ficamos sem nada, tinha até muda de roupa para a gente tomar um banho, como ficar limpo, né?.........

Eu tava comentando estes dias das enchentes em São Paulo, hoje enche de água eles dizem: - Ah! perdi tudo! Amanhã enche de água eles falam : - Perdi tudo! De novo, então não tinha perdido tudo! Se ele já não tinha nada de ontem como que recuperou para perder novamente. Nós perdemos tudo! Se chovesse no outro dia, a gente ia era agradecer porque ia ajudar a lavar, porque nem água para lavar tinha. Não choveu um dia, não choveu no outro, fez sol e o barro secou.

\section{MARIANA}

... Foi um reflexo, porque eu cresci com ela, ela é como uma irmã para mim, e no momento que ela me abraçou ela passou tudo isso para mim, tive que ser 
muito forte para ela nesse momento, porque ela só tem irmão que também não estava preparado para aquilo, e a mãe dela teve que vir, cuidar da casa. Quem teve que ser forte para ela, naquele momento foi eu, porque ela não tinha ninguém perto para ser forte para ela. Tive, digamos que, sustentar muito todos aqueles problemas naquele momento para ela, além do que eu tinha que sustentar para a gente. Eu acho que se eu estivesse aqui eu não ia suportar daquele jeito, mesmo assim foi um reflexo muito grande, o que ela estava sentindo passou muito para mim, foi como se, de certa forma, eu estivesse aqui.

\section{CLAUDIANA}

.... meu enxoval estava na casa da minha avó, mas eu tinha as minhas roupas, muito livro, muita apostila, coisa da faculdade, tinha muita coisa guardada, entendeu? Mas não sei se era por causa disso que eu queria entrar, sinceramente eu não sei. No dia que a gente veio tirar as coisas daqui de dentro do meu quarto, aquele dia eu sofri bastante, aquele dia eu sofri muito, sofri porque eu sabia que eu estava fazendo um esforço físico, psicológico para tirar uma coisa que ia pro lixo, entendeu?

\section{ii) Percepção do risco:}

RAUL:

Não ... não era um risco calculado, porque veja bem, .... até 1995, com todas as cheias que nós tivemos, algumas delas, inclusive, logo que nós chegamos em 87, entendeu? É, algumas casas mais no final da rua tiveram um índice alto, de água muito alta, entendeu? Mas a posição da minha casa, eu não tenho essa topografia, mas como diversas empresas fizeram, talvez você até consiga, você vai ver que nunca entrou água na minha casa por esse motivo, entendeu? A minha casa está bastante elevada com relação ao eixo da rua, eu tenho um metro e oitenta de diferença deste ponto que nós estamos pisando com relação ao portão da minha casa.(figura 14) Ele tem mais aí, uns pelo menos quarenta centímetros de diferença da rua. Então, nós estamos há dois metros de diferença de altura do eixo da rua. Imagine que, para que 
Figura 14 - Frente da residência de Raul com o portão fora do lugar no dia seguinte

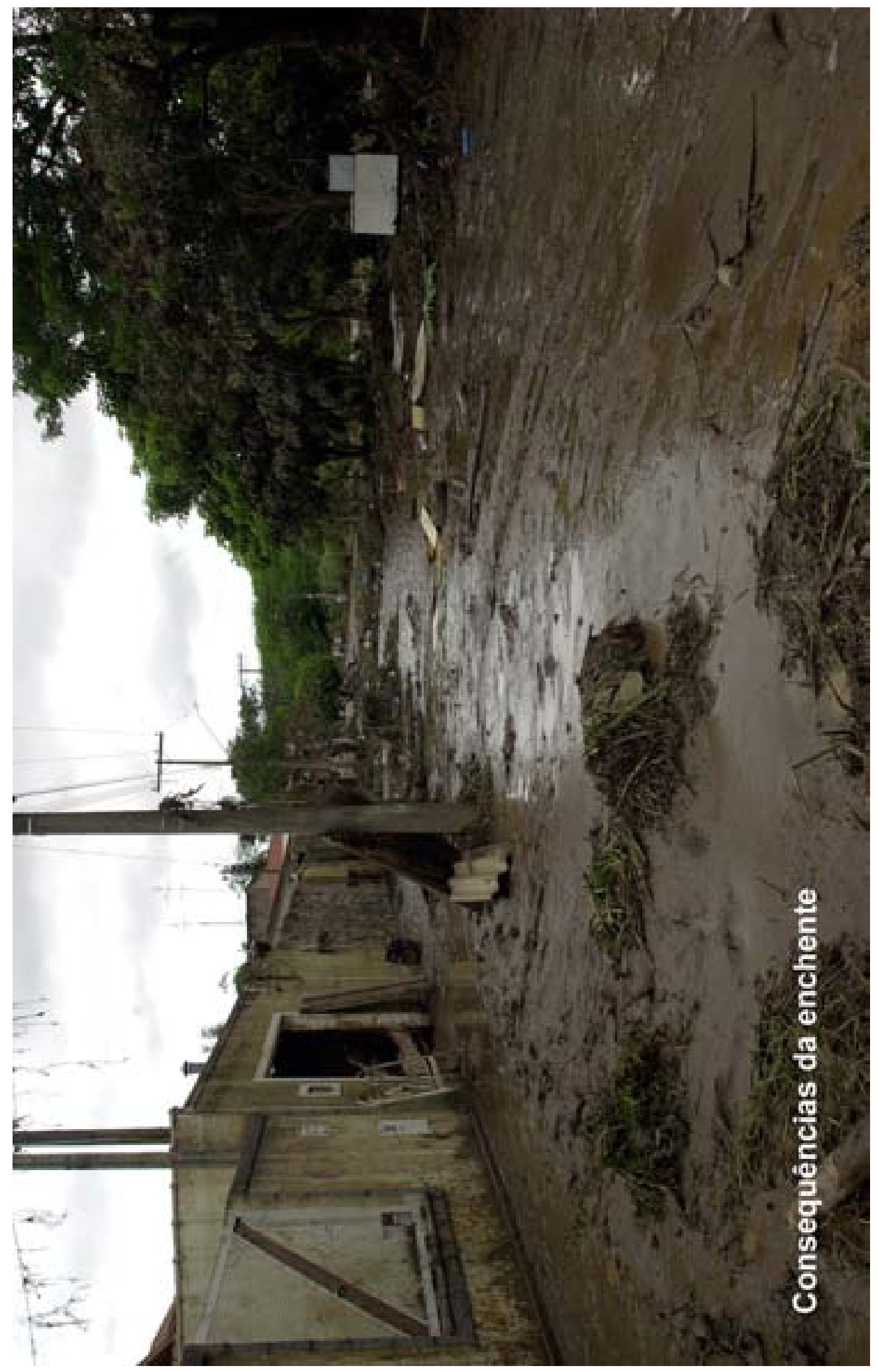


a água suba dois metros acima do eixo da rua, que tipo de evento nós precisaríamos para que a água começasse a entrar na minha casa? Então, mesmo em 95 quando eu entrei com a representação, de certa forma, é porque o meu coração ficava apertado porque eu tinha meus próprios problemas, eu recebia água de enxugo da rua de trás, eles tinham ... um declive muito acentuado, e não havendo essa construção, aqui mais próximo da minha casa, toda a água que descia de enxugo batia na parede do fundo, então entrava água pela parede do fundo, o reboco não dava conta de reter a água que, que se acumulava ali. Então eu tinha meus próprios problemas mas eu via o pessoal andando com água na cintura do meio da rua para frente e as casas lá da onde atingiu pessoas em 96, entendeu? Ficava com um metro, um metro e vinte de água dentro de casa. Então eu busquei, e outro, querendo ou não, sim eu não posso mentir, havia sim um risco, não é? Imagine uma moita de bambu, alta, muito grande rodando e tampando o único tubo que passa água? Isto era um risco sem dúvida, isso era um risco, sendo a única saída de água. A água se elevaria até que conseguisse retirar a obstrução, isso.... uma questão óbvia, um tubo de dois metros e meio de diâmetro.

Eu me preocupava, (quando começava a chover) mas eu sabia que o que realmente causava as enchentes era que, as barragens, inclusive eu andei muitas vezes subindo o curso dos rios, pode ... eu agora estou até admitindo que não fiz uma coisa muito correta, uma vez que a maioria das propriedades são particulares, mas eu conhecia muito bem o curso do rio, até por uma curiosidade natural, eu queria saber o que havia daí para cima, não só pelo curso do rio, como também pelas estradas, as vicinais que eu já conhecia muito bem, andei por essas estradas, andei a cavalo, andei de moto, andei de carro, andei a pé, andei de todas as formas, entendeu? Então conhecia bastante das intervenções que haviam lá para cima. Eles trabalhavam com elas sempre bem cheias, uma vez que começava a chover, então eles tinham que receber a água da chuva, então eles tiravam a..., abriam este excesso de água do rio cheio e nós precisávamos, êh ... ficar aqui em baixo não só com a água do enxugo da chuva em si, mas com o excesso de água que eles haviam prendido lá em cima para que a água ficasse até a borda, para que 
ficasse bem bonito, bem cheio nos açudes, entendeu? Isso nós denunciávamos com freqüência à Defesa Civil. Por força de intensas reclamações no ano de 96, êh..., promoveram um documento, através do (DAEE), o Departamento do Estado que regulamenta isso, dizendo da fiscalização e das obras de regulagem aí para cima, que nós depois conseguimos recuperar. Tiramos ainda úmido, retirei o documento com muito cuidado, descolando um do outro, deixei secar no sol, fiz uma fotocópia dentro de uma empresa longe daqui, é de alguns conhecidos, com recursos para poder éh recuperar o conteúdo do documento, porque lá haviam dados interessantes, não é? Como por exemplo, o fato de que era já conhecida nossa situação de risco aqui...

\section{SOLANGE}

(preocupação quando chove) Que nem agora. Que nem agora.

\section{ii) $\quad$ Percepção Da Mudança Interior}

$R A U L$

Eu queria retornar um pouquinho, eu queria falar da questão de olhar para cima e de olhar para a lama. A diferença que isso faz, sabe? Eu entendi logo que havia um grande aspecto nisso tudo. Havia um aspecto de muito trabalho de reconstrução, de colocar a nossa situação de moradia de novo, de alguma forma, mas sabia que nós não ficaríamos desamparados, não só por causa de nossos parentes mas, principalmente, por causa de Deus. Aquele que provê todas as coisas, afinal de contas nós nascemos pelados não é? Então olhando neste contexto, nós estávamos vestidos, nos havia sobrado nosso meio de transporte, tínhamos o telefone pendurado na cintura. Eu diria que agente estava até privilegiado (risos). Mas o que me preocupou muito, eu comecei a olhar as pessoas e era uma cena de desespero geral, entendeu? Por outras experiências eu sei que as pessoas procuram olhar muito mais o problema, do que para a possível solução. Eu comecei a me preocupar com isso. Algumas dessas pessoas eu conhecia, como eu disse eu sou o pioneiro dessa rua, profundamente, de longa data, e outras não mas eu vi que a situação de todas era muito parecida, muitas pessoas derrotadas, olhando para baixo, de ombro caído, de queixo baixo. Isso não é construtivo, acho que quando a gente está dentro do buraco, só existe uma forma de tentar sair dele, que é 
olhando para cima. Em virtude desta disposição, eu acabei, não que eu tenha querido que fosse assim, mas acabou sendo assim, eu acabei me tornando um líder sem querer, quando eu vi as pessoas já estavam, no mesmo dia, no dia dezoito, eu acordei um repórter e disse que nós precisaríamos muito dele. .... Eu costumo dizer para as pessoas que se eu quiser achar um milagre, eu não procuro longe, eu olho no espelho. Eu me considero um milagre.

\section{MARIANA}

Trauma! As pessoas ficam com este trauma. Elas não procuram, tem gente que não procura tratamento, ela fica com isso, diz que não e quando chove, a pessoa entra em pânico. Ela fica desesperada. ... mudei ... mais responsabilidade, você tem uma noção maior de vida, de ver as dificuldades das outras pessoas, você vê que muito do que você achava que era tão importante para você, não era tão importante, você dá mais valor às pessoas, assim como as pessoas dão mais valor a você. Isso toca em você, faz você mudar para o mundo, faz você mudar em tudo, não é só em uma área da vida da pessoa, é em todas as áreas, faz um pouco.

Nos trechos acima, recortados dos depoimentos desta família, encontram-se as premissas que podem orientar na decisão bastante crucial de o quanto se estaria disposto a tolerar de mudanças em seus modo de vida, em decorrência do fato traumático. Recorta-se o relato da percepção da extensão da perda não apenas de bens materiais, mas também de uma história identitária do sujeito, e talvez o relato mais dramático neste sentido seja o de Mariana, que fala da amiga e acaba por se colocar neste lugar e reconhecer que poderia estar falando dela. Adicionalmente, verifica-se que havia, pelo menos por parte de Raul, um conhecimento anterior bem elaborado sobre a situação de risco em que vivia e pode-se considerar, dado os depoimentos, que esta idéia tenha sido compartilhada com seus familiares, até pelas ações que motivaram, como os recursos ao DAEE e à promotoria de meio ambiente. Portanto, todos tinham conhecimento dos riscos até por experiências anteriores e uma antevisão de Raul sobre as enchentes muito aproximada do que realmente aconteceu em 17 de janeiro de 2003. Fica assim a aparente incógnita de porque estas 
pessoas agem sem memória e, portanto, sem futuro, que se tentará responder mais adiante.

\section{B. Argumentos:}

i) $\quad$ A Escolha Do Local De Moradia Antes Do Desastre

... na verdade eu não decidi, eu pra chegar a ir morar aqui, quando eu cheguei aqui nós tínhamos um esqueleto de casa em pé, nós tínhamos as paredes de tijolo nus em pé, desta parede para trás, o telhado era de telhas Brasilit, aquelas de mais baixa qualidade, bem fininha, com muitos furos e em trinta dias antes de vir morar para cá nós trabalhamos aqui até cerca de duas, três horas da madrugada para podermos entrar. ... Acontece o seguinte. O dono dessa propriedade, (bem) quando meu pai chegou numa situação ele foi morar no Novo Cambuí, quando eu tinha seis anos. Eu tenho quarenta e seis, portanto, há quarenta anos atrás foi morar no Novo Cambuí, Chácara da Barra, ali bem atrás do Correio Popular, e o senhor dono desta casa, na verdade era do filho que faleceu, o pai ficou com a propriedade, e ele morava abaixo da casa do meu pai, entendeu? E naquela época não havia uma rede de água que abastecesse a rua onde meu pai morava, então meu pai implantou uma rede de água por conta própria, quer dizer, eu imagino a situação do meu pai também chegando para morar, levando todos os cômodos, eu me lembro bem, eu era pequeno, puxou a rede de água, que não havia rede de água na rua, de longe, comprou muitas barras de cano de ferro, para poder fazer esse cano, e um belo dia ele abriu a torneira e não saía água, ele começou a correr esse cano e achou uma ligação e essa ligação descia para a rua de baixo, e tinha uma casa nova, e estavam usando da água da rede do meu pai. E o meu pai, chegando lá, ele encontrou o pessoal morando com a água ligada daquela rede, entendeu? E olhou para o pessoal e falou: - Olha! Nós vamos fazer o seguinte, aquela rede lá em cima é minha, eu não vou impedir vocês que usem a água, eu só vou fazer o seguinte, eu vou combinar um horário com vocês. Então, não dizendo que não fez menção em momento nenhum, mas é inevitável lembrar que o meu pai estendeu a mão para este homem, entendeu? E este homem estendeu a mão para mim. Eu acho muito interessante isto, porque éh, eu acho que quando agente estende a mão para alguém, não é? Agente não pensa no retorno, mas Deus, eu acredito muito em Deus, tá certo? Eu acho que 
ele que vê todas as coisas, que vê mais lá no futuro, e ele estende as mãos para agente, muitas vezes de uma forma indireta, então, quando este senhor encontrou o filho, entendeu? Ele já estava pronto a me ajudar a comprar a casa que eu precisava, ele era o dono, mas ele fez a condição para que eu talvez pudesse fazer, para que eu ficasse com a casa. .. Só assim eu teria a casa, é um detalhe que eu acho muito interessante, muito interessante.

Eu acho uma grande lição, antes de mais nada, fazer o bem e sem olhar a quem, meu pai não pode imaginar que aquele homem iria estender a mão para mim um dia, né? Afinal de contas, nada, nada, passaram-se mais de vinte anos entre a data que ele precisou da água e a data em que o procurei para comprar a casa.. Não podíamos fazer idéia, é muito distante... é uma situação muito engraçada.

No início deste relato, Raul afirma "eu não decidi" respondendo a pergunta de como ele havia decidido ir morar naquele lugar e é interessante observar que ele se coloca na posição de quem recebeu um legado de seu pai. Do ponto de vista da constituição de sua identidade como herdeiro da palavra do pai, esta casa o autentica como legítimo herdeiro e sucessor do pai. Raul explica que a premência de arranjar um local para morar era devido à mãe ter vendido a casa do pai e eles terem que ir para outro lugar, e ele encontra, ou melhor, reencontra este legado.

ii) A Decisão De Voltar Para Morar No Mesmo Lugar Depois Do Desastre

RAUL:

Então, quer dizer, este dinheiro eu usei para refazer uma parte da reconstrução da casa, para que nós pudéssemos voltar, foi feito com o pequeno valor de indenização que o seguro pagou. ... Já no dia dezoito, quando o pessoal da reportagem começou a me procurar, eu já havia começado a conversar com o pessoal aí, disse que nós precisávamos nos organizar para podermos resistir a isso tudo de uma forma organizada, que nós estávamos perdidos ... começou a nascer um instinto de tentar levantar o moral dessas pessoas, que eu sentia que era muito mais importante que nós tivéssemos o moral alto, do que tentar recuperar o que não tinha mais recuperação. Que aquilo não era tão importante de fato, já que a única perda 
de fato foi a que a Neusa sofreu. A perda real foi a da Neusa que não dá para repor a vida. Em função disso, acabei me tornando o líder natural.

De forma nenhuma (achou arriscado). Na realidade é, veja bem, depois de implantados esses tubos em 95, nós nunca mais tivemos nenhum tipo de problema aqui, entendeu? Se não fosse o rompimento dos açudes, mesmo agora, nós não teríamos tido nenhum problema, porque inclusive o estudo, ah da Universidade Federal de São Carlos, demonstra isso num laudo, que só as águas das chuvas não teriam colocado água dentro das casas, entendeu? Isso está patenteado num documento da Universidade Federal de São Carlos. O que demonstra que o que colocou água dentro das casas foi a obstrução dos tubos, causada pelos móveis arrastados da fábrica ... do depósito de móveis que tá logo abaixo da última barragem. Então quer dizer, há um fio de água que corre ali, sem esvaziar o excesso de água dos açudes, em situações normais isso não encheria de água, se encheu de água, foi porque o pessoal aliviava os açudes, isso anterior a 96, se encheu de água é posterior,... foi porque os açudes romperam. Então essa é a posição que eu sustento, não tenho, não tenho medo de continuar morando aqui. Tenho medo sim, tenho medo da impermeabilização que vai ocorrer mais acima, quando da implantação da urbanização. Tá certo? Por que o que vai acontecer? Que a água vai crescer substancialmente, agora eu moro aqui há vinte anos, tá certo? E posso te garantir que só pela água das chuvas, o córrego deveria ser menor. Existem alguns pontos que merece ser alargado, aprofundado, enfim, onde o Município tem que trabalhar para garantir que seja feito uma calha decente. Mas essa é uma outra questão. Essa é uma questão de éh... exigir o que é de direito, tá certo? Com relação ao volume de água, que eu realmente acredito que...

\section{MARIANA}

Eu não queria voltar! (risos)... a princípio eu não queria voltar, também dos comentários que a minha amiga fazia, começou a influenciar muito, então eu não queria voltar não, não tinha pretensão nenhuma de voltar aqui, não queria ficar aqui de jeito nenhum, vinha só de dia, e mesmo com sol ficava com medo, mas depois passou. (risos) . 
Figura 15 - Vista do entulho no córrego São Quirino no dia seguinte

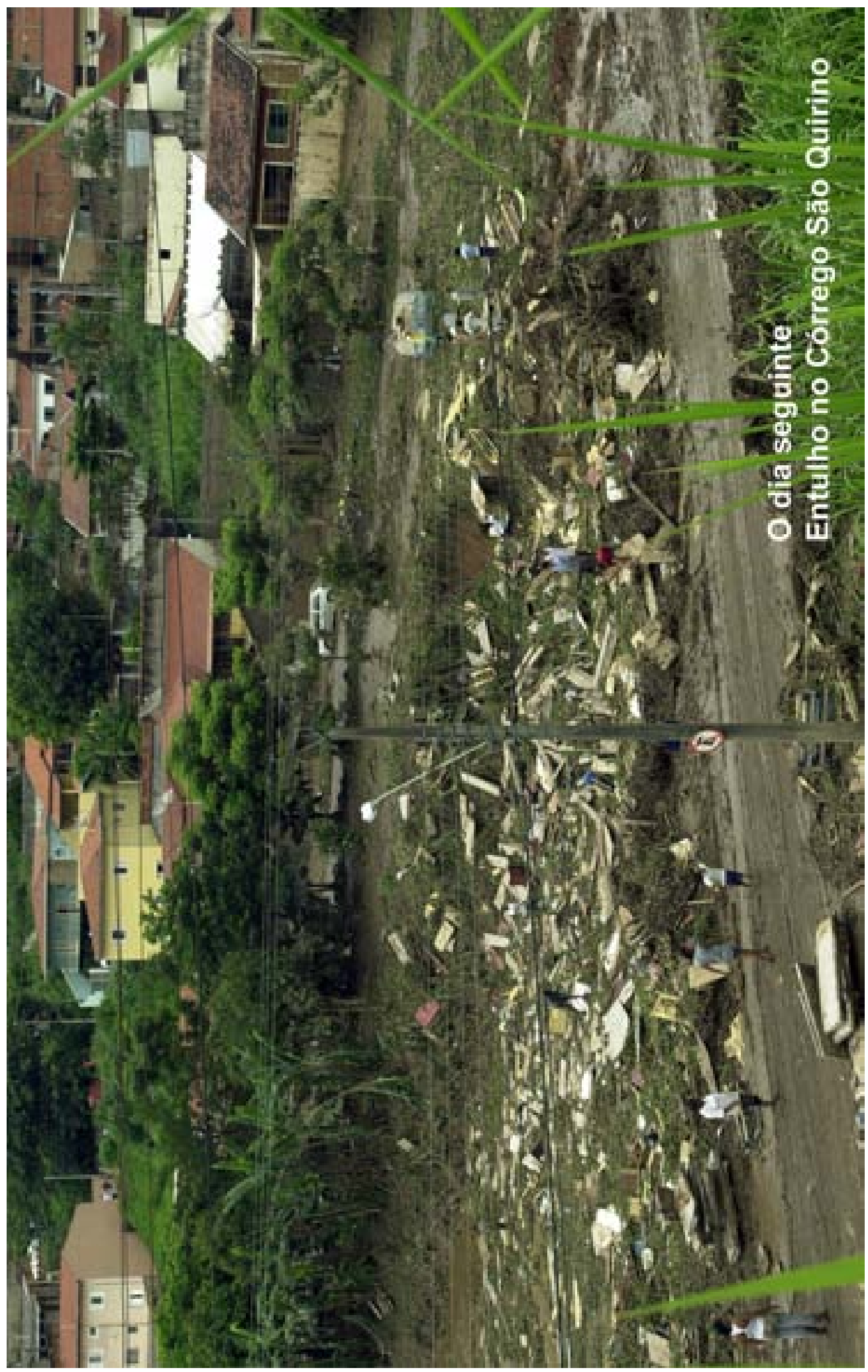


Para mim não foi muito problema, porque eu não estava aqui no momento, mas para ela (amiga Eliane) foi um grande problema, ela não queria voltar, ela demorou muito tempo para voltar, tivemos que conversar muito com ela, eu conversei muito com ela para ela voltar, pedi muito para ela voltar que a mãe dela precisava dela, mas ela não queria voltar. Ela não quer morar aqui, ela não gosta de morar aqui. Quando, há alguns dias atrás choveu, e a mãe dela ligou desesperada, pedindo para eu ir lá, para ver se ela tava lá, se ela tava bem. .... Quando chove ela vem para cá, para nossa casa que ela se sente mais segura, ela se sente com alguém perto, ela tem medo! Ela não consegue ficar sozinha quando chove. Porque no dia ela estava em casa, veio a água com tudo, não deu tempo de nada, ela tentou salvar os filhotes de gatinho que ela tinha e ,... mas foi um trauma muito grande para ela. Ela é muito sensível para estas coisas, e foi um trauma muito forte para ela. É uma coisa bem forte, neste sentido.

Também! Também! Bastante de mim. ... Eu não tenho medo de quando chove... Não, porque eu sei que não vai acontecer de novo, antes eu tinha, mas agora não, agora eu não tenho mais medo, não tenho mais receio de que vá acontecer de novo, antes eu ficava com medo, falava para eles que eu não queria mais ficar aqui, ficava perguntando: - Tem certeza que não encheu de novo? Tem certeza que não tá mais com água? Ficava perguntando toda vez, ficava perguntando se tinha água.

\section{CLAUDIANA :}

Para mim aquilo lá era tudo lixo, eu não queria mais nada daquilo, entendeu? Eu sofri por causa disso, mas por voltar aqui, não, em momento nenhum, e não foi a casa de uma vó ou a casa de outra avó, pelo contrário, $\underline{o}$ que eu mais queria era voltar pra casa, eu já tava saturada de ficar num lugar que não era meu, saturada de ficar fora do meu espaço. Por mais espaço que eu tenha de não ser o meu espaço

Que eu não concordo com o que a Mariana falou, que ela tava confortável lá a ponto de não querer voltar. Ela não queria voltar por causa de tudo o que aconteceu, porque ela chegou aqui e viu a situação, por causa do abalo da 
(amiga) ... e ela ficou muito abalada e isso mexeu com a Mariana, entendeu? Eu acho que a Mariana ficou muito mais abalada por causa disso, do que não querer voltar por causa do conforto, entendeu? Tanto que chegou a um ponto da gente pegar a (amiga) e levar para casa da avó junto, a gente levou ela para casa da nossa avó, ela ficou com a gente lá, durante umas duas semanas depois ela foi para casa da outra tia dela lá, né?

Eu não tive problema de voltar para cá em momento nenhum.... Tanto que eu fui a primeira dos filhos que veio aqui ... No dia seguinte eu vi, entendeu? Enfiei o pé aí no barro e levei uma picada de um bicho aqui na perna que até hoje não sei, fiquei com a canela roxa, deste tamanho assim, até hoje eu não sei que bicho foi aquele... E eu tava muito nervosa ... É, então, e eu fui picada por um pernilongo eu nem sei que pernilongo, ou não. Eu depois até cheguei a ir na farmácia, e o farmacêutico falou que deu uma reação alérgica, e que formou um hematoma, ficou roxo, roxo enorme e eu não tava nem aí que eu vim e queria ver, queria mexer, queria entrar.

\section{SOLANGE:}

Com certeza! Não! Não cogitamos em ir embora daqui ... Porque ... é uma questão de princípios, eu acredito assim. Eu ia pra onde? Primeiro, eu ia vender pra quem? Que consciência eu ia fazer isso? Então, não cogitamos a idéia de sair daqui, a gente achou que era uma questão de princípios ficar aqui e resolver este assunto. A gente queria erguer a nossa vida, com o que a gente tinha, a partir de um princípio para se chegar a um objetivo, acabar com esse negócio de uma vez por todas. Se a gente conseguisse, aí a gente cogitou, com o tempo, que se fosse resolvido, e a gente quisesse sair daqui, a gente teria o coração tranqüilo de vender isso aqui para alguém. Mas enquanto isso, se nós tivéssemos que sair daqui, nós íamos para onde?

Com relação aos argumentos apresentados para voltar a morar na mesma casa, há uma preponderância de construções de ordem emocional, e que não se ancoram na experiência traumática da enchente. É quase como se esta fosse delegada para algum outro plano de onde não interferisse mais na decisão que aparentemente já estava tomada. Percebe-se o enorme investimento de recursos afetivos e 
financeiros na reconstrução do local de moradia, e de onde vem esta sobredeterminação? Raul recorre a racionalizações apoiadas em pareceres técnicos que, porém, referem-se a outras condições, Solange recorre a ideologias, Claudiana à sua coragem e características pessoais e Mariana, talvez seja a única que reconhece que é por dependência afetiva na família e falta de condições afetivas para decidir algo que a o colocaria em oposição a família.

\section{Relíquias:}

RAUL: mostrando um estojo de couro destroçado com estes objetos inúteis considerando o uso para o qual se destina, fotografar profissionalmente.

Dentro de um armário no meu quarto, no dia, eu cheguei a pegar essa maleta na mão, ela tem tudo o que tem, é um conjunto da Nikon completo, e junto com o conjunto da Nikon completo, tinha também a minha câmara digital, que na época custava o dobro do que ela está sendo vendida hoje, ... que eu usava para trabalhar. ... Tudo perdido, sem recuperação.... essa lente que está aqui nessa máquina, só essa lente... essa lente que eu tenho na minha mão, custa tanto quanto essa daqui custava naquela ocasião, ou seja, essa lente aqui custa mais de dois mil reais, só essa lente, ou seja o corpo de máquina, eu sei tudo isso, deu muito trabalho para encontrar onde ainda houvesse uma máquina com estas características, que é uma máquina toda manual, extremamente profissional, entendeu? E é difícil, fica uma certa sensação... eu fico pensando, será que algum dia eu vou ter novamente?

Mostra no quintal onde está guardado um tijolo de barro.

Um cheiro horroroso fermentando, o barro que secou ... Eu tenho um tijolo de lama seca que parou dentro de um bloco de cimento destes de dois furos, que eu tinha no quintal, e a lama que tinha depositado dentro, eu não mexi com o bloco, ela compactou e secou. Com 6 dedos de altura de barro sólido, você imagina que antes de ter barro sólido, tinha dois palmos de altura, até perder toda água e compactar e secar, isso tá guardado no meu quintal, entendeu?

SOLANGE: Mostra com bastante entusiasmo o local na sala onde penduraram um pequeno quadro com uma paisagem campestre pintada. 
Tem um quadrinho. Tinha escova de dentes que veio de alguma casa e nós não sabemos de quem era, que desceu de alguma casa... Eu guardei um, como recordação, tinham coisas mais inusitadas, olha eu não tenho a menor idéia de quem pertenceu isso um dia. Tava dentro da minha casa! Esse é só um exemplo!

\section{CLAUDIANA E MARIANA:}

"Eu vou pegar o esmalte” As meninas vão buscar vidros de esmalte, entre risadas e os destampam rindo, para mostrar como ainda tem barro entranhado na rosca da tampa. Mostram também uma pequena caixa com vários pequenos objetos, achados no rescaldo que não têm a menor idéia de a quem pertenceram. Todos estes relatos são feitos em meio a risos e entusiasmo. 


\subsubsection{FAMÍLIA 3:}

Entrevista com o casal nomeados Mário e Lúcia. Todo o relato de Mário é bastante desesperançado, tenso e reservado e o de Lúcia é com uma agressividade contida que sugere uma raiva subjacente.

\section{A. Descrição dos fatos :}

LÚCIA: Estava dentro de casa no momento da enchente e saiu nadando.

De repente, quando eu olhei, pela porta, aqui em baixo da porta de entrada, eu vi que já entrava uma água lodosa, escura, suja. Mas entrou com muita força, que rompeu a porta, e já entrou na sala e já levantou tudo. E quando eu percebi que a água estava invadindo toda a casa, eu corri para o quarto, onde eu tenho um telefone, e liguei pro meu filho. Pedi a ele que chamasse o bombeiro, porque eu não tinha noção do que tava acontecendo, sabia só que tava entrando água, mas não sabia de onde, não sabia o que era, não sabia nada. Aí quando eu tava falando no telefone, a água já entrou nos quartos. Quando entrou nos quartos, que eu olhei, o computador já veio em sentido da porta, eu tava em cima da cama. Quando o computador veio pra cima da porta do quarto, ele comprimiu e foi prensando a porta pra fechar. E eu tinha muito nojo, porque era uma água horrorosa, fedida, horrível, aí pensei: - Bom, não tenho escolha, vou ter que pisar nessa água. Minha expectativa era que a água parasse, nunca podia imaginar que fosse acontecer o que aconteceu. Aí foi quando eu saltei da cama e agarrei a porta, que foi o tempo que tive pra sair do quarto. (...)Aí eu vim em sentido pra sala aqui, mas quando eu cheguei aqui, isso aqui já nadava tudo, tava tudo em cima no teto, eram outros móveis, né? Os móveis tavam todos no teto, o meu carro..,(...) Ele subiu cinco metros, (...) eu agarrei no batente da sala de jantar. Nessa porta entre a cozinha e a sala de jantar, foi ali que eu agarrei, porque a água subiu com uma rapidez tremenda. (...) Aí pela porta rompida, eu vi que eu só enxergava meio pneu do Tempra, quer dizer que a altura que ele tava já era muito grande, quer dizer que já estava tudo inundado. Quando eu olhei pra cozinha, a geladeira já estava no teto, todos os móveis tavam já no teto.(...) Mesmo assim, eu continuei na expectativa que fosse parar, porque o volume de água era impressionante, 
Foto 16 - Vista da residência da família 3 com as marcas da enchente

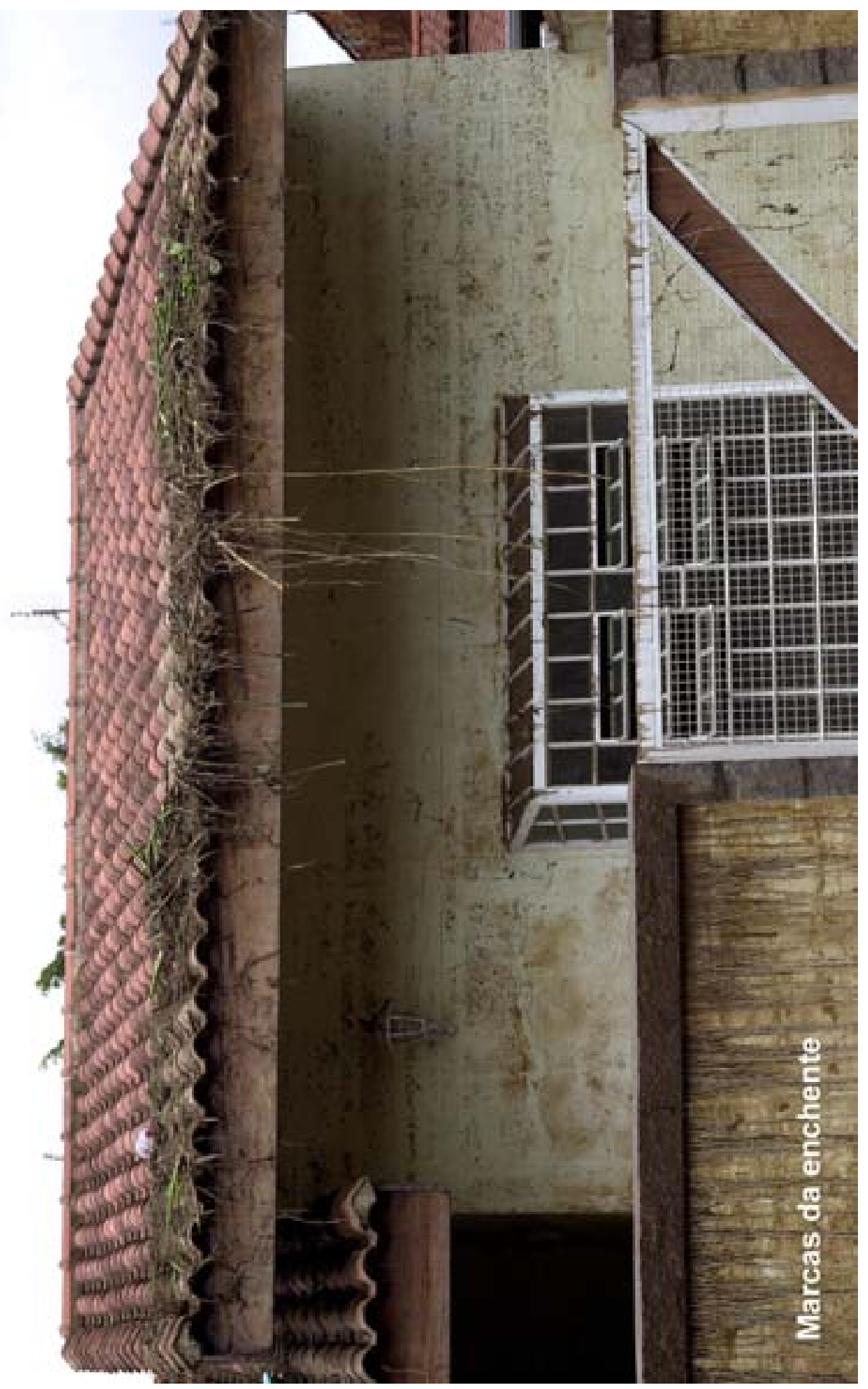


mas ela não parou! (...) Quando eu percebi que eu não tinha escolha, que a água chegou aqui no queixo, que eu não tinha mais para onde ir, que minha cabeça já estava encostada no teto, falei: - Bom, agora eu vou arriscar, porque ou eu morro afogada ou eu morro eletrocutada (...)Então eu mergulhei, fechei os olhos, porque tinha muito nojo da água, da textura dela, eu mergulhei, e tentei mentalmente sair pela área de ventilação (...)Aí passei a mão e vi que metade da porta também tinha rompido, metade fechada e metade abriu, e pelo tato, eu fui me sintonizando aonde eu tava, passei pro lado de fora, tudo mentalmente! Quando eu achei que eu tava já na área, aí eu me impulsionei meu corpo com o máximo de força que foi possível e subi, fui sair lá em cima no telhado. Aí, foi que eu tive noção, quando eu saí no telhado, que eu agarrei na calha, e consegui chegar lá em cima na cumeeira. (...)Só tinha um meio metro de cumeeira para fora, o resto tava tudo imerso na água. Aí que eu tive a noção, a extensão da tragédia, do desastre, foi assim uma coisa horrível! Essa rua aqui, tudo era um mar, parecia..., era uma pororoca, para ser assim mais, era uma pororoca, coisa assim impressionante! Ali, no telhado, eu fiquei um pouco, e a chuva continuava, não tão intensa, mas continuava. Aí eu percebi que veio um moço, que também vinha por outros telhados, e falou pra mim: -Você quer que eu te ajude a sair daí? Eu falei: - Quero! E logo uns minutos depois ele já veio com aquela escadinha, e naquela escadinha ele pôs entre um telhado e outro, e eu fui caminhando pela escada, aí fui passando para um outro telhado, para um outro, mais um outro, foram uns cinco telhados, até conseguir chegar na rua de cima, aí então meu marido já tava lá.(...) Eram cinco e dez quando a água entrou, porque meu marido tinha um relógio de família, daqueles relógios carrilhão antigos, o relógio parou em cinco e dez (...)Eu olhei, era esse reloginho aqui, eu falei: - São vinte para as seis! Então foi meia hora aqui dentro, até mais, porque cinco e dez foi que inundou a altura do relógio, quer dizer que começou antes, deve ter começado umas cinco horas. Então das cinco às vinte para as seis eu fiquei aqui dentro. Só saí mesmo porque eu tive muita proteção, se não eu não sairia de jeito nenhum.(...) Mas foi terrível! Sendo que eu tinha certeza que eu morria ali. Só que na hora eu pensei, perdido por perdido eu vou arriscar, foi quando eu 
mergulhei. Eu não queria mergulhar naquela água nojenta, nojenta, mas aí eu não tinha escolha, eu mergulhei.

MÁRIO: Não estava dentro de casa na hora da enchente

Tava voltando pra minha casa, eu tava voltando para a cidade, (....) tava ouvindo estas notícias do jornal, e quando eu saí do escritório (...) para ir para a cidade, a Delfino Cintra já estava alagada, e eu parei com ele ali esperando baixar a água, só que não abaixou, foi aumentando, aumentando. (...) Resolvi vir para casa, cinco horas da tarde vou para casa. Quando eu cheguei aqui estava chovendo ainda (...) sem preocupação nenhuma, nada, nada. Porque a CBN (estação de rádio) estava noticiando que a região da (rodovia) Dom Pedro, da cidade, da região do Shopping ... estavam chovendo demais, chuva simplesmente. Eu entrei no Parque Imperador, quando eu cheguei aqui eu olhei, que dei a volta e olhei tava tudo marrom aqui em baixo, eu parei o carro, quando fui olhar tudo tinha alagado. O desespero é muito grande né? (...) Cheguei justamente na hora que o pessoal tava correndo para salvar, aquele frenesi de correr com corda, com escada, e pessoas querendo ajudar, enfim, eu vim correndo, olhei para casa e não vi a Lúcia (...) cada um corria para um lado, não sabia o que fazer. Depois eu voltei pra cá, fui aqui atrás, tem um sobradinho de um amigo meu, eu olhei tava em cima da casa. Tá salva! Chorando, molhada e meu amigo tava lá. (...) $O$ meu desespero maior, quando eu cheguei e vi toda a área alagada, que eu não vi a Lúcia, eu pensei comigo, será que ela está fora de casa? Porque se ela está dentro de casa ela está morta. Porque o nível da água chegou ao limite já fazia uma hora. (...) E a outra preocupação era o seguinte. E se ruir a casa? E se desmoronar a casa? E se eclodir a casa? A Lúcia vai morrer afogada! Quer dizer, alguma coisa vai acontecer aqui. E se essa vazante aí estourar e a água levar tudo, sugar as pessoas que estão dentro da casa ou então alguma coisa. A preocupação era tirar logo ela daí, pra ficar livre. E se rompe esse barranco inteiro? Pelo volume de água, eu não sabia se está solapando por baixo ou não. Porque seis metros do nível da rua é muita coisa! Um pequeno furo na terra podia estourar tudo! Pelo volume de água, a pressão de massa de água é enorme, e se explode isso aí? Aonde vai parar o Parque Imperador? Tudo isso aí retido pela estrada de ferro? Logo depois a retiramos e fomos embora. 
B. Premissas:

i) Familiaridade com os antecedentes das enchentes, informações locais e parecer técnico

MÁRIO:

Ninguém é culpado, não tem quem vai responder isso para mim, nunca, jamais, mesmo que se pergunte a quem quer que fosse. Culpado porque vim morar aqui, ao invés de um lugar alto? Residi lá vinte e cinco anos. A princípio eu me questionei: - Puxa vida! Com tanta experiência da vida, eu ter morado em tantos lugares, por que eu não me questionei. Esse córrego vinha da onde, onde é a nascente? Ter percorrido isso aí em cima, hoje eu conheço como a palma da minha mão,... ter percorrido isso daí a pé, de carro, fotografando. (...) Por que eu não me deparei com isso antes? Ter ido ano passado, ou mais tempo atrás, na cabeceira pra saber o que está acontecendo desde a nascente até a junção aqui da calha de água. Mas eu não, (...) comecei a conservar aqui a frente, entrar em contato com a Regional, (...) tratar de melhorar essa frente (margem do córrego em frente da casa). Esquecer de ver ali em cima, sem outorga, nada mais nada menos que onze intervenções no córrego São Quirino. Por que que eu não fui ver isso antes? Culpa minha? Culpa dos outros? Eu fui o último a morar na rua, o Raul mora há vinte anos aqui, ele sabia das represas, mas nunca houve um problema, houve uma chuva muito grande, houve! Mas depois com um laudo técnico do DAEE, com outorga do DAEE, fiscalização, seria galgado não rompido, por que que das quatro foram só duas rompidas? A primeira e a quarta? A segunda e a terceira foram galgadas, o cara tá no planalto, a água passou por cima e esparramou, a última represa que foi rompida aqui na Fazenda José Leôncio tem cinco metros de altura do nível do córrego, cinco metros de altura. Agora vejam o volume cúbico de água que fornece isso aí! Por que que eu não vi isso aí? Por que que eu não conversei com outros vizinhos? Com outros moradores? Com a experiência que eu tinha de vida, por que que eu não conversei com o Raul...

Vou culpar quem? Eu acho que culpado existe, sem dúvida nenhuma, é um problema de ordem técnica, foi feito manancial até 1996, foi a região do 
DAEE, e mesmo os fazendeiros, os primeiros problemas surgiram e não foi feito nada de reparo. Todas elas têm irregularidade, uma que não têm outorga, em todas elas não outorgado o represamento, o barramento do córrego, essa é uma questão jurídica muito forte contra eles. E a Prefeitura negligenciou, também o DAEE que não fiscalizava depois de lavrar o laudo de irregularidade, por que que isso aí ..., eu não sabia que tinha esse laudo em 96.

Pode-se observar que a experiência traumática remeteu Mário a uma busca contínua e constante do culpado por ele estar passando por todo este sofrimento e perda. É como um martírio auto-infligido em que se pergunta sobre a possibilidade de ter sido mais cauteloso, o que é irrespondível no nível de consciência a que se pergunta. As (sobre) determinações para seu agir cuidadoso, porém inconseqüente, provavelmente estão em um nível de razão que poderíamos considerar inconsciente. Provavelmente, a racionalização presente no trecho sublinhado acima refere-se às razões subjetivas que determinam a decisão e não estão sobre o controle do sujeito. Mário busca ainda inocentar-se, ao remeter ao vizinho mais antigo que sabia da situação das barragens a responsabilidade por não tê-lo alertado, mas ante a fragilidade deste argumento volta-se novamente à pergunta que o tortura.

\section{LÚCIA:}

foi o rompimento de cinco açudes, que têm em fazendas aqui por perto, e no dia dezessete de fevereiro, como choveu muito, houve o rompimento dos açudes. E esse rompimento é que trouxe um volume de água espantosa, pra cá, pra essa rua. Não foi em função da chuva, mas sim o rompimento dos açudes, que também são clandestinos, né? Sem outorga. E nessa hora eu estava aqui dentro de casa, estava lendo, tava uma tarde chuvosa, chuva bem forte, mas tava tudo normal. Romperam porque, acho que, a força da água foi muito forte, lá em cima no primeiro, que é do Haras (...) famoso, ele teve o rompimento da barragem lá, no primeiro. Quando rompeu o primeiro, do Haras, ele com a força da água, o volume da água ele veio trazendo e levando outros. Então aquilo foi aumentando o volume de água, mas o primeiro a romper foi do Haras (Lúcia segue nomeando 
os haras, fazendas e seus proprietários) e mais uma outra aí, que eu não sei de quem é. Nessa (...) veio um técnico do DAEE, comentou comigo mesmo que tinha mais de um milhão de litros cúbicos de água. Só de um! Aí você idéia do que veio de água! (...) em 96, ou uma coisa assim, houve uma enchente aqui também, depois que nós ficamos sabendo disso, mas não foi assim uma enchente como essa. Aí foi o córrego que transbordou mesmo, porque ele não tinha a saída de água que ele tem hoje. Ele tinha uma boca só, então, teve uma enchente, e pelo que eu entendi, que as pessoas comentaram, subiu assim, né? De água. Tanto que dependendo da distância das casas, do recuo das casa, não chegou a entrar, ou então em quem entrou, entrou pouco. Pelo menos foi isso que eu ouvi! Mas não uma tragédia dessa proporção que foi, não! Então eu fiquei sabendo disso depois, eu não conhecia a história. (Os diques) não foram reconstruídos, estão todos vazios.

Sobre enchentes anteriores: Não, ele não encheu. Eu tava aqui dentro e eu controlava. Porque como a chuva era forte eu abria aqui, ou olhava por aqui, ( indicando o vitral da sala e a porta da frente que dá para o brigo do carro), eu abria o abrigo e olhava para ver como é que tava a chuva, ele (o córrego) não encheu (...) Mas ele, o riachinho aí, ficou no leito dele, normal. (enchente de 1996) É, depois que nós ficamos sabendo disso, mas não foi assim uma enchente como essa. Aífoi o córrego que transbordou mesmo, porque ele não tinha a saída de água que ele tem hoje. Ele tinha uma boca só, então, teve uma enchente, e pelo que eu entendi, que as pessoas comentaram, subiu assim, né? De água. Tanto que dependendo da distância das casas, do recuo das casa, não chegou a entrar, ou então em quem entrou, entrou pouco. Pelo menos foi isso que eu ouvi! Mas não uma tragédia dessa proporção que foi, não! Então eu fiquei sabendo disso depois, eu não conhecia a história.

Lúcia , por sua vez, parece que atribui toda a culpa do fato aos proprietários dos açudes e quase que se exime de qualquer responsabilidade por sua própria vida. Parece uma racionalização extremamente alienante, em que não se vê personagem de sua própria história e sim vítima das circunstâncias. È agida, não age. 
ii) Percepção da ameaça de perda:

MÁRIO:

(...) Mas fica marcado indelevelmente na vida da gente.(...) .(choro) $O$ desequilíbrio é muito grande, esse medo de perda de uma hora para outra, você amealhando a sua vida, vinte, trinta, quarenta anos, cinqüenta anos, para poder que ela realize alguma coisa, e quando você vê, você perdeu absolutamente tudo. É terrível! Nunca podia imaginar, na minha vida, que eu pudesse passar por uma fase tão difícil, mas tão difícil. Por mais que você tenha lido, por mais que você estude, por mais que você se espiritualize, você mostra que não tem força, você é completamente oco, é uma coisa, não tem ao que recorrer mais (...) mas uns meses depois, aquilo veio se agravando, se agravando, se agravando. Eu acordo à noite, eu não durmo mais, suo, transpiro demais. Me dá uma depressão muito grande, eu fico com muito ... fraco. (...) Mas de um tempo para cá, de uns meses para cá, eu acordo à noite, um pouco agitado, eu tô sentindo que eu me movimento muito na cama, na manhã, quando eu levanto, lençol do colchão ta completamente fora do lugar, tanto que eu viro para lá e viro para cá.(...) Então, de madrugada, quando eu acordo, eu lembro daquilo tudo que nós tínhamos. (...) Eu tinha documentos de empresa, contratos, documentos particulares, documentos de família que eu não podia ter perdido, certo? Sociedades que eu tive, alterações contratuais, testemunhas, documentos, o quê mais? (...). Eu não tenho como provar que você tinha, que você passou, que foi sucessor, que vendeu, quer dizer, uma série de documentos que não tenho, perdi. Não sei como resolver isso aí. Coisas sentimentais, herança de família, fotografias de família, lembranças de viagens. Eu gosto muito de motocicleta, e há mais de vinte, trinta anos, eu coleciono vídeos, fotografias, (...) Porcaria? Porcaria! Pode ser porcaria para meu vizinho, mas para mim não. (com raiva) Eu pra guardar tudo isso, pensei em desfrutar nos meus sessenta, setenta anos, minha biblioteca, minha discoteca, que eu vinha juntando há trinta, quarenta anos, coisas raríssimas! Pode não valer, nem pro meu filho, mas enquanto eu estiver vivo, vou desfrutar daquilo, né? Um autor que eu lembro, vou lá, passo a mão, leio. Não temos mais nada disso. Isso aí dá um vazio. 


\section{LÚCIA:}

Pra mim, o que mais gravou foi o nojo da água, o mau cheiro da água, que não era uma água assim limpa, entendeu? Você deve ter assistido Titanic, você vê como aquilo tudo boiava, ficou revolvido, atrapalhado, então foi exatamente aquilo, só que numa água suja, numa água lodosa, então isso que foi muito ruim, pra mim foi o que mais marcou. Mas depois passou, eu superei muito bem, não tive problemas maiores, mas foi um sentimento de nojo muito forte. ... Não é que eu achei, a hipótese não, eu tive certeza que eu morreria afogada, agora o que mais me preocupou na hora é que eu ia engolir aqueles matos, que estavam tudo dentro da casa, que tinha muito mato. Sabe aquilo que fica submerso em lagos? Você vê aquela coisa assim, tipo de alga, mas não alga, aquele mato lodoso, era aquilo que tinha aqui também, dentro de casa. E na hora que eu tava alí eu pensei: - Eu vou ter que engolir isso aí. Foi essa a impressão que eu tive, porque morte por afogamento, só poderia ser aquilo! (...)

Perdas: Indenização, indenização por perdas, de tudo que está dentro da casa, e pelas despesas que nós tivemos para refazer a casa e perdas por danos morais, né? Porque eu tava aqui dentro. E não só por mim, mas pelo meu marido também, que ele já tava doente na época, estava com uma cirurgia marcada de fêmur, ele ia pôr uma prótese no fêmur no dia 25 de fevereiro, já tava tudo programado. A enchente foi no dia dezessete, ele não tinha nem condições psicológicas, nem físicas para enfrentar uma cirurgia deste porte.(...) Aí a cirurgia passou, foi fevereiro, mas as dores foram aumentando, aumentando, ele estava extremamente prejudicado, aí quando foi primeiro de abril ele operou. Então, foi também um agravante da saúde dele. São danos morais tanto pra mim quanto pra ele, de maneiras diferentes nós dois sofremos.( ...) Então aí tivemos que fazer tudo de novo, a perda foi total, de tudo! Depois fogão, geladeira, televisões, perda de tudo! Eu acho que eu tinha umas quatro televisões, aqui foi tudo perda total, microondas, louças, faqueiro. Porque eu tinha muita coisa que era herança da minha mãe, perdi tudo, não ficou nada. Foi desaparecendo tudo. Tivemos que refazer mesmo os quadros, tive que mandar fazer os retoques, as aquarelas nós perdemos todas, nós tínhamos muitas aquarelas que era do Geraldo 
Figura 17 - Vista da rua com o rescaldo da enchente sendo retirado

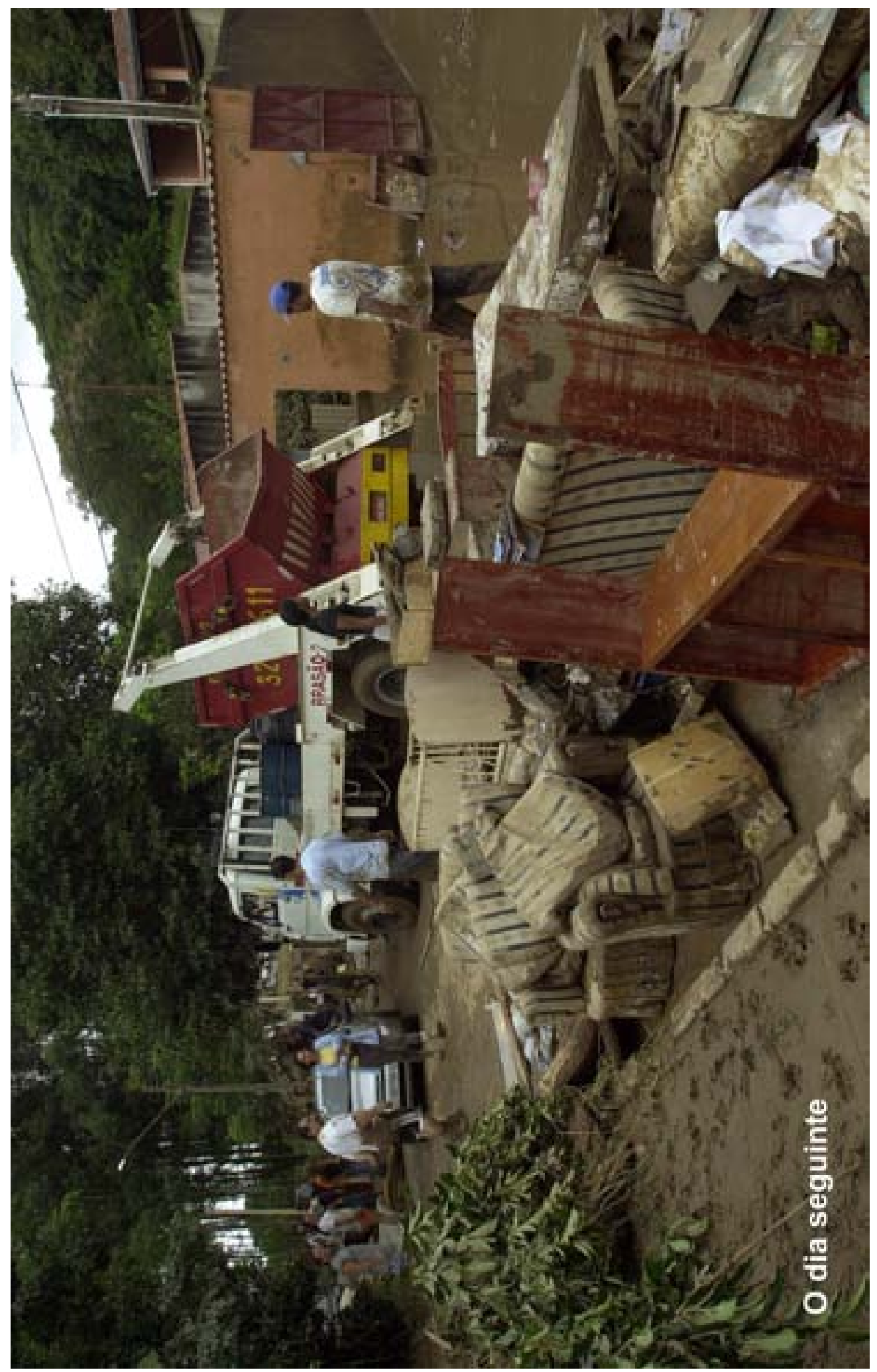


Jongersen, que era um artista plástico famoso aqui de Campinas. Ele era muito amigo do meu marido, então tínhamos muitas aquarelas. Houve perda total das aquarelas. Os óleos não, eu mandei fazer, refazer, tivemos que fazer todas as molduras novas. Não tem nada que não tenha sido refeito. (...) É começar do zero, como se você não existisse, porque não ficou um documento, não ficou uma certidão de nascimento, não ficou um diploma, não ficou as coisas dos meus filhos, não ficou os álbuns, perdeu-se todo o histórico de família, fotos, lembranças, certidão de casamento, de nascimento, escrituras, tudo que você possa imaginar, não ficou nada.(...) Certidão de nascimento eu nem tirei ainda, nem vou tirar. Fazer o quê? Não estou nem me preocupando com isso, mas houve uma perda total de tudo. Não tem jeito, é como se você tivesse..., um fênix, renascendo das cinzas. Não sobra nada, nada, mas o importante é que nós tamos aqui, né? Tanto eu como ele. Foi uma luta muito grande, agora não, já tá tudo tranqüilo, nós conseguimos pôr a casa em ordem.

iii) Percepção da mudança interior:

MÁRIO:

Não sei te explicar como, mas ocorreu (uma transformação). Bom! Essa perda material foi uma transformação muito grande porque eu as tinha todas, algum problema de ordem financeira, resolvia trabalhando, pagando e etc. (...) No passado eu tinha mais saúde que hoje, dificilmente eu ficava resfriado desse jeito, problemas de pulmão, na garganta, era muito passageiro. E eu vejo muito mais grave, eu penso muito mais minha saúde agora que há quatro, cinco anos atrás. Eu não pensava antes, eu saía de viagem, pra irmos até Poços de Caldas, íamos e voltávamos e passávamos em São Paulo...(...) Tô me sentindo mais frágil, sem dúvida nenhuma, fisicamente mais frágil. Eu tento compensar, em pensar positivamente, pensar em resolver o problema, quais são as falhas, em questionar, mas às vezes você não consegue...

\section{LÚCIA:}

Totalmente transformadora, você muda os valores completamente (...) O apego às coisas, ao querer cuidar demais ou da casa, ou do carro, ou de si 
próprio, enfim, porque eu sempre fui muito ordeira com as coisas, muito cuidadosa, (...) eu posso ser feliz com muito menos roupa que eu tinha, eu posso ser feliz com muito menos jóia do que eu tinha, que eu perdi tudo. Eu continuo a ser a mesma pessoa, morando no mesmo lugar, tanto faz ter um Tempra ou um Pallio, ou qualquer outro carro, desde que você tenha o básico de conforto, entendeu? Você perde estes valores que estão arraigados, que a maioria das pessoas tem. Estes valores muito convencionais que você vê com todas as pessoas, porque todas as pessoas agem da mesma maneira, $e$ têm os mesmos sentimentos, então isso tudo se transforma (...) Na hora que for embora vai largar tudo aqui, não vai levar nada, nem o corpo físico não leva.

\section{Argumentos:}

i) A escolha do local de moradia antes do desastre:

\section{MÁRIO:}

Bom...é, a casa tem dois, três anos, é uma casa zero, nós só mudamos para cá porque era uma casa zero, que a nossa casa, nós tínhamos que fazer uma reforma, para a gente gastar vinte, trinta mil reais na reforma de uma casa velha, não íamos recuperar jamais, achamos por bem tentar achar uma casa pra comprar. Nós vimos tantas casas! Podia ser mais em cima, mas tinha que ser essa. Por que que tinha que ser no Parque Imperador, na rua em frente ao córrego?

\section{LÚCIA:}

Tem dois anos que nós estamos aqui. (...) Que essa casa aqui, nós compramos novinha. Eu morava ali perto do Shopping Iguatemi, na Chácara da Barra, e meus filhos já estavam morando aqui nesse Condomínio Imperador. Então por isso que eu queria vir para cá, para ficar mais próximo dos filhos. Aí, quando apareceu essa casa aqui, eu gostei demais e meu marido também, então nós compramos essa casa. E viemos para cá. 
Em ambos são razões bastante subjetivas, proximidade com os filhos dela, embora Mário ainda esboce um raciocínio onde avalia as perdas e ganhos entre permanecer onde estava ou mudar-se para algo novo.

ii) A decisão de voltar para morar no mesmo lugar depois do desastre

\section{MÁRIO:}

Ah pensei (em não voltar)! Quando eu vi o estado em que ela estava eu pensei: - Não vou conseguir nunca colocá-la como era antes.(...) Agora eu não tenho mais medo de ficar aqui, porque eu sei que as represas que foram estouradas, foram rompidas, continuam secas, o nível de água muito baixo. .E agora os empreendimentos acima do Parque Imperador são obrigados a cuidar do leito do córrego, da calha do córrego São Quirino. Existe um projeto de urbanismo para cuidar de tudo isso aí, e vai ficar muito melhor que antes, que agora o Ministério Público está em cima (...) Agora, na época, eu pensei em mudar. Mas mudar para onde? Eu vou construir aonde? Se eu tiver que reconstruir vou construir lá mesmo que a casa é minha, é nossa. Fazer o quê? (...) Aceitar o que aconteceu como uma fatalidade da vida, uma coisa que nós tínhamos que passar por isso, como evitar passar por isso?

A volta: Eu tive realmente, um choque muito grande, mas não tanto como se estivesse chegado logo depois, uns dias depois, como ela veio, né? Ela viu a casa num estado terrível, estava irreconhecível!

\section{LÚCIA:}

Então foi essa a expectativa da hora, mas não tive uma má impressão depois, não ficou assim aquele trauma, nada. (...) Eu voltei para casa normal, mesmo na época da limpeza, porque eles já tinham tirado o grosso. (...) A mesma coisa. Gosto daqui do mesmo jeito. Não tenho medo, já tem chovido bastante depois disso. Já enfrentamos chuva forte, nesse período de um ano, pra mim tudo bem, normal. Não tenho medo, não fico preocupada, nada, nada. Eu gosto daqui, apesar dos pesares eu gosto daqui, gosto do lugar, acho aqui uma delícia.(...) É tudo, é bom. De manhã é uma delícia, isso aqui. Você abre a janela e vê essa tranqüilidade, cantar de passarinho, um sossego, não tem barulho de nada.(...) Mas eu gosto bastante, tanto eu como meu marido, 
tranqüilo, bons vizinhos, o pessoal excelente. Como tudo na vida tem uma dualidade, né? Com essa tragédia estreitou muito a amizade com os vizinhos que aí todos viviam uma mesma situação, então isso estreitou muito as amizades, porque todo mundo se achegou muito e meu marido e o Raul que estão tocando a parte judicial da rua.

\section{Preocupação quanto a volta para a casa:}

Nem passou pela minha cabeça não voltar. Eu acho que tudo é um ciclo. (...) Eu acho que se você tem que viver alguma coisa, você vai viver, seja lá onde você estiver, o acontecimento vai te alcançar, de uma maneira ou de outra (...) Bom, toda causa tem um efeito, não tem? Então se aqui nós cometemos causa e colhemos efeito, eu acho que nós tínhamos que viver isso. Não só nós, como todos que estão aqui, se não a pessoa teria vendido a casa pra outros, nós teríamos chegado um pouco tarde, teriam dito: - Não, já foi vendida. (...). Tanto é que meu marido não tava, eu estava. Então eu precisava viver e ele não. (meus filhos) nunca questionaram, acharam normal. Voltei e voltei muito feliz. Gosto daqui, gosto muito da casa. A casa é muito gostosa, hoje tá um dia meio morno, mas quando tá um dia claro, a casa é muito clara, muito gostosa, muito arejada.(...) Aqui ainda é o lugar que você pode pôr a cadeira na porta, no final da tarde, e conversar com os vizinhos, sabe? Ainda tem estas coisas que você não vê mais, não em Campinas, né? Campinas hoje é uma cidade extremamente perigosa, então você não vê mais estes hábitos interioranos assim. E no fim de tarde, fim de semana todo mundo põe a cadeira na porta e fica conversando e ninguém nem toca mais no assunto. Você vê como a natureza é perfeita, você esquece o bom e esquece o ruim.

A volta: Cada um faz do acontecimento o tamanho que quer.(...) . Mas o resto, voltou todo mundo e vive normalmente. Nunca vi aqui ninguém reclamar, ficar apavorado, pelo menos eu nunca vi isso, que tenha comentado comigo, eu nunca vi. Somos os mesmos, agora vamos ver, se eles pagarem uma indenização, vai ficar melhor pra gente, porque dá uma planejada, porque os gastos foram imensos. Não tinha condição, que pra você voltar pra casa se tem que ter uma estrutura, né? Senão, tinha ficado no apartamento do meu filho. 
iii) Sobre a possibilidade de prevenir-se contra a enchente:

MÁRIO:

Como prevenir, não tem. Por que que eu não fui lá em cima ver a represa? Eu ia achar bonita, e a quantidade de chuva do dia dezessete? Foi a maior em cento e três anos? Foi. É, mas se tivesse feito o reparo na represa quando foi feito o laudo em 96? Será que teria todo esse volume de água? Ou mais do que isso? A gente não sabe.

\section{LÚCIA:}

Totalmente imponderável, quem pensa que é a gente que resolve, essa é a maior ilusão do homem, você não resolve nada, porque cada dia que amanhece e você sai, você não sabe se você volta. Quem garante pra vocêe que você volta? Quantos saem e não voltam?

Interessante assinalar algumas diferenças e semelhanças entre os dois depoimentos. Ambos parecem achar impossível o exercício da previsão e da premeditação, idéias e ações indispensáveis ao exercício de uma "cultura de segurança”. Mário não confia em sua capacidade de observação, nem de interpretação do observável como parece indicar sua fala referindo-se a uma possível pré-observação dos açudes, "Eu ia achar bonita". Lúcia projeta para um outro plano as ações de avaliação e transformação da realidade e dessa forma se exime de culpa ou responsabilidade sobre o desenrolar dos acontecimentos.

\section{Relíquias:}

\section{MÁRIO:}

Não teve jeito, teve que jogar tudo fora, a biblioteca inteira. Eu venho colecionando livros, tô com sessenta e cinco anos, há vinte anos, tinha dedicatória de professoras minhas, isso não vale pra ninguém! Mas pra mim vale o quê está escrito lá. O professor que faz uma indicação de um livro a um aluno é muito significativo, certo? Essas coisas dá um vazio muito grande. Eu não tenho mais o quê perder. Isso, porque eu separei os meus discos, e os meus CDs, e estou lavando aos poucos, e tô ouvindo no meu 
carro, que eu tenho CDrom no meu carro. Por quê? É a satisfação que eu tenho, de ouvir música. Gosto de música, entendo de música, e gosto de bons livros. Isso eu não tenho! Estou tentando recuperar, estou recuperando, já estou com mais de mil CDs, não vou jogar fora! Se eu não ouvir em casa, vou ouvir no meu carro, mas aos poucos, tentando. A aparelhagem de som, eu desmontei todinha ela, e vou ver se eu consigo, de novo, fazer funcionar, pelo menos ouvir o quê eu gosto, né?

Vinte anos, há vinte anos toco um pouco, e sempre acompanhei os grandes pianistas, brasileiros e internacionais, tenho todos eles catalogados por instrumentos musicais, e pelo gênero. Na minha discoteca tinha todos eles separadinhos, um piano Jazz, um piano popular e etc. Sax, todos os instrumentos eu tinha, catalogados certinho, tenho metros ...

Parece que a perda identitária de Mário é algo muito avassalador, esta fragilidade de seu eu se manifesta em seu estado de saúde, com reflexos sobre seu corpo que está sempre em desequilíbrio, em seu sono agitado, e este limpar, recuperar e cuidar destes rescaldos do desastre podem representar um cuidar de si mesmo e tentativa de reparação ante a destrutividade dos acontecimentos. 


\subsubsection{FAMÍLIA 4 :}

Entrevista com o casal nomeados Luís e Maria. Ambos se mostraram tranqüilos.

\section{A. Descrição dos fatos :}

LUÍS: tem 64 anos e estava dentro da casa na hora da enchente. Seu depoimento começa sozinho e já no final do relato chaga sua esposa Maria.

... a água já tava entrando em casa, quando eu olhei a água já tava passando por trás de mim, as cachorrinhas, as duas, ..., eu tava na sala lá da frente, as cachorrinhas passaram aqui pra dentro com medo, né? E vieram pro quarto, e a água entrando. Enquanto eu fui lá dentro pegar, botei elas em baixo do braço e trouxe, quando eu voltei a porta lá da frente, aonde está a varanda, quando eu voltei na varanda a água já tinha lambido o meu óculos, isso aí, a água pra subir do chão até o teto, o telhado, foi entre dez e quinze minutos. E as cachorrinhas com medo! Eu botava elas pra nadar e elas vinham para cima de mim, e eu não sei nadar. Ainda bem que a porta ( da frente) tava aberta.... Eu subi, a água foi me levando. A água naturalmente leva a pessoa e eu fui me agarrando na beiras da porta, e fui subindo e passei, e quando cheguei lá em cima, saí pra fora, na varanda, e a água me levando, de vez em quando eu afundava. Aí nessa hora que foi mais desesperador, que eu não sabia nadar e não conseguia ficar em cima da água, e as cachorrinhas em cima de mim. Eu entrava pra baixo de água e subia. Duas ou três vezes eu pensava:- Eu vou morrer, eu não vou conseguir sair... Eu ficava sempre na esperança de a água parar de subir. E a água subia. Lá na varanda é assim também, não tem forro, é assim. Então eu fui subindo e consegui me agarrar na ripa. Quando eu me agarrei na ripa, aí eu levantei a telha, e botei as cachorrinhas para fora da telha. Quando eu me agarrei na ripa, eu tive a idéia de levantar a telha, para elas ( as cachorrinhas) poderem ficar respirando... Não botei elas pra cima, ... que lá não dá espaço. Aí deixei. Como elas ficaram respirando, elas ficaram lá. Vim me agarrando pela ripa até dar a volta.... fui me agarrando aqui, por cima... Pra cima do telhado, e aí a água ficou uns dez, quinze minutos, depois a senhora vê as fotografias, saiu na Internet, eu tô lá em cima com as 
cachorrinhas. Tem um bombeiro também, que depois chegou. Quando eu cheguei lá em cima, cinco , dez minutos depois, o bombeiro já chegou. .... depois que eu saí, isso também é um detalhe importante, depois que eu sai, depois que eu cheguei no telhado, era uma dor nos braços, nas pernas pelo estresse pelo esforço de sair da água, uma dor nos braços e nas pernas que ..., aqui nessa hora doía muito os braços e as pernas, ai o bombeiro perguntou para mim se dava para eu vim pra cá, por aqui ia fica muito difícil de me tirar, ia ter que botar num barco, porque também tinha um barco também, e por aqui logo em seguida eu subia o mato aqui (mostrando na fotografia) e pronto tava lá em cima. Ai eu vi assim, sentado apoiando só nos braços, vim até aqui, ardendo meus braços e as pernas.... Dor nos braços, porque eu tava tentando (---) na superfície da água, então batia os braços e as pernas também, foi nesse momento a causa da dor, desse esforço mas eu já tinha, repetindo, duas ou três vezes eu tive essa impressão de que não ia dar... Isso, vamos dizer assim, umas coisas que eu sempre lembro, que eu deixei о согро, que еи vou dizer mesmo, vou morrer mesmo, mas ai alguma coisa, acho que é um instinto natural da pessoa, vamos dizer de reagir, né? Ta entendendo, pra reagir e procurar sair de dentro da água, mas duas ou três vezes ... nesse tempo, pensei, vou morrer não vou conseguir sair daqui, não .... Mas esse é um negocio rapaz, que eu não vejo, vamos dizer, eu não lembro de ter chorado, que quando eu cheguei lá em cima, beleza, cheguei lá em cima, tranqüilo. Morrer afogado eu não morro mais, porque logo em seguida o bombeiro veio com o barco, por ali, e perguntou como é que tava, e tranqüilo e ainda falou para mim, vou lá no fundo no final da rua que tem um pessoal para tirar e depois eu volto para te tirar Então beleza, tranqüilo, e os cara dos vizinhos aqui de cima, é, tava dizendo por exemplo, esse vizinho aqui do lado, falou: - Luís fica tranqüilo ai, que a água parou de subir, não tá subindo mais não. Eu aqui tava tranqüilo, eu não lembro, eu não lembro de ter chorado, eu lembro assim que eu tava com muito frio quando eu sai daqui ... Tomei banho, lá na casa do vizinho aqui de cima e me botaram na cama com um cobertor, e botou um cobertor e não resolveu, botou outro cobertor e ai sim ficou bom. Mas eu não lembro, não com certeza aqui em cima eu não tava desesperado, eu não lembro de ter chorado aqui, 
Figura 18 - Salvamento de Sr. Luís no telhado de sua casa

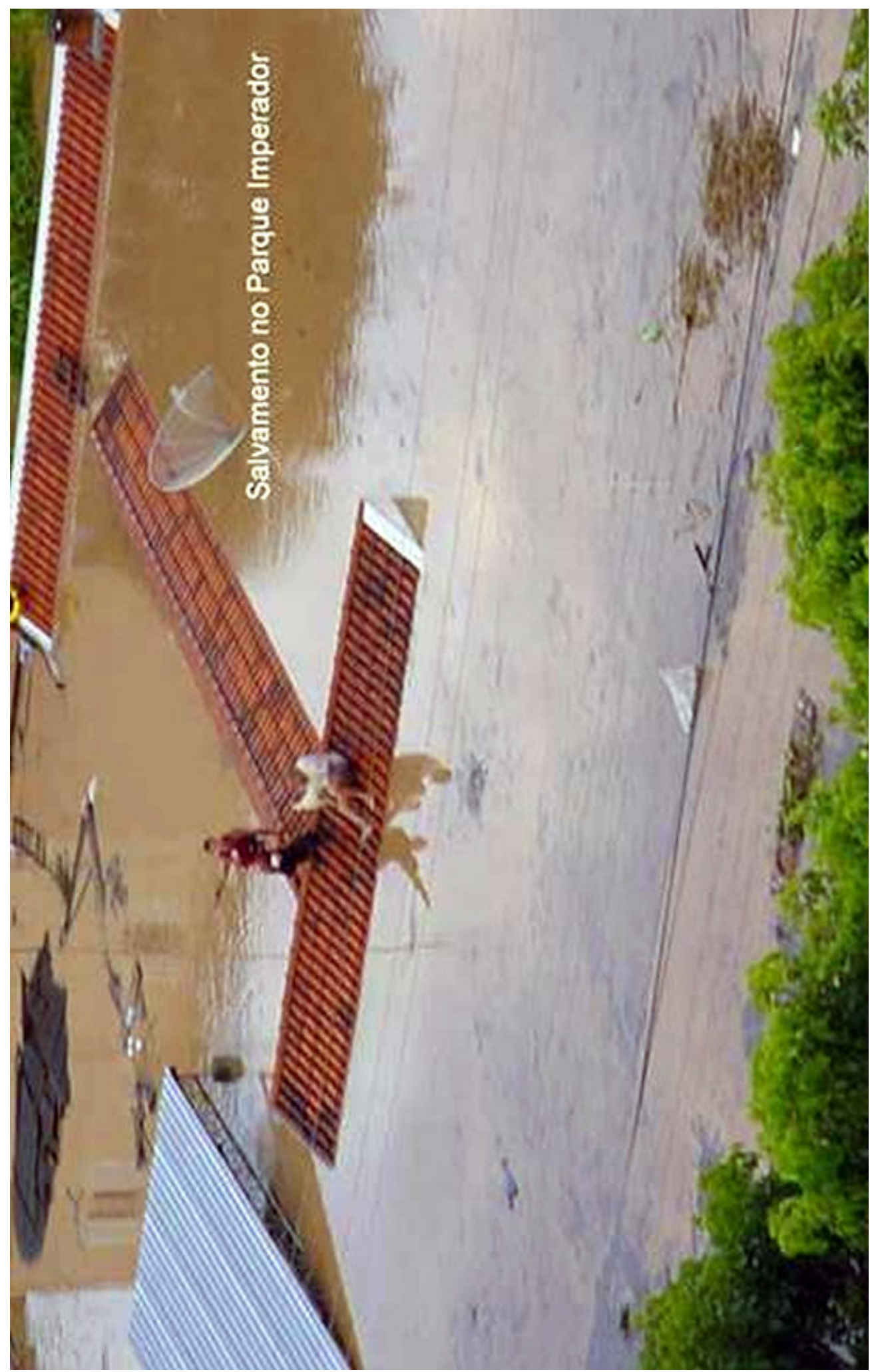


por que quando cheguei ali, disse: To salvo.... Claro, porque logo em seguida veio o bombeiro, esse bombeiro aqui (mostrando na fotografia) logo em seguida veio por aqui e avisou que ele ia até o fim da rua, depois ele fez a volta veio por aqui e disse: Vamos lá, da para caminhar até aqui? Mas ele não falou caminhar, ele falou, da pro senhor vir até aqui? Mas o senhor tem que vir se arrastando, claro porque se eu vou de pé, eu escorrego e ai ia ser danado, né ia ser pior...

MARIA (esposa, não estava em casa na hora da enchente, quando chegou o marido ainda estava no telhado esperando para ser resgatado.)

.... Um (filho) tava em São Paulo, foi levar jogador que ia embora, uns coreanos que estavam aqui e a menina trabalhando comigo, só que ela fica até mais tarde e ela não conseguiu sair de lá e chegar aqui. Eu, eu saí cinco horas, cinco e quinze do meu trabalho e só cheguei aqui, vinte para as sete, não passava ônibus pra cá, não conseguiu chega. A hora que eu cheguei, a água tava, já parada, ela não tava descendo, mais não tava subindo mais.... Eu na hora eu não sei, quando desci, o ônibus me deixou perto da padaria, eu não vi minha rua, não vi casa, só nada, só vi água .... ainda tava de dia, logo depois começou a escurecer, mas eu fiquei, levei o maior susto, porque eu não sabia o que tinha acontecido, eu perguntei por ele, uma amiga disse que já tinham achado, mas não me disse se estava vivo ou morto.... Ai eu fui pra essa casa, que ele foi depois tomar banho, tinha calmante na minha bolsa, eu sempre tenho um negocinho leve e tomei dois de uma vez e comecei a me sentir mal, achei que ia enfartar. Mas depois chegou uma e disse que ele tava em cima do telhado, vamos lá ver, mas eu não quis ir ver. Eu não vou ver como ele ta não, porque ele tava, tinha chorado bastante, que a vizinha falou que falaram, né! Uma vizinha que falou. Ele com as duas cachorrinhas, sem enxergar, sem óculos porque tinha perdido os óculos dentro da casa, porque nós achamos no dia seguinte.

Mas o resgate, foi muito rápido aqui, assim que eles chegaram no telhado, quando eu cheguei tava a maior..., tudo arrumado, o bombeiro, ambulância, tinha muita gente na rua. O pessoal da rua de traz, eles pegaram todas as pessoas daqui e levaram pra casa deles, essa rua, deram banho, deram 
comida, muita assistência . ... A igreja, nossa igreja aqui, montou um verdadeiro barraco pra, pra atende todo mundo, com roupa, com comida. Todo dia tinha ..., café da manhã e lanche ... almoço e janta, dez dias seguidos, pra todo o nosso pessoal aqui.... eu fiquei na casa de uma amiga minha.... Fora do bairro... Quando ela soube que..., o Luís, depois que tiraram ele do coiso, ele tomou banho e ele começou a roxear, ele teve hipotermia, né? e arritmia cardíaca, então eu pedi ao resgate pra levar ele pro (hospital), e ele ficou lá até uma hora, acho que meia noite, mais ou menos. Depois, a gente voltou no dia seguinte pro cardiologista, ai no carnaval, é que ele teve, leptospirose e ficou internado quatro dias, no hospital.

(Ele não conseguiu sair pela escada) É porque ele tem prótese de quadril total, nos dois lados ... Ele já fez cinco cirurgias, ... então ele não tinha nem um ano que tinha sido operado. E não podia se arrastar.... Ele foi jogador de futebol, teve desgaste nos dois lados, ai teve uma cirurgia de um lado, depois do outro, daí quebrou prótese dentro do fêmur de uma depois quebrou prótese ... quando eu cheguei e vi que ele não conseguia levantar eu falei pro bombeiro: - Avisa que ele não pode andar, tem que tirar ele. Daí colocaram essa bóia, porque ele não vai conseguir.... Nossa, uma tranqüilidade, mas quando ele ficou deitado na casa dessa vizinha, tomou banho tudo e começou a se sentir mal, tudo coberto, já com roupa toda limpa que deram lá, né? Eu chamei os bombeiros, entraram muitos no quarto que ele tava, mas não era assim um não eram três quatro. Hipotermia.... arritmia, porque ele tem, uma, tem arritmia cardíaca mas assim, num coiso de estresse, numa situação de estresse o médico explicou então quando fica nervoso dá isso. Mas não assim, nervoso normalmente, uma coisa de estresse.

\section{B. Premissas:}

i) Familiaridade com os antecedentes das enchentes, informações locais e pareceres técnicos:

LUÍS :

Não era, quer dizer, a água não veio pelo córrego direitinho assim não, ela veio por cima, porque ela rebentou o açude e a água veio, pegou, pegou um 
galpão de uma fabrica de moveis ... porque e esses móveis são, esses móveis de... é... Modulados, né? Então eles pararam ali no bueiro, tem mais ou menos a minha altura, são três bueiros, mais ou menos da minha altura, um pouco mais baixo, um pouco menor. Esses móveis pararam ali no coiso, no bueiro. ... A água não passou, ai foi uma seqüência, arrebentou o açude, a água veio pegou os móveis, e os móveis entupiram o bueiro e a água não tinha como sair. ..., mas o impressionante é a rapidez que a água subiu. Nessa (praça), nisso que eles vão fazer nessa construção ai, lá no principio da rua, o córrego é muito estreito e... raso... então qualquer chuva, não. Uma boa quantidade de chuva, alaga porque demora a água vim de lá para cá, primeiro é sobe na rua a água pra depois vim para cá, mas com o tempo ela vai escoando pra cá e pronto, baixa. Isso ai eles também tem que, que resolver esse problema, porque esse ai é um problema, vamos dizer que, eles tem que abrir e ... nessa abertura vai quase atingi a outra, rua de cima.... Paralela com... O córrego ta entre essa rua aqui e a rua de cima, lá no principio, porque essa rua faz assim, é assim, porque lá no principio como é muito estreito... vai ter que...Alargar, pra alargar, alargar o córrego vai.... quase que atingir o nível da rua... Então eles tem que fazer, o órgão da, .....o gabião ou muro de concreto, alguma coisa assim pra poder chegar e abrir.... Isso ai também é uma coisa que, vamos dizer assim, que a prefeitura precisa fazer e o ministério público esta de olho nisso ai... Porque, vamos dizer, não vai fazer praça, fazer nada sem antes... Fazer essas duas coisas, essa, resolver o problema lá do principio da rua e resolver aqui, o a obra que o (loteamento) tem que fazer aqui, pra não ter mais esse problema de chover, tem o escoamento da água e lá não vai, a água não vai subir em cima da calçada. Que isso foi por conta dos açudes. Não tem chuva que possa botar, só chuva, que possa botar a água na altura em que ficou, levando em consideração toda essa área de escoamento, tem que chover muito pra água ir lá em cima,...

MARIA:

Tinha havido um .... ha uns dez anos atrás, mas não assim. Esse canal aí, só tinha uma boca, aí depois dessa enchente de dez anos atrás, eles colocaram 
mais três bocas, e nunca mais encheu. Só que essa enchente não foi do canal, não foi do córrego. Essa enchente foi do rompimento das represas, são três represas lá pra cima, nem sei quantas! Então ela romperam com a chuva, muita chuva e eram represas irregulares. Aí aconteceu isso, a água inclusive, né bem? Veio depois da chuva, pela calçada, ela não ...pelo córrego, ela veio como uma onda lá de baixo, igual..., igual no mar mesmo.

Depois, uns dois meses depois eu fui bem perto, o pessoal tava pescando, ela estava estourada do mesmo jeito, saindo uma água bem devagarinho. Agora só tem mato, eu acho que acaba, acabou a água, né? Essa é só uma porque são três.... Pouquinho, inclusive teve muita chuva forte e nem subiu a água, nada, não foi do córrego. Isso daí (a prefeitura) quiseram provar que foi do córrego, mas não foi.... Agora tem um laudo, né bem? Lá na prefeitura, não sei, pra construir o (grande loteamento), que sai lá do (...) pra cá eles tem que fazer a obra junto com a prefeitura. A prefeitura vai fazer uma parte, a praça, a e outra, desde que eu vim morar que essa praça ta pra sair, parece que tinha setenta e dois mil (reais) pra praca. ... Setenta e cinco mil pra praça, depois ficou sessenta e oito mil pra praça e hoje não tem dinheiro $\underline{\text { nenhum, isso ai tem que ser dito também, não sei pra onde você vai colocar }}$ isso ai, mas tem que ser dito.

É, toda a margem do outro lado do colégio, ali beirando também o colégio, ia ter até banheiros... Que isso é uma praça... preservada do Ibama, essa parte aqui, esta da frente aqui e do lado cá e do lado de lá. ...Domingo tinha muito sagüi aqui...E outra tem tucano, muito pássaro diferente vem aqui, isso aqui esse lugar aqui é muito gostoso, o pessoal aqui anda muito nessa rua, esse pessoal de cima, né? Do bairro vem andar muito aqui, é cheio de gente andando, você vê essa gente idosa andando que o medico mandou andar, vem tudo andar aqui porque é reta, a rua é plana, então é um lugar gostoso. Só que a Prefeitura, há cinco anos que eu estou aqui, essa praça já ia sair a dez e até hoje não tem dinheiro. Quer dizer, tinha porque já tava aprovado, porque tinha setenta e cinco mil pra praça, não saiu a praça, não saiu o dinheiro, deu essa confusão todinha 
É interessante assinalar como Maria se utiliza da informação. De maneira truncada e confusa que a impede sistematicamente de chegar a um pensamento conclusivo. Ora são três barragens, ora é uma só, ora a responsabilidade é da Prefeitura, ora é de alguma entidade anônima referida como "eles". Por fim, volta-se para a descrição das obras paisagísticas projetadas para as margens do riacho, em frente a sua casa como se representassem a solução para o problema e a frequiência com que refere-se a órgãos públicos (Ibama, Prefeitura) parece querer reafirmar para si mesma que com a presença deles sua segurança estaria garantida. Parece que Maria também não se vê como personagem de sua história que está sendo escrita por outros.

ii) Percepção da ameaça e da perda:

MARIA:

Quando eu cheguei aqui, já tinha acontecido, né? O meu foi o maior susto de ver minha casa ali assim, eu pra mim, aquela água ia baixar e minha casa ia ta boazinha, mas não tava. O mato dentro de casa, era o que mais tinha e tudo o que tinha de sujeira, tava aqui dentro, nós levamos uma semana pra limpa, mesmo assim porque não teve água. Nós ficamos sem água, o bairro, uma semana. Eles cortaram mesmo por isso, por causa desse negócio de leptospirose, pra ninguém usar a água eles cortaram a água. E que também estourou uma ..., o cano, ai sei lá, uma adutora, ai eles tiveram que corta mesmo. Mas ai depois quando a gente começou a limpar a casa, e nós ficamos, eu com ele, mais meus filhos espalharam meus cachorros na casa de amigos, ai eu falei: A não, de hoje em diante nós vamos limpar com os cachorros aqui e os filhos aqui .... Fiquei passada, daí é o seguinte, aqui a gente teve que ficar, porque teve saques, vinha um pessoal de não sei aonde, e saqueava mesmo, então se você não estivesse em casa eles entravam e o que estivesse perto eles levavam, então você não podia abandonar a casa... Tudo que tava dentro da casa estragou, não dava pra você lavar, cobertor não dava pra você usar aquilo, mesmo que você..., uma sem água, (---) roupa nós perdemos todas as roupas, eu fiquei com a roupa do corpo.... Os documentos todos, na lama, nós perdemos muitos documentos. O carro, que já tinha, já tava com problema o carro, que tinha sido roubado, já tinham 
Figura 19 - Vista da residência de Sr. Luís no dia seguinte

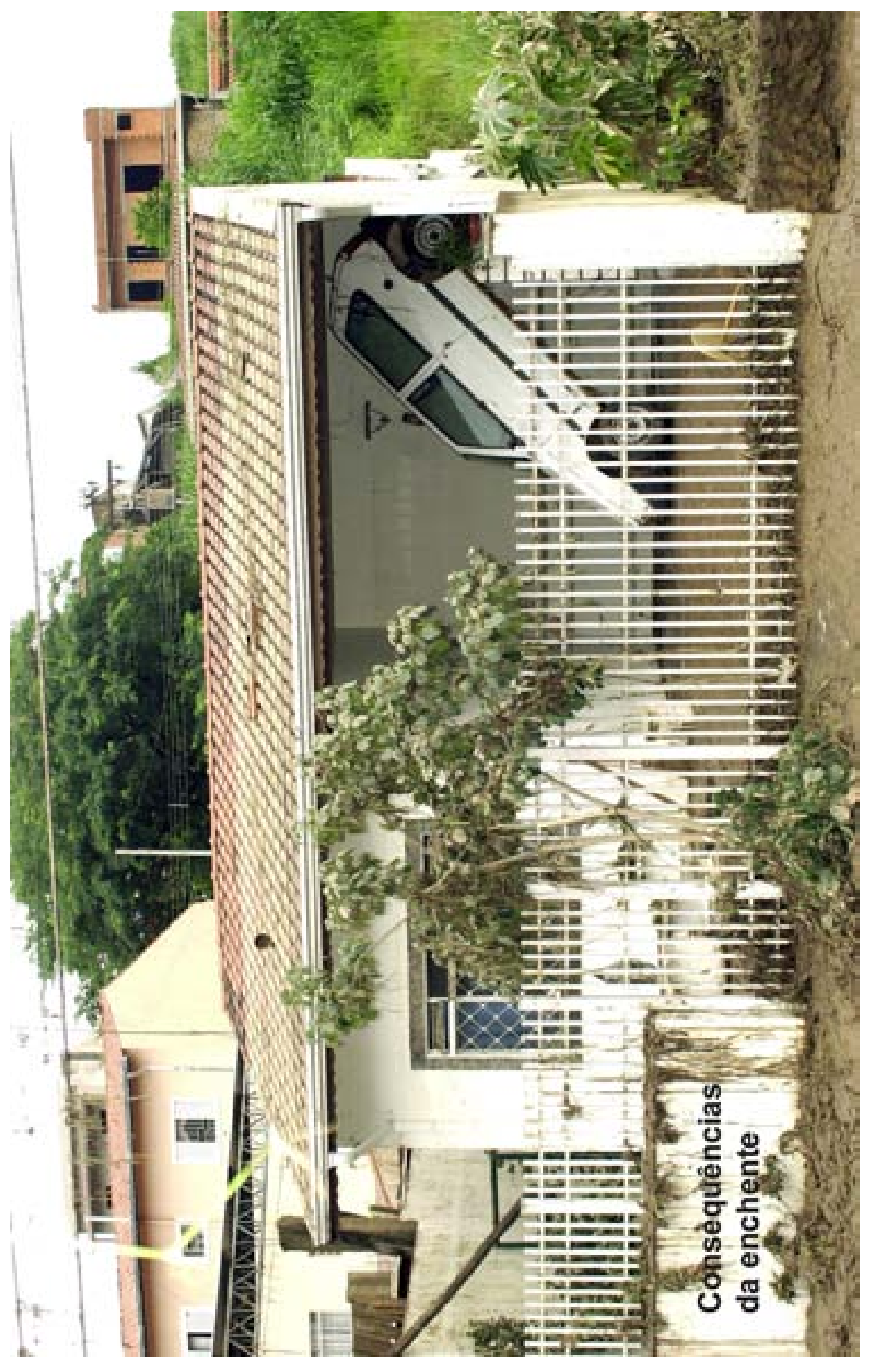


pego todos os bancos, então o carro ficou..., agora que nós mandamos consertar. Porque a gente viu que não é nada, porque em dois minutos você perde calcinha, soutien, sapato, você perde suas jóias, da maneira que for, com fogo, com água. Então, é você perde, perde roubando, alguém roubando, saqueando sua casa, matando gente dentro de casa, então a gente tem que viver o presente bem, em harmonia. Porque nós, não somos nada. Todo mundo diz isso, é uma frase boba, mas é verdade. Eu nunca pensei em passar por uma situação dessa, eu nunca pensei. Perde tudo dentro de casa, eu tive que reformar a casa inteira, eu tinha uma porta aqui, que estourou, a água levou a porta, desse jeito. A janela, tudo arrebentado, arrebentou tudo, tudo o que ta dentro da minha casa, nós tivemos que trocar, desde piso até porta e janela. As portas, ali do lado, foi embora. A sorte é que ele estava com a porta aberta porque a força da água, se ele não tivesse com a porta da frente aberta, a força da água, não ia deixa ele abrir, ele ia morrer afogado aqui, ... Se eu tivesse lá eu tinha morrido, eu não sei nadar.

Porque a prefeitura não fez nada pela gente .... Só mandou carro pipa pra lavar, nada. Uma cesta básica, para tirar pra gente foi um sacrifício Veio tudo vencido, coisa que eu joguei fora, fubá vencido, feijão vencido, arroz vencido, tudo vencido, mas vencido assim de três meses, que se a gente fosse para justiça, todo mundo juntasse e levasse para uma delegacia e fizesse um B.O., eles iam entrar pelo cano, e bem devido.... que a prefeitura não faz nada, a Prefeita veio aqui na minha casa duas vezes, a ultima vez viu, veio. Ela disse assim: - Agora a sua casa ta bonita. Eu falei: -Agora minha casa ta bonita, mas o que a gente passou, ta feio ou bonito, não é assim, não é? Não veio perguntar se a gente não tava precisando de nada não, não veio mesmo, veio só pra ..., sabe, encher lingüiça. Ela quase apanhou aqui.... Nossa, ela quase apanhou, pode colocar isso ai bem grande, ela quase apanhou na rua, só não apanhou porque as pessoas são educadas aqui, porque a revolta não deixou, porque iam linchar ela. Quando ela começou a andar aqui na rua, pra se mostrar.

A preocupação manifestada com o possível saque nos destroços, porque como Maria mesma falou tudo que estava na casa se estragou. Parece que esta passagem 
confirma a impossibilidade de um uso conclusivo da informação presente na experiência.

iii) Percepção da Mudança Interior:

LUIS:

... eu acho que, uma coisa eu sempre vou falar desse evento, desse acontecido ai, eu sempre vou falar, porque isso pra mim é uma vitória, por ter saído de dentro da água sem saber nadar e o esforço que eu fiz, tanto que me doía os braços e as pernas, então vamos dizer assim, eu tenho muito para continuar vivo, então isso pra mim ... eu sempre vou, não como uma tragédia, pra mim não, como uma vitória, é como pra mim também, como eu deixei de fumar, ate hoje, não, eu deixei de fumar, pra mim é uma vitória e isso ai eu ter conseguido sobreviver, é uma vitória, sobreviver e conseguir colocar nossa vida no rumo de novo, pra gente já ter desenvolvido, do que já aconteceu até agora, já andou muito.... Eu faço a minha historia sim, eu faço a minha história, eu tenho meus objetivos e tipo vou fazer isso vou fazer aquilo, vou pagar as multas, vou fazer licenciamento... ta muito bem encaminhada à coisa, dali daquele telhado até agora, já andei muito e andei não foi assim questão de sorte, nem coisa nenhuma, andamos, nós andamos com os objetivos, vamos isso, vamos fazer aquilo.... : É vitória nossa, dos quatro...

MARIA:

Eu acho que, eu vivo o meu presente e o meu futuro, eu sempre programo meu futuro sempre pro bom, ou melhor eu nunca acho que o que eu passei serviu pra atrapalhar minha vida, pra mim sempre tem uma coisa boa, eu sempre fico esperando as coisas melhorar e melhoram. Eu e ele temos este pensamento, a gente não fica amarrado em coisas ruins, ele às vezes diz, assim: De vez em quando dá uns flashes na minha cabeça... eu me afogando. A gente podia ter até outro nenê e botar o nome Vitória, né?

C. Argumentos:

i) A Escolha Do Local De Moradia antes da enchente:

LUIS: 
É porque quando eu cheguei aqui, fui transferido para cá, chegamos aqui em oitenta, depois que eu fiquei um ano, ai nós fomos transferido para Fortaleza, fiquei um ano lá e depois voltei para Campinas, me transferiram de novo para Campinas, ai daí para frente eu fiquei aqui em Campinas trabalhando aqui. Ai em oitenta e nove o banco me mandou embora, eu oitenta e nove, ai depois eu trabalhei de novo no Bandeirantes, no banco Bandeirantes, daí eu me aposentei em noventa e quatro eu dei entrada no meu, na minha aposentadoria, daí ficamos aqui, né? Porque aqui que, vamos dizer, a família toda tava aqui, (filha e filho) , eu, Maria, daí ela já tava trabalhando no (instituição), ai ficamos aqui, mas também por gostar daqui, né? Não só por força dessas ligações.

MARIA:

Eu casei no Rio e fomos pra Recife, ele foi transferido pra lá, ele era do Banco (...) gerente de Câmbio, aí de lá agente andou por Santa Catarina, Fortaleza, e aí a última capital foi São Paulo. E aí a cidade de Campinas. Estamos aqui ha mais de vinte e três anos. Eu morava lá na José Bonifácio, no Jardim Flamboyant. E eu sempre tive vontade de vir pra cá. Eu procurei uma casa, achei aqui. Já tinha uma pessoa conhecida que morava aqui, aí agente veio pra cá. Gostei da casa.... Vai fazer cinco anos agora em julho.

ii) A decisão de voltar para morar no mesmo lugar depois da enchente:

LUÍS:

A não, eu nunca pensei, ... sempre quis voltar pra cá, eu não pretendo sair daqui .... Eu gosto muito daqui.... Não, (não tem medo ) quando chove, eu não me preocupo, de maneira nenhuma me preocupo. ... A gente tem, vamos dizer, fatos que mostram que as coisas estão andando pra frente, então vamos dizer, não quero sair daqui, gosto muito daqui, essa enchente é um negócio que podia ter acontecido em qualquer situação onde a gente tivesse, algum tipo de prejuízo que a gente teve antes, podia ter acontecido em qualquer lugar, acho que a gente conseguiu botar a vida para frente, nós temos cada vez menos dificuldade, o carro daqui um mês já estamos de carro de novo. 
É interessante assinalar uma aparente contradição entre esta fala de Luís a e a outra em que se diz produtor de sua história. Tanto uma formulação como a outra parecem servir o propósito de deslocar o atenção da situação em jogo relacionada com a ameaça que este particular local de moradia oferece e a formulação de um raciocínio avaliativo sobre as possibilidades de ocorrência futura destes eventos.

MARIA :

Não engraçado, não. Eu quis voltar pra minha casa, inclusive até eu dei uma reportagem uma vez pra um jornal que veio aqui, e eu falei, e o Raul ficou até chateado comigo, falou no dia seguinte: - Você não podia ter dito no jornal que não queria o dinheiro, que não queria indenização. Porque eu falei pro jornal, não quero indenização, eu quero tranqüilidade, eu quero que aquelas represas lá, não encham mais ou que seja tudo legalizado que seja de uma maneira que não transborde mais aqui, porque eu quero minha casa, eu paguei por ela, não invadi terreno, eu paguei pela casa, eu quero é tranqüilidade. Se a justiça falar assim, olha não vai encher mais acabou represa, não preciso mais dinheiro. Eu não quero dinheiro, pra que o dinheiro? Eles vão me dar o dinheiro pra eu comprar outra?... Você sai daqui, e vai comprar no Cambuí, ai você leva um tiro de bala perdida. Aqui não tem bala perdida, aqui foi água, não é, não é, vamos dizer aconteceu isso, vamos em..., vamos ajeitar pra que não acontecer mais, não é? Não vai porque não acontecia mais porque abriram lá aquele buraco, então não tava acontecendo mais. Mas foi provado que foram as represas, ta provado. Agora que eles vão pagar, eles vão pagar, mas quem vai receber, eu não preciso saber, se são os meus netos, meus bisnetos. Agora eu e ele, agora hoje eu digo assim: Ah, hoje teve um dia que a gente tava até conversando, no dia que eu me aposentar, eu digo pra ele, nós vamos morar numa praia, morar numa praia pra gente poder andar de manhã, de noite, né? Na beira da praia, comer muito peixe, coisa que a gente não faz aqui, mais não por causa disso, não que isso? Essa casa, a gente veio pra essa casa porque a gente gostava dela e tem mais há cinco anos que eu planto um pé de uva, e enquanto essa uva não der, eu não saio daqui. Tem cinco anos que eu tento 
tirar um cacho de uva, veio à enchente e levou meu pé de uva, daí eu plantei outro, não deu, daí eu plantei outro, essa aí ta crescendo, vai longe. Enquanto não der um cachinho de uva eu não saio mesmo daqui, tem que dar um cacho de uva e é isso, eu não penso em sair por causa disso, não.... não é uma enchente que vai tirar a gente daqui, e é um mundo agradável, isso aqui é muito bom

Eu acho que o que tem que acontecer acontece, né? Num foge né? Você foge da morte? Não foge, não adianta o que tem que acontecer com você acontece... Ai eu saio daqui e vou pro Cambuí, ai acontece um negócio lá onde eu moro, um acidente, um negocio qualquer, entendeu? Você, não adianta você correr... E você tem que estar centrada, né? Bota a cabeça pra funcionar, não vou sair botando os pés pelas mãos, tenho uma casa financiada, ai vai vende a casa ir pra um aluguel fica apertada, pra que?.. .Entendeu eu não acho, que tem que ser assim, agora as coisas tão caminhando pra resolver isso aqui, agora a gente tem que esperar, não adianta sair. A gente já passou coisas ruins assim, com isso. A dois anos que a gente ta sem carro, a gente já passou algumas coisas que não é o fim do mundo, mas também não é agradável, né? A gente sempre saiu muito, sempre passeou muito, sábado e domingo com carro, volta à gente ta assim há dois anos que a gente ta assim sem carro, já estava antes sem carro agora as coisas estão se encaminhando, agora o carro já ta no conserto, a casa já foi reformada, né? Então as coisas tão..., eu tinha acabado de pagar minha cozinha, tive que fazer ela outra vez, a cozinha e os banheiros, porque os armários caíram, você colocava uma panela no armário e ela ficava verde, a panela e o armário

Observe-se o pedido de Maria, "eu quero é tranqüilidade", como uma garantia de proteção eterna. Este é de certa forma o que todos demandam, a total proteção, que em um primeiro momento é dirigido aos pais e depois com o transcorrer dos anos é dirigidos aos seus substitutos, maridos, patrões, governantes e a justiça. Ao colocar esta demanda mesmo que revestida de justificativas e queixas de ressarcimento, também desloca o foco da experiência em si e substitui a possibilidade de aprender com a experiência pela colocação de uma reclamação 
indignada que não é dirigida a ninguém em particular e portanto ineficaz para produzir mudanças sobre a questão em discussão. È interessante ainda, assinalar seu fatalismo que parece encobrir uma fonte de grande tensão, tanto que recomenda que não se deve pensar na riscos mas "Bota a cabeça pra funcionar" ocupada na construção e reconstrução do perdido sem avaliação da ameaça. Podería-se pensar em algo como que supersticioso onde o pensar nas possíveis desgraças pudesse atrair o mal.

iii) Possibilidade de Prevenir os estragos da enchente:

MARIA:

(prevenir) da enchente não, depende da prefeitura, dos órgãos lá, depende da prefeitura fica em cima do (loteamento) para fazer aquela obra ...

LUIS:

Mas eu achando que única coisa, uma coisa que depende da gente, é prestar atenção nos açudes, porque vão reconstruir, não pode reconstruir, tem que botar a boca no trombone se começar alguma obra lá .... Entende, por exemplo, acompanhar, aqui tem dois (vizinhos) ... ... não só eles acompanham isso ai não só a causa que a gente ta movendo contra esses quatro, essa quatro... propriedades, alem disso, eles acompanham a vamos dizer, como vai ser feita a obra para transformar isso numa área segura, (nomeia vizinhos) estão sempre em cima. Então isso depende da gente, acompanhar isso, cobrar... Agora fora disso não tem, o que, como fazer. 


\subsubsection{FAMÍLIA 5:}

Entrevista com uma jovem nomeada Eliane.

\section{A. Descrição Dos Fatos:}

ELIANE: estava dentro de casa na hora da enchente e seu depoimento foi bastante angustiado;

Tava chovendo muito naquele dia. Eu tava aqui na minha casa, tava eu minha mãe e meu tio, tava desempregada ... A hora que eu cheguei eu tomei a maior chuva e eu falei assim: - Eu vou chegá em casa, vou deitá, assistí televisão com essa chuva, né? Na hora que eu fui pra toma banho, a água do ralo começou a subir e aí até coloquei um paninho ali, não sei porque, eu coloquei minha roupa de novo, aí eu sai eu falei: - Mãe ta entrando água dentro de casa ... e aí minha mãe falou assim: - Ué? minha mãe saiu, olhô no muro e viu que tava cheio de água, até a metade do muro, a rua inteira... Aí na hora que ela chegô, a água já tava já pelo meu joelho, aí um menino veio gritar aqui na... no portão pra eu tirá o carro, aí ele tirou o carro e a água foi subindo... e еи peguei e fiquei aqui dentro. Aí, minha gatinha deu cria na época, daí eu fiquei muito preocupada com os gatinho, aí eu peguei o lençol assim e tentei salvá eles, só que tava, tinha correnteza dentro da minha casa, isso a água já tava no meu ombro, aí eu quase caí tentando salvar eles, aí eu fiquei desesperada. Fiquei chorando, aí voltei eles e coloquei em cima da cama só que achei que a água não ia subi tanto e dava pra salvá eles. ... é... subiu muito e eles morreram tudo. Aí que um dia né eu fiquei que chorando. Mas a água entrou aqui... Foi pra cima do teto.... Eu saí nadando pela janela né, que a janela tava aberta eu saí nadando pela janela. ... Eu senti, ah .... eu não senti medo de morrer. .. Minha mãe tava dentro de casa, ela também pegou e saiu nadando.... Meu tio também tava, todo mundo aqui nesse quarto, meu tio tava tentando colocar as coisa em cima assim, sabe? Pra tentá salvá alguma coisa ... As coisas tudo quebrando, tudo caindo, o guardaroupas virando... aí eu ficava agoniada. ... no dia que eu tava aqui, né, meu irmão chegou, ele nem (ligou) pra mim, ele olhou direto pra casa, ele desceu a rua: - E a casa? O que aconteceu com a casa? Aí eu falei assim: - Deixa eu 
colocar as cachorra dentro do seu carro. Não, não vai, porque não sei o quê. Falei: - Me leva pra casa da minha vó? Não, não vou te levar, que não sei o quê. Fui na casa da minha amiga, minha mãe falou assim: Pega a lotação aí e vai, fala que você não tem dinheiro, que você perdeu tudo e vai. Pega o ônibus, pede carona. Daí o pai da minha amiga me levou... aí eu peguei e saí e eles ficaram aqui...

B. Premissas:

i) Familiaridade com os antecedentes das enchentes, informações locais e pareceres técnicos:

Acho que não pode acontecer de novo, pelo menos acho que eu não vou estar aqui de novo, eu não quero, lógico, né? Mas se acontecer, eu já sei, eu já tenho na minha cabeça o que fazer... Se (em 96 teve uma enchente) nunca chegou nem aqui em casa ... Não lembro, porque nunca chegou aqui na minha casa, se chegou, eu lembro de algumas outras, mas foi tudo na rua, nas casas ali de baixo. Mas nunca foi que nem essa, que nem essa, jamais. ... Não, nunca.(na casa ninguém comentou de que uma poderia chegar aqui) nunca, nunca imaginei que ia chegar aqui.

Eliane tinha 10 anos em 1996 e poderia não se lembrar do ocorrido, mas é interessante assinalar que parece que esse assunto não é comentado em sua família ou ainda á comentado, mas ela mantém-se alheia a ele.

ii) Percepção da ameaça e da perda:

A noite né, eu ia tentá dormi eu não conseguia, porque eu fechava o olho, ficava imaginando aquilo, aquilo vinha na minha cabeça, vinha, vinha... Aí, nossa eu fiquei transtornada... fiquei super transtornada. ... : Aí ela vinha assim...mas foi mais por causa deles (os gatos), porque eu imaginava eles morrendo e eles nem... nem sabe nem percebe o que acontecendo nos arredor. Sei lá, me desesperava aí eu vinha aqui, eu perguntava: ... e os gato? Os gatos morreu Eliane. ... aí eu começava chorar desesperada, o mais desespero aí também, porque eu fiquei imaginando assim... Nossa, depois que eu me dei conta, imagina só se o guarda-roupa baixasse e ficava preso na 
janela e não desse pra eu sair. Eu ficava agoniada, sabe, vindo aquela água. ... É, e se o guarda-roupa tivesse, parasse aqui sabe, (mostra a janela) com a correnteza e não desse pra eu passar. Depois que eu pensei, mas no dia, eu não achei que ia morrer.... num passou nem por um minuto, que eu ia morrer. Nossa (chora), tinha alguma coisa assim, sabe, me apertando por dentro, eu só chorava, só chorava, só chorava, chorava, chorava, chorava, não parava de chorá. ... Sabe, depois daquilo (da enchente), eu falei pra quê? Sabe, a gente trabalha tanto, ... Que nem antes de eu ficá desempregada daquela época, um ou dois meses antes, eu tava trabalhando no shopping. Tudo aquilo que eu comprei, acabou... Eu gostava tanto ..., sei lá, eu acho que era um pouco materialismo..., você perde até... o materialismo das coisas ... sabe, destrói, acaba tudo, falava assim: - O que aconteceu?... Tudo, tudo o que a gente tem é novo, assim novo! Que a gente ganhou... ou que comprou outro novo, aí oh! (mostrando os móveis e utensílios na casa).

Parece que a experiência traumática representada pelo impacto da perda e da ameaça à vida coloca-se como um empecilho ao desenvolvimento da compreensão sobre o ocorrido em suas múltiplas dimensões. De certa maneira, fala de si mesma e de sua alienação ao falar dos gatos.

\section{iii) $\quad$ Percepção do desamparo:}

Tem que, tem que ter algum tipo de atitude, né?... Acho que egoísmo, ... naquele dia mesmo eu tava conversando com um menino na igreja, (---) que morreram três pessoas ... ele falou assim: - Eu ia entrar na casa da mulher pra ver, só que na hora que eu vi, eu tava com o tênis novo, eu ia pisá naquele barro e aí eu voltei. Falei: - Olha como a pessoa é! E a gente, quanto tênis novo esse pessoal perdeu aqui... sabe? Foi muito egoísmo... Foi, teve gente morrendo ali e ninguém se preocupou em pisar no barro... e ...-Ai, que água nojenta..., mas tem coragem de entrar dentro da casa de novo, é assim, por isto que eu não gosto daqui, porque as pessoas são egoístas.... As que passaram, tá todo mundo tava todo mundo, tava todo mundo chorando aqui na frente (---) era um, acho que era muito egoísmo, lógico que teve muita gente que ajudou, mas ... entendeu. Pô era uma vida, uma pessoa todo, 
se eu vejo, eu vejo uma pessoa morrer na minha, nossa... saio chorando (---) nunca mais. É ... nossa! Na hora que o corpo caiu... é, no travesseiro, é que volta tudo ...

Parece que Eliane fala de seu desamparo, solidão e seu sofrimento, sem perceber em si condições de transformar os aspectos opressores.

iv) Percepção da transformação pessoal:

... porque depois desse, depois do que aconteceu com a enchente..., eu... fui procurar um psicólogo pra conversá, porque tudo o que acontecia naquela época, eu chorava, tudo. Eu fui entrando meio que em depressão, sabe? Eu não tinha vontade de me vestir mais, não tinha vontade de sair na rua mais, eu não tinha..., sabe? Tudo o que acontecia comigo, eu achava que era culpa da enchente... Eu não tinha roupa mais, então achava que era culpa da enchente... ... eu acho que foi pior depois da enchente.... Porque fica aquilo tudo, sabe, foi tudo aquele negócio. Nem sabia mais o que eu tava fazendo, sabe? Tava tudo sem... sem rumo... parecia que tudo, meu sonho tinha desmoronado, não tinha mais idéia pra nada, não tinha mais vontade de estudar, não tinha mais vontade de fazer nada... Eu queria voltar estudar, agora eu vou fazer academia, sabe? Eu quero voltar a ser como eu era $\underline{\text { antes... }}$

Tem chacoalhar a poeira e dar a volta por cima.... Não pode deixa nada abater, né? Eu falava assim: Ai ... eu via essas coisas na televisão e falava assim: Nossa, só acontece com os outros. (---) aconteceu comigo, aí eu vi o que é.... nunca imaginava, que pudesse acontecer. ... Tem é... eu tenho medo de dirigir, assim, eи fiquei muito medrosa, em tudo. ... (---) dirigia, dirigia moto, sabe? Aprendi. Fiquei com medo..., é... parei não tive (---) parei de estudar, e se eu vejo alguém, porque naquele dia tinha um monte de gente na rua e ninguém se preocupou em entrar pra pegar a gente ou gritar pra gente sair, todo mundo ficou olhando...(---) se eu vejo agora, alguém, sei lá, passando por algum perigo assim, eu já, eu já quero ajudar, entendeu, se eu vejo algum..., еи antes eu ficava parada, agora não, eu tenho que fazer alguma coisa, que nem aquele dia se eu tivesse ficado parada no lugar eu 
teria morrido, sabe tem que pensar, tem que fazer alguma coisa, se eu tiver, sabe num deu tempo, mas se acontecer de novo, isso... pensar, tem que fazer alguma coisa, se eu tiver, sabe num deu tempo, mas se acontecer de novo, isso... E eu não quero ficar..., de braço cruzado, se eu tiver que passar por alguma outra coisa... Eu vou, vou lutar pra ficar viva... Eu vou, vou lutar pra ficar viva... A gente tem que se manifestar, sabe? De alguma forma, tem que fazer alguma coisa, que nem o pessoal viu a gente aqui dentro e não fez nada, acho que se eu vejo, se tivesse... se fosse hoje se eu visse alguém, eu entrava e...

A contradição percorre quase todo o depoimento de Eliane. Em um momento afirma seu desespero e falta de vontade de reagir e dar continuidade à sua vida, e no momento seguinte, enraivecida, afirma o oposto de que agora está diferente e que vai "lutar para ficar viva". Parece que a elaboração da experiência traumática que poderia dar um sentido unificado a estas idéias antagônicas inspiradas por sentimentos igualmente contraditórios não se faz. Como se sua inserção no ocorrido fosse episódica e em planos paralelos que não se tocam ou quase nunca se tocam. Talvez o momento de encontro seja representado nesta sentença " $E$... nossa! Na hora que o corpo caiu... é no travesseiro, é que volta tudo .." e esta experiência è atualizada com emoções tão intensas que lhe rouba o sono e a descarga somática se segue e Eliane nessa hora só: "Nossa (chora), tinha alguma coisa assim, sabe me apertando por dentro, eu só chorava, só chorava, só chorava, chorava, chorava, chorava, não parava de chorá." 
1. Figura 20 - Vista da rua em local próximo a casa de Eliane, no dia seguinte.

2.

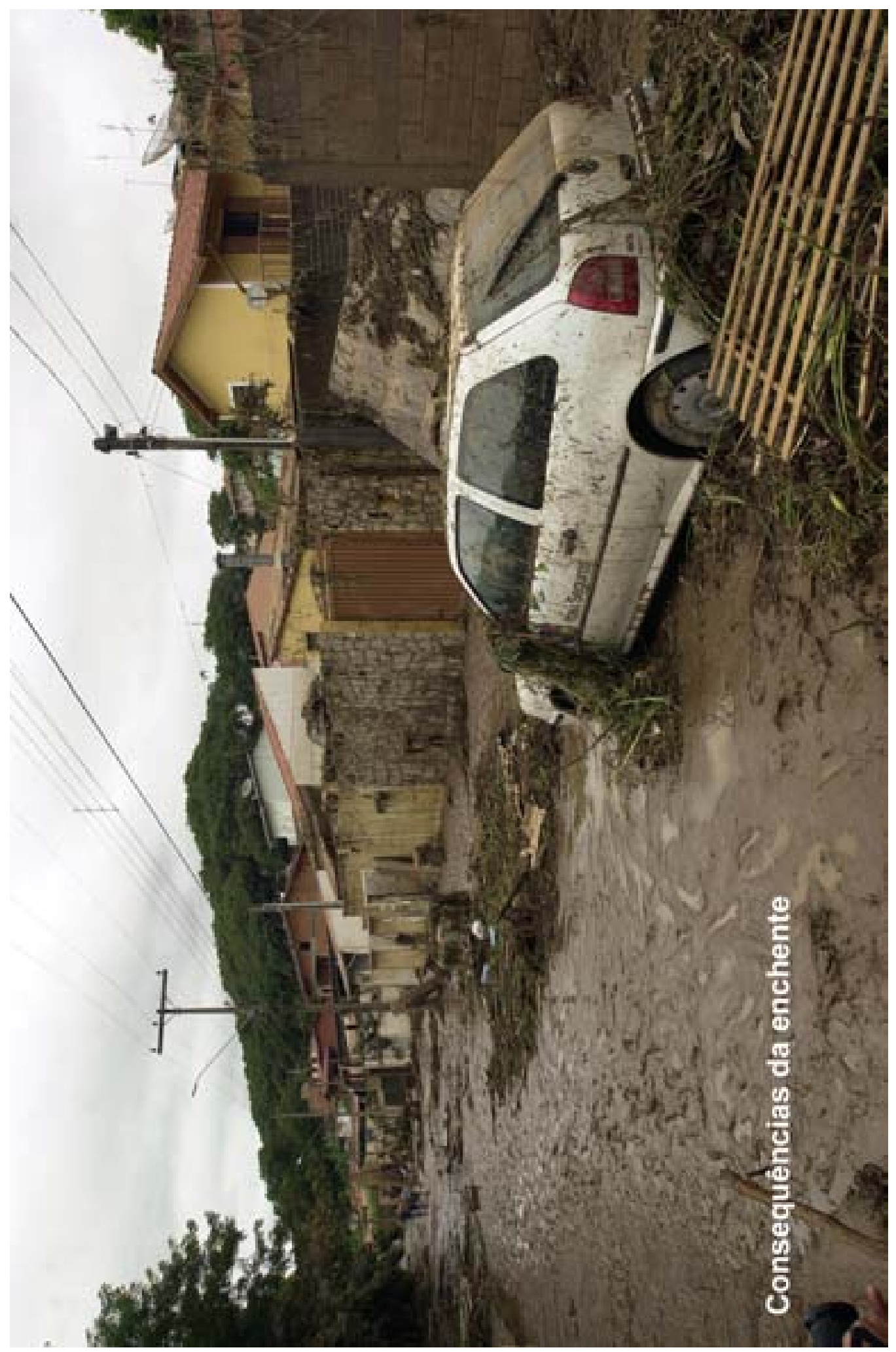


v) Percepção da vida familiar:

Aí no outro dia não sei porquê, depois que eu tomei um remédio, que tava muito nervosa uma (---) que meu irmão pegou e ... e ligou, né? Falou assim: Você tá bem? Até que ... perguntando assim pra mim, porque não é costume dele, sabe? Dele (--) pergunta: Oi, tá tudo bem? Não, é por isso que quando ele vem assim eu já me armo. ... Porque eu não conto os meus problemas pra eles, se eu estô chateada eu não conto, porque eu acho que não pode confiá, eu não confio..., Aí, depois daquela época todo mundo ficou brigando, aí meu irmão brigou comigo, daí meu namorado veio aqui e brigou com ele... sabe, foi uma bagunça.... Só queria fica só... só chorando, só em casa. Aí, meu namorado vê essas coisas, meu irmão pegando no meu pé e meu irmão brigando comigo. Porque eu já briguei muito com o meu irmão... a gente até foi pará na delegacia, por causa de briga. Sabe, brigando e ele ficava nervoso comigo, qualquer coisinha. Ele brigava com a namorada dele, batia em mim, me bateu, me bateu, me bateu. Uma vez ele me bateu, me deixou toda roxa... inteirinha roxa, aí foi um dia que eu procurei advogado, fui na delegacia e fiz B.O., porque eu não agüentava mais. Aí, quando ele me batia e falava assim: Você esqueceu o jeito que você levou aquela surra? Esqueceи?... Teve um dia que eи não agüentei mais, teve um dia que... foi assim..., desse jeito eu não vou ficá mais. Imagina que um homem vai me batê desse jeito, me derruba no chão e me chuta, imagina... Nunca, nunca eu não vou deixá (---) fazer comigo.

Todo este relato bastante emocionado parece revelar uma dinâmica familiar perturbada pela experiência da enchente e assim, como na moradia ainda está bem evidente a destruição, nos corações e mentes das pessoas esta destruição se manifesta nos relacionamentos desconfiados e embrutecidos. Estas manifestações são características de um modo de funcionamento primário que busca uma descarga imediata, catártica das emoções, o que inibe uma elaboração simbólica da experiência com a atribuição de significados de acordo com o universo de valores desta família. 


\section{ARGUMENTOS:}

i) $\quad$ Escolha Do Local De Moradia antes da enchente:

Porque meи pai comprou terreno aqui, construiu e a gente veio morar aqui, que antes eu não morava. Eu gosto de ver gente, sabe? Eu gosto de estar com o pessoal, aqui não tem nada, aqui é cada um por si, gosto de conversar, chega a noitinha (---), senta na calçada, sabe? Conversar, sabe? Eu não gosto de ficar sem nada, cabeça vazia, vamos assistir ao Ratinho...(programa de TV) ... Aí construiu e a gente teve que vir morá aqui, né, como aqui não (--) de casa então aqui meio aqui (---) sei lá sabe, eu nunca gostei daqui.... Faz uns três ou quatro anos que ele (pai) foi lá pra Pernambuco, foi ele, a mulher dele e minha irmã.

Não se coloca na decisão, como se nada tivesse a ver com isso e está alheia às implicações da escolha do local e da permanência.

ii) A decisão de voltar para morar no mesmo lugar depois da enchente:

Aí, toda vez que começa a chover eu começo a chorar e à noite eu não durmo...sabe, fico mais... Naquela época não, naquela época não, (---) se a gente sair daqui e gente vai pra onde? Eu acho que isso (enchente) não acontece mais, porque foi devido às... às... às represas que estouraram, fazer o quê, não tem pra onde ir, um dia vou sair daqui porque eu nunca gostei de morar aqui.... Moro aqui há mais de 10 anos, eu nunca gostei de morar aqui.... eu não gosto das pessoas daqui, eu não converso com ninguém, sabe? Não, eu falei assim: Eu não quero voltar aqui pra essa casa porque eu não gosto de morá aqui por causa da enchente, sabe? O muro caiu, a parede daqui do quarto do meu irmão(caiu) e ficar morando numa casa assim (olha ao redor).

Manifesta seu medo, seu desconforto e seu sentimento de impotência para de transformar sua realidade.

iii) A percepção da volta para casa: 
Aí eu voltei, e a gente tudo (---) dor (---) apareceu mosquito tava parecendo um não sei o quê, sabe? Todo mundo dormindo meio que no quarto, sem porta, ventilador, nossa estava parecendo... estava horrível, o clima estava horrivel (---) tudo dormindo, com aquele colchão (---) cheiro horrivel daquelas roupas, sabe? Chegava um monte de roupa, a gente tinha que escolher roupa, eu falava assim: - Nossa, cadê minha roupa? E aí chegava a roupa de todo mundo, menos as minhas que levaram pra lavar... Assim, eu não salvei nada, eu queria as minhas coisas e não tinha. Ajudei a limpar uma pouco, só que quem mais fez foi meu irmão, minha mãe, veio o pessoal da igreja da minha mãe, ajudou eu não ajudei, estava até outro (---) é frescura... Ninguém percebeu do jeito que eu tava, ninguém, ninguém, ninguém, ninguém viu o jeito que eu tava... Parecia que tava todo mundo, todo mundo bem menos que eu..., e ninguém sabe, se importava. (repete com ressentimento o que acha que os outros falavam dela) - Ela está mal, por isso que ela não vem. É frescura, é frescura, sabe onde já se viu isso, é aconteceu isso com a casa e ela não quer vir limpar. Ela (sua mãe) queria que eu ficasse aqui, acabou a água, né, pra ajudar, acabou a água, ficou uma semana com aquele barro... E ela queria que eu ficasse aqui, o dia inteiro, com câmeras do "Cidade Alerta", do não sei o quê (---)...ah, imagina. Quem dá entrevista dá na rua, foi ela, deixa ele entrá dentro de casa... achei isso muito ruim, já tava to (---), depois me contou, aí que saiu em tal jornal, que não sei o quê., ... Danô (---) que tinha sobrado alguma coisa, eu falei: - Eu não queria tê saído não... aquela desgraça, eu queria ficar na minha..., tava (sua mãe) mais preocupada em aparecê do que.... Do que que eu tava sentindo.

Parece que Eliane ainda não "voltou" para casa. Mantém-se alheia ao processo de reconstrução do morar e das relações familiares. A experiência da enchente imprime outro rítmo ao seu habitat e parece que ela não encontra em si mesma recursos para esta empreitada. Há um embotamento de sua criatividade dirigida a atribuição de significados à experiência o que se reflete em s auto excluir da situação. 
iv) Possibilidade de Prevenir os estragos da enchente:

Acho que não, pelo menos acho que eu não vou estar aqui de novo, eu não quero, lógico, né? Mas se acontece, eu já sei, eu já tenho na minha cabeça o que fazer... Pegar e sair daqui, pegar primeiro os gatos e sair correndo, então quando está chovendo eu deixo eles tudo perto de mim, (---) fica aqui, outro fica aqui, outro fica aqui.(mostra na cama).., ( quando chove) $\underline{E}$, à noite eu acordo, durmo, mas aquele sono leve, né? Não durmo como se fosse os outros dias... Medos assim, mas eu acho que um dia eu vou perder esse medo, só tem isso aqui vou encarar o medo, né? Eu tenho, eu tenho que ter por... acima de tudo eu tenho que ter força própria, não adianta nada eu ficar chorando pelos cantos me..., tomando remédio e não ter força própria. : (---) tipo assim entrar em depressão, não mais eu não posso viver em depressão, eu tenho que fazer alguma coisa, porque todo mundo aqui em casa fala que é bobeira, que é besteira que depressão não existe, acho que qualquer pessoa, aí quando minha mãe ficou sabendo que você vinha, perguntou pra quê? Pra quê? Aí eu falei assim: É coisa minha ... Então, acho que o problema tá ca gente, a gente tem que sabê resolvê... Não é, não é essas coisas, tem que saber resolver, encarar os problema de frente, senão...

Eliane parece querer contrapor ao medo uma segurança de que controla sua vida "eu não vou estar aqui”" e em seguida parece que é tomada pelo temor e fala da depressão e de sua luta interior para vencer o sentimento de derrota e perda. Nesta luta busca uma estratégia de convencimento e demonstra seu sentimento de solidão face o futuro. Esta situação afetiva é a evidência da experiência traumática caracterizada pela intensidade sensorial que se impõe sobre a consciência demanda uma atribuição de significado. Vivências primordiais de desamparo são atualizadas e nesta experiência atual e provocam esta agonia evidente no depoimento de Eliane.

v) À Guisa De Avaliação

É, nunca, mesmo quando eu tava lá dentro da enchente, ... eu num vou morrer, num passou pela minha cabeça que eu vou morrer. É, depois que eu me dei conta que eu poderia ter morrido, porque eu ia dar um jeito de não morrer... Entendeu, eu vou lutar até minhas últimas forças para não morrer... 
eu acho que, que tem muito chão ainda pela frente, tem muito chão até esse dia,... essa vida é ingrata que não sei o quê. Porque foi uma surpresa mesmo, eu não sabia o que fazia, pra onde ia, mas eu sabia que eu ia saí de lá.... Ah, eu parei de pensar nisso, às vezes eu nem, nem gosto muito de falar sobre isso tudo (---) lógico, mas assim eu não fico na rua, que nem minha mãe, todo mundo que ela conhece, ela conta, conta como se fosse uma coisa ótima, com (---) não porque (---) tá bem (---) vezes às vezes não tá, eu não conto, sabe? Pra mim foi uma coisa do passado.... Aí, eu não gosto, por mim ... ficou aí, como eu odeio ser pobre.... Aí, se eu fosse rica eu não estaria nessa situação, nessa coisa, sabe? Num (---) é bobeira, sabe querer ser... ter dinheiro que não sei o quê, não que eu vou sê se não que eu vou sê mais feliz, ... aí se algum dia eu tiver dinheiro, vou fazer isso, isso, isso, fazer tal coisa (--) tal coisa ... Eu queria muito voltar a estudar pra tudo aquilo. Sempre fui assim, sempre tive um objetivo... Sempre eu lutava, eu ganhava, eu ia fazer um curso, todo o curso que você faz nunca sai do mesmo jeito... Então eu aumentava, tudo pra ter auto-estima, sabe? Essas coisas, eu... eu sempre tive objetivo, ... , antes eu pensava, agora eu já não penso mais nisso, e como é que eu vou, tá? Ah, sei lá, pra quê, pra quê eu pensar. Mas, eu tenho que voltá a ter esses objetivos, (---) daqui a quatro anos, eu vou tá casada? Estar trabalhando, aonde? Trabalhando no quê, ganhando tanto? É, acho que sempre tem que um objetivo, porque fica, deixa a vida me leva, não vai pra lugar nenhum.. Agora, depois disso fiquei tímida, tenho vergonha de tudo, qualquer coisa fico vermelha, depois da enchente parece que eu me fechei pro mundo e antes parece que não era assim..., antes eu não tinha vergonha, falava em público, sabe? Técnico, eu fiz um curso no SENAC, que tinha que falá em público, sabe? Num..., agora vai vê hoje, eu morro de vergonha, mas eu acho que foi isso da enchente, que eu fiquei assim, que eu me fechei muito... : E, eu queria voltar do jeito que eu era antes, tanto que, quando alguém me pergunta quantos anos eu gostaria de ter, eu queria ter quinze, eu queria voltar e fazer tudo..., ter passado batido.... É, não ter passado (pela enchente), pra ser do jeito que eu era, se eu falasse, se eu falasse assim: - Eu vou fazer tal coisa. Eu fazia.... Independente se eu fosse sofrer ou não, eu fazia.... um pouco de determinação... Agora, eu não tenho...é difícil...voltar a 
ter a determinação que eu tinha, voltá a fazer as coisas que eu fazia, da forma que eu fazia. ... Eu tenho que ocupar a minha cabeça, agora eu acho que eu vou melhorar... eu gosto de trabalhar em shopping... eu prefiro trabalhar no feriado, do que ficá aqui olhando pro nada... agora eu acho que eu vou melhorar, tá fazendo academia, fazendo as coisas, conversando com um monte de gente, andando.

Neste trecho do depoimento Eliane faz um balanço da experiência e atribui a si mesma e sua família a culpa por seu sofrimento, ao referir-se a sua vergonha em ser pobre e ter esta condição exibida pela situação da enchente. Esta avaliação reflete um pensamento fechado em si mesmo (narcísica) de ordem puramente subjetiva, que se interpõe entre Eliane e fatos do mundo real, inibindo a realização de um processo avaliativo que contenha a complexidade da experiência. $\mathrm{Na}$ impossibilidade desta compreensão abrangente, que lhe permita atribuir significado a experiência como um todo, parece que opta pela alienação buscando racionalizações do tipo auto convencimento de que agora tudo vai melhorar.

\subsection{Instauração do Paradoxo:}

Pretende-se nesta parte do trabalho um alinhavo da discussão das informações analisadas, buscando avançar na compreensão das razões psico - afetivas para o fenômeno observado de não comunicabilidade da experiência traumática através da explicitação do pensamento paradoxal.

O paradoxo se enuncia quando um conjunto de premissas, aparentemente não controversas geram conclusões contraditórias e inaceitáveis. Para resolver um paradoxo é necessário demonstrar-se que há nas premissas uma falácia oculta, ou que o raciocínio esta equivocado, ou ainda que a conclusão aparentemente inaceitável pode ser tolerada. (Blackburn, 1996). No capítulo anterior, a análise dos depoimentos leva a enunciação de conclusões paradoxais, no sentido de estar presente em todos os depoimentos, em diversos níveis de elaboração, a descontinuidade da sintaxe lógica entre as razões para a escolha do local de moradia, a descrição da experiência traumática e o argumento que leva à decisão de voltar ou permanecer no mesmo local de moradia, podendo-se afirmar que há uma incomunicabilidade entre estes elementos que compõem a decisão. Quando da escolha do local de moradia verifica- 
se a imposição de razões de ordem afetiva sobre qualquer outra razão de ordem econômica ou social. Mesmo que estas razões existam, e certamente existem, elas não foram explicitadas como variáveis no processo de decisão ${ }^{21}$. As pessoas relatam que foram atraídas pela proximidade com a família, pelas qualidades locais de tranqüilidade, beleza, paz, onde o córrego São Quirino é um elemento importante na percepção destas qualidades, sendo considerado responsável por atrair os pássaros, amenizar o calor, integrar uma reserva ecológica, formar um cenário bucólico e outras características deste teor. Quando confrontadas com a experiência da inundação que representa uma ameaça real e concreta a um estilo de vida, que no limite chega a morte, parece que estas vítimas se esquivam de estabelecer uma clara e direta relação entre o fato ocorrido e uma necessária revisão, porém dolorosa, de seus valores mais profundos e cerne de sua identidade, que poderia levar a uma transformação do ambiente seja pela implantação de medidas preventivas, seja pela troca do local de moradia. Este processo de esquivamento parece apoiar-se em dois tipos de raciocínios, por um lado a redução da magnitude de suas perdas pela construção de justificativas religiosas, missionárias e mágicas e por outro a busca de um culpado que no caso parece recair sobre os "fazendeiros" rio acima que construíram açudes para seu "lazer e desfrute". Essas racionalizações parecem afastar o foco da discussão de fatos reais e concretos que aconteceram, tais como: a intensidade da chuva no dia 17 de fevereiro de 2003 que foi atípica, representando o maior volume de chuva nos últimos 103 anos; a vazão do córrego sob a linha férrea que é estrangulada e pode ser bloqueada ou assoreada novamente; e as intervenções no córrego acima do bairro Parque Imperador onde todas têm autorização do $\mathrm{DAEE}^{22}$, como pode-se ver na Tabela 1. Deve-se ainda observar que atualmente o córrego permanece assoreado e grande parte do entulho que desceu o córrego e entupiu os dutos de vazão e provocou a inundação, ainda se encontra no local como

\footnotetext{
${ }^{21}$ Os depoimentos foram colhidos de forma livre sem nenhuma sugestão por parte da pesquisadora. A única questão que podería-se colocar, seria que o fato da pesquisadora ser psicóloga e pudesse ter influído na vontade dos entrevistados em revelar suas razões subjetivas em preferência a qualquer outra.

${ }^{22}$ No Estado de São Paulo cabe ao DAEE o poder outorgante, por intermédio do Decreto 41.258, de 31/10/96, de acordo com o artigo $7^{\circ}$ das disposições transitórias da Lei 7.663/91. Se uma pessoa quiser fazer uso das águas de um rio, lago ou mesmo de águas subterrâneas, terá que solicitar uma autorização, concessão ou licença (Outorga) ao Poder Público. A outorga de direito de uso ou interferência de recursos hídricos é um ato administrativo, de autorização ou concessão, mediante o qual o Poder Público faculta ao orgado fazer uso da água por determinado tempo, finalidade e condição expressa no respectivo ato.
} 
se a espera de outro temporal que poderá provocar nova catástrofe, como pode-se ver nas Figuras 21, 22 e 23 a seguir. Portanto, para avançar nesta questão da verdade consensual sobre o acontecido teríamos que estabelecer um critério de interpretação do enunciado aparentemente contraditório nos depoimentos. Talvez pudéssemos retomar a questão levantada anteriormente neste trabalho de que a avaliação da situação de risco é absolutamente subjetiva e dependente da leitura dos fatos e evidências circunstanciais levadas em conta pelo sujeito. Entretanto, para o sujeito que decide não está, de maneira nenhuma óbvio, que sua avaliação é principalmente subjetiva e que os fatos da natureza de fora colaboram nesta equação a partir de uma hierarquização criteriosa das condições de inclusão, a partir do sujeito. Fica-se com a impressão de que a complexidade do fenômeno perceptivo que envolve o sujeito, o mundo e suas inter-relações não é acessível por uma psicologia da consciência, mas pode ser melhor esclarecido pela concepção do eu dividido na psicologia do inconsciente apresentada pela psicanálise. 
- Figura 21. Situação, em junho de 2004, de escoamento do córrego sob a linha férrea

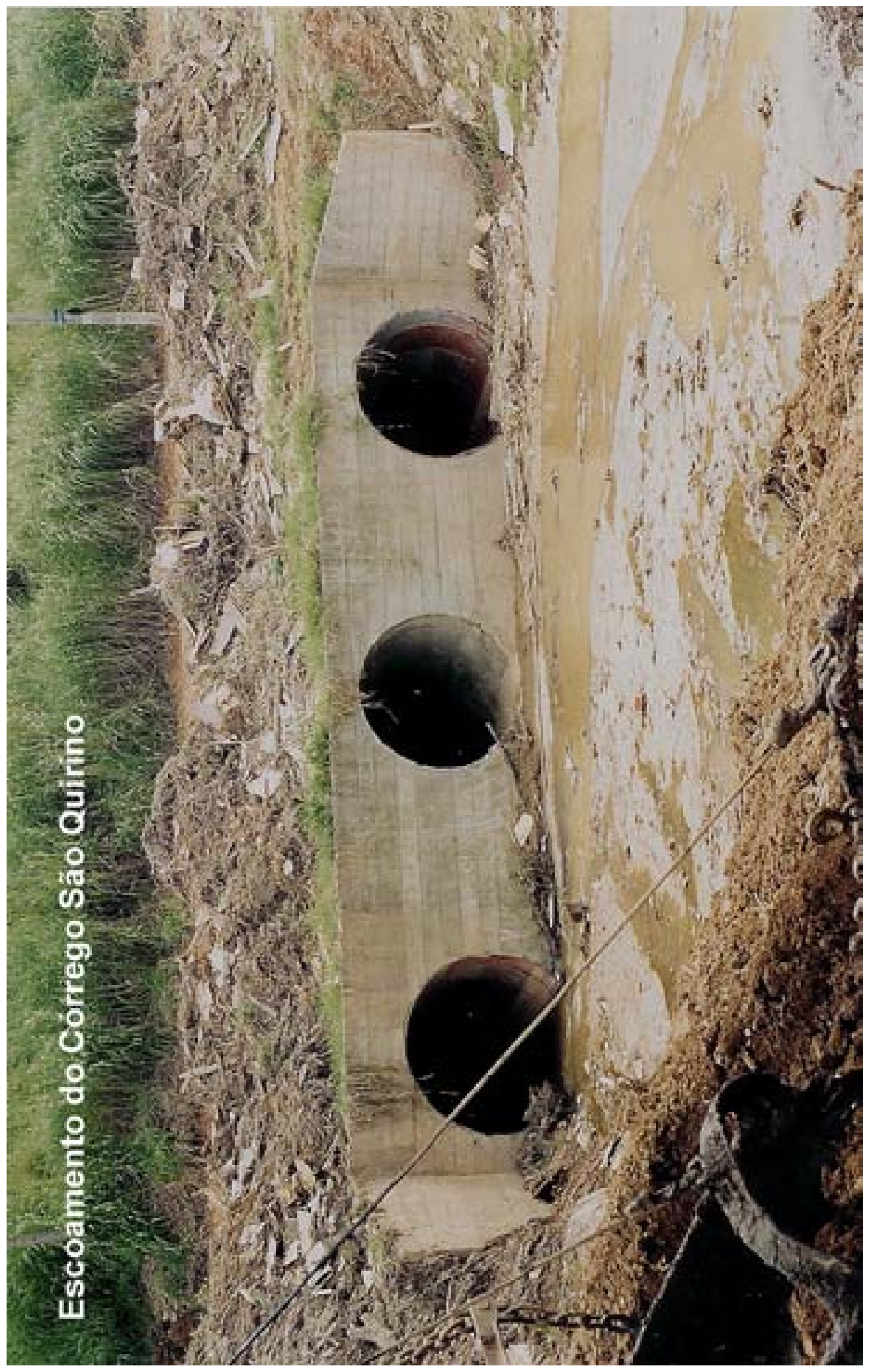


Figura 22 . Situação do entulho a montante da rua Altimira de Souza Pinto.

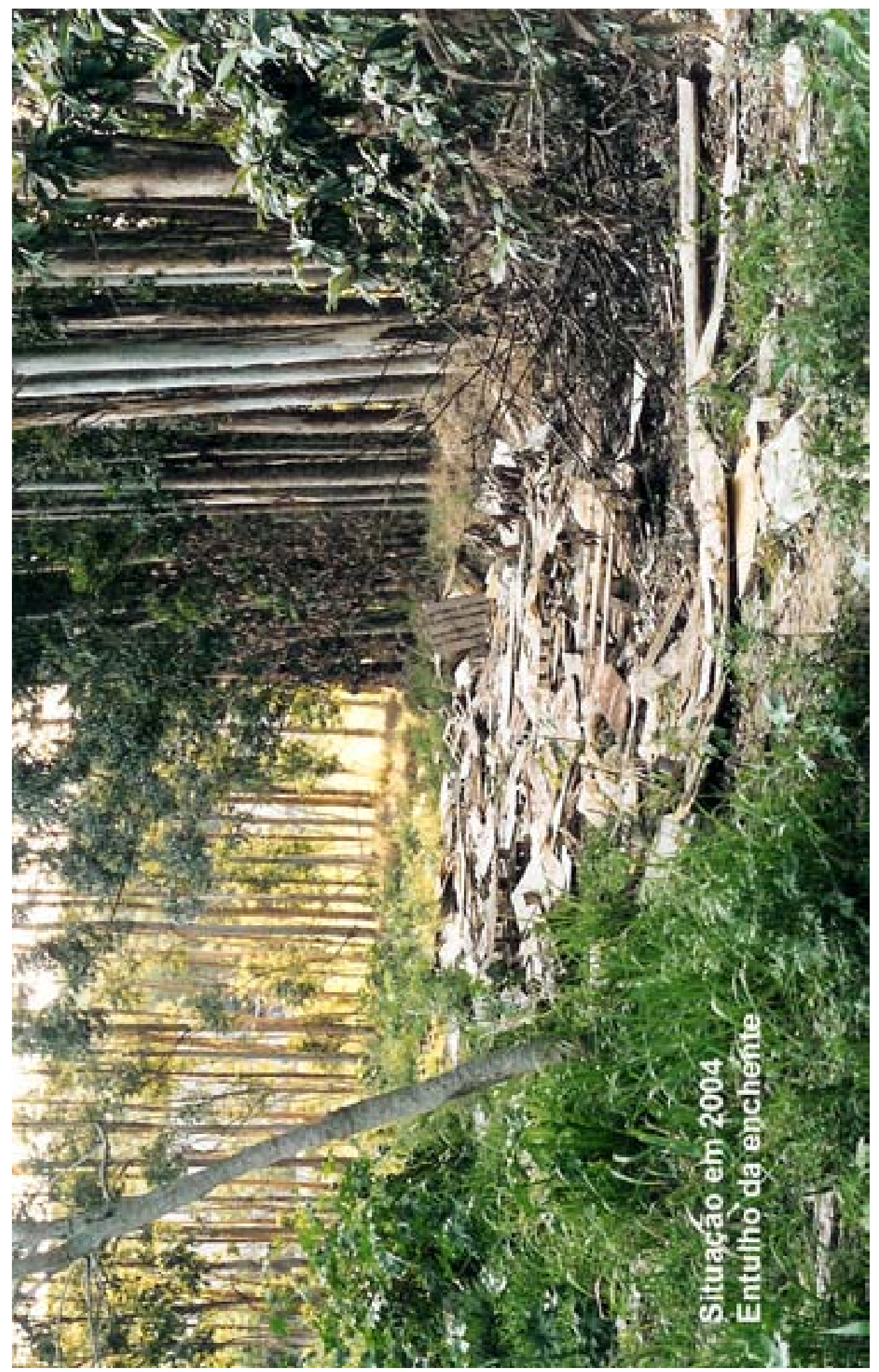


Figura 23. Situação, em junho de 2004, de assoreamento no córrego São Quirino

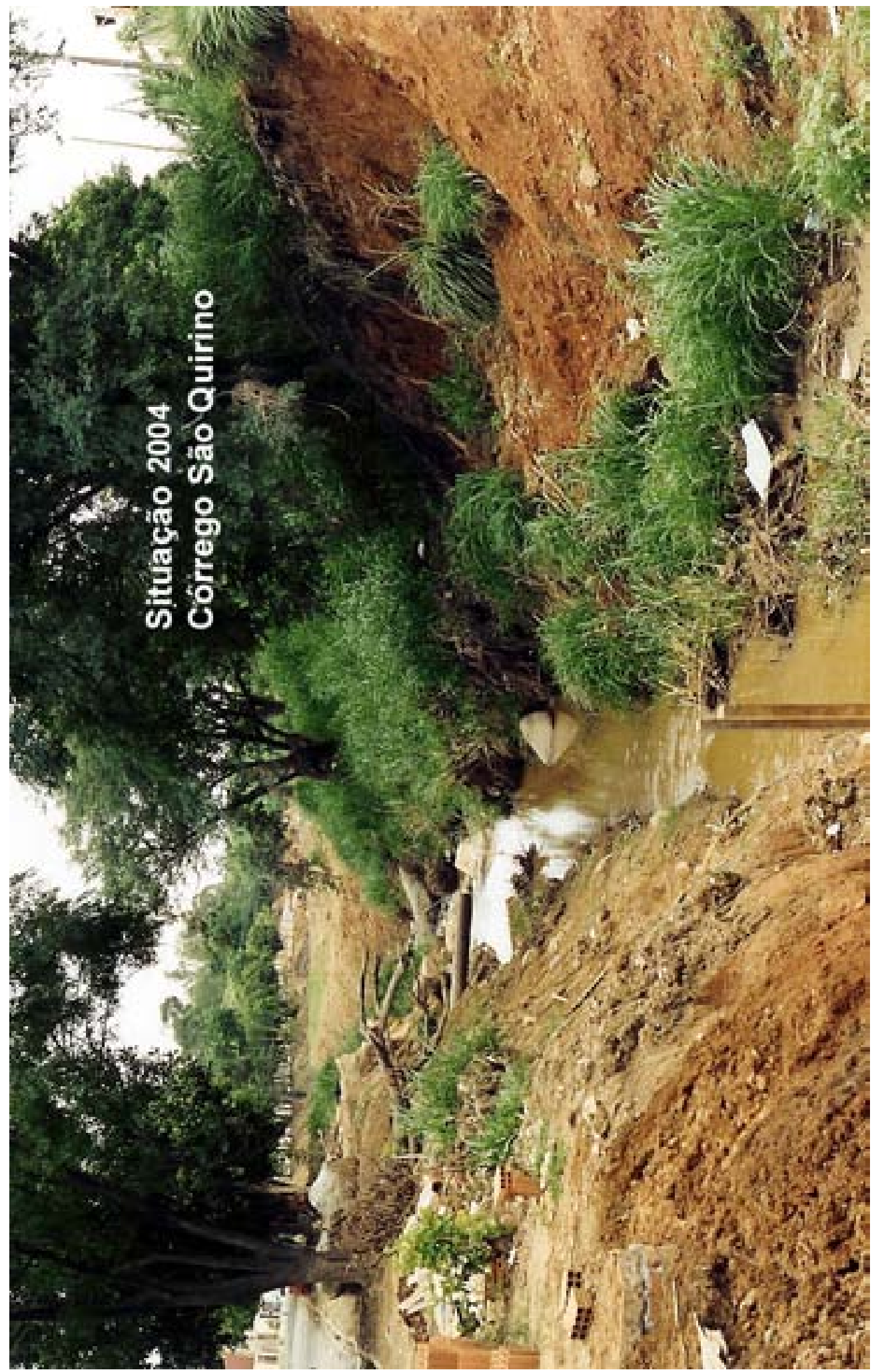


- O processo de compreensão do mundo real passa pela sensibilização de nossos órgãos sensoriais, pelas qualidade da experiência, mas pela atribuição de sentido a cada uma das partes, que será interpretada na compreensão do todo. Nesse sistema o novo está sempre ligado ao velho, onde as idéias antigas que a percepção do novo se ancora na atribuição de sentido. A cada nova experiência toda a massa de informação anterior é atualizada e rearranjada e passa a adquirir um sentido lingüístico através da linguagem de nossas percepções e ligações. As impressões sensoriais primárias estabelecem relações entre si, que são reproduzidas intrapsiquicamente o que leva a compreensão do mundo externo e abre a possibilidade de avaliação e alteração de certas variáveis. Torna-se assim de fundamental importância a compreensão deste funcionamento psíquico que atribui realidade ao mundo externo. As pulsões ${ }^{23}$ primitivas (eros e destrutividade) operam no inconsciente a um nível primário de satisfação imediata, pela transformação somática combinada com alguma transformação no mundo externo. Este imediatismo pode freqüentemente levar a perigosos conflitos com o mundo externo e no limite, à extinção do eu. Os processos do inconsciente (processo primário) diferem dos processos da vida intelectual e emocional conscientes e não estão sujeitos às restrições críticas da lógica. A incompatibilidade entre o inconsciente e o mundo externo requer a permanente intermediação do eu, que funciona (processo secundário) como um radar com dois campos de observação o mundo interior inconsciente e mundo exterior realidade. $\mathrm{O}$ eu faz a passagem da representação coisa para a representação palavra pela interpolação entre a exigência colocada pela pulsão e a ação que a satisfaz, o "pensamento que após orientar-se no presente e avaliar experiências anteriores, se esforça, mediante ações experimentais, por calcular as consequiências do curso de ação proposto". (Freud 1940) Esta capacidade de avaliação acompanhada do processo de tomada de decisão pelo eu é o que se chama de princípio de realidade. Dessa maneira o eu é governado pela busca da segurança e é ameaçado nesta tarefa, tanto pelas incríveis forças da natureza contra as quais é muitas vezes impotente como pelas poderosas forças do inconsciente, face as quais, também é muitas vezes impotente. $\mathrm{O}$ eu para manter-

${ }^{23}$ Pulsão, é um conceito desenvolvido por Freud ao esboçar a psicanálise, como um impulso limítrofe entre o somático e o psíquico. A pulsão é responsável pelo eterno movimento do eu no sentido da 
se íntegro precisa defender-se destas demandas em conflito, a que vem do inconsciente e a que vem do mundo externo e defende-se agindo sobre o único sistema sobre o qual tem algum controle, a percepção e a atribuição de sentido ao percebido. A experiência primordial de desamparo do eu refere-se a diferenciação entre eu e não eu inicialmente o não eu representado pelas figuras parentais e posteriormente equacionada pela introjeção das figuras paternas no superego, embora esta instância nem sempre seja capaz de proteger o eu destes dois perigos a sua integridade. A sensação de desamparo tem fator decisivo na resolução do conflito e cria as condições necessárias a clivagem do eu. $\mathrm{O}$ eu entretanto precisaria rapidamente aumentar seu repertório de intelectual para poder atribuir significados às pulsões emanantes do id e as tensões da realidade. Este processo manteria as pulsões reprimidas retardando sua satisfação até que uma correta avaliação da realidade fosse feita e pudesse ser tomada a melhor decisão no sentido da ação mais adequada tanto a satisfação da pulsão como da manutenção da integridade do eu. Ora, esta não é uma tarefa banal principalmente quando a realidade torna-se excepcionalmente penosa ou que as pulsões se intensificam extraordinariamente e nestas circunstâncias em que o ego é submetido a reivindicações rivais vê-se impossibilidade a permanecer em uma posição conciliatória e ocorre uma clivagem do eu. Esta clivagem se manifesta como abandono da realidade e a criação de construções delirantes com afinidade com as pulsões do id e um desligamento da realidade. Para que esta posição seja bem sucedida o ego nega a percepção sensorial e apega-se a uma idealização e toda a função de avaliação intelectual da realidade e de tomada de decisão se vê comprometida. (Freud, 1940)

ligação com o mundo externo ao eu, para alcançar sua satisfação. 
Tabela 1 - Situação legal das intervenções no córrego São Quirino



$\frac{8}{8}$

है

ga

8

星

응

퓸

远

里

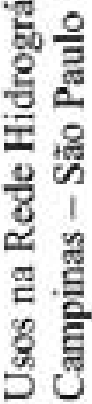

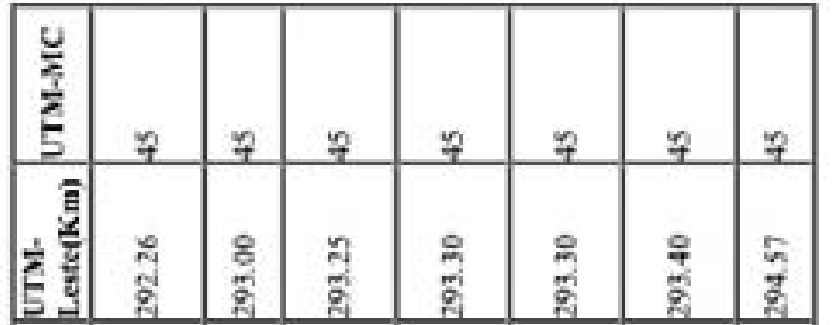

\begin{tabular}{|c|c|c|c|c|c|c|c|}
\hline 亮 & $\begin{array}{l}q \\
\mathbb{R} \\
\overrightarrow{2}\end{array}$ & $\underset{5}{\stackrel{7}{5}}$ & $\frac{5}{\frac{5}{5}}$ & $\frac{8}{5}$ & $\frac{\infty}{2}$ & $\frac{8}{5}$ & $\frac{2}{g}$ \\
\hline
\end{tabular}

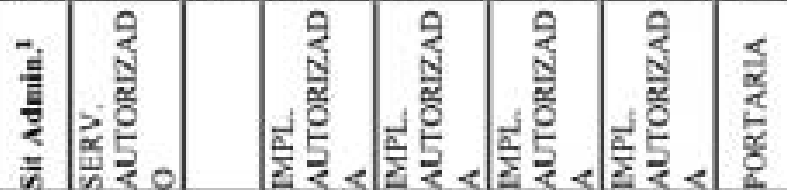
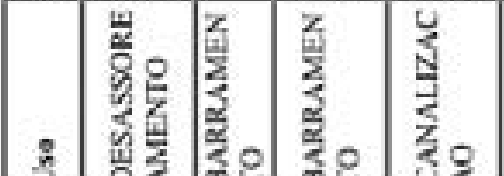

嵌

离

殸

焉

3

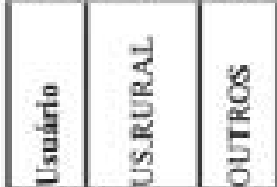

总 竞

\begin{tabular}{|c|c|c|}
\hline 童 & 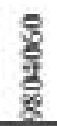 & 采 \\
\hline
\end{tabular}

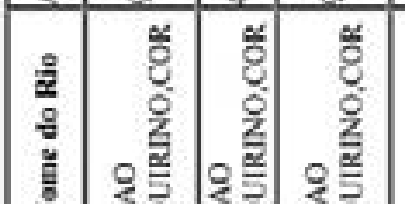

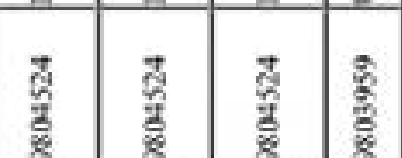

\begin{tabular}{|c|c|c|c|c|c|c|c|}
\hline 施 & 8 & 옹 & \& & $\frac{9}{1}$ & 吕 & 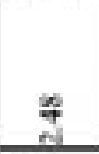 & $\begin{array}{l}8 \\
\text { vi } \\
\text { vis }\end{array}$ \\
\hline $\begin{array}{l}8 \\
8 \\
8 \\
8\end{array}$ & 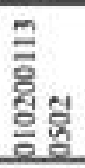 & 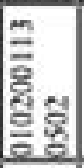 & 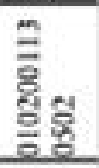 & 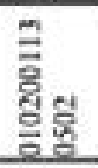 & 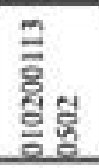 & 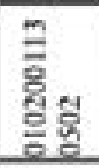 & 产 \\
\hline & & D & & 구 & $n$ & 10 & \\
\hline
\end{tabular}

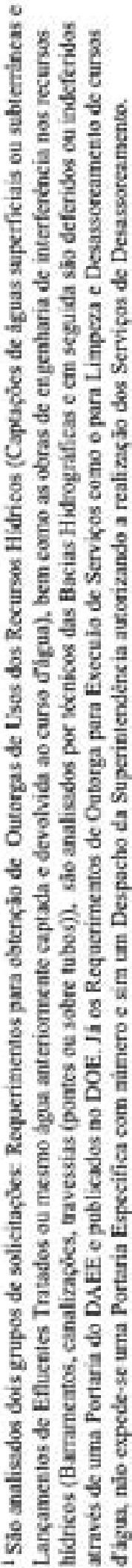


Tabela 1 - (continuação)

\begin{tabular}{|c|c|c|c|c|c|}
\hline$y$ & $\underset{x}{a}$ & $\because$ & $\because$ & 4 & $\because$ \\
\hline $\bar{z}$ & 号 & है & $\begin{array}{l}\not{*} \\
\stackrel{2}{2}\end{array}$ & 递 & है \\
\hline$\frac{5}{8}$ & 贵 & 율 & $\frac{8}{2}$ & है & $\frac{8}{8}$ \\
\hline है & 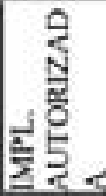 & 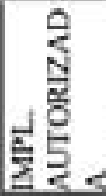 & 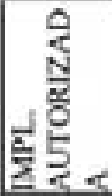 & 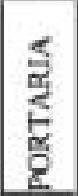 & 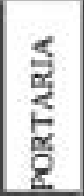 \\
\hline 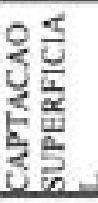 & 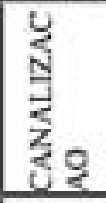 & 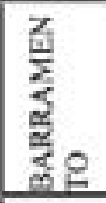 & $\frac{5}{3}$ & 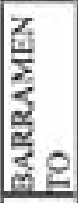 & $\frac{5}{\hbar}$ \\
\hline$\frac{U}{\alpha}$ & 氹 & ? & है & & 造 \\
\hline $\begin{array}{l}\frac{3}{3} \\
\frac{3}{3} \\
\frac{3}{3}\end{array}$ & $\frac{a}{5}$ & 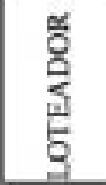 & $\frac{0}{5}$ & $\begin{array}{l}\frac{5}{2} \\
\frac{5}{3} \\
\frac{z}{z} \\
\underline{z}\end{array}$ & $\frac{8}{5}$ \\
\hline $\begin{array}{l}\frac{8}{2} \\
\frac{8}{8} \\
\frac{8}{5}\end{array}$ & $\begin{array}{l}\bar{y} \\
\text { जै } \\
\text { \% }\end{array}$ & 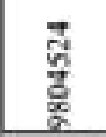 & 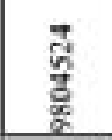 & 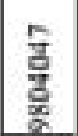 & 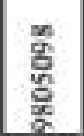 \\
\hline 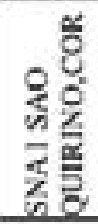 & 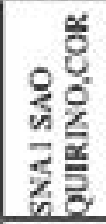 & 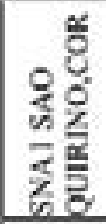 & 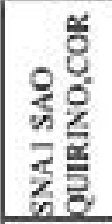 & 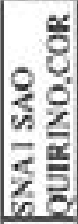 & 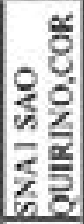 \\
\hline 8 & 8 & $\frac{1}{8}$ & है & 8 & 8 \\
\hline 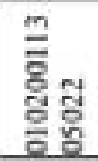 & 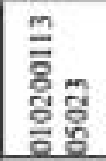 & 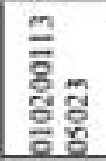 & 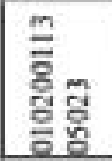 & 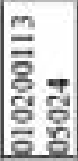 & 产 \\
\hline & 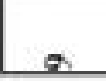 & $\stackrel{ }{ }$ & - & $\simeq$ & 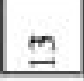 \\
\hline
\end{tabular}




\section{CONSIDERAÇÕES FINAIS:}

No desenvolvimento deste estudo verificou-se a não comunicabilidade da experiência traumática no sentido da não inclusão na construção da decisão pós facto da apreensão crítica do acontecido. Esta constatação implica na constituição de rtisco para o sujeito seja a nível objetivo ou subjetivo. A comunidade estudada passou por uma inquestionável experiência desta natureza, quando este bairro classe média de Campinas, que em 02 de fevereiro de 2003 uma inundação de proporções trágicas. Nesta investigação procurou-se entender os antecedentes do evento no sentido da caracterização do trágico, um destino sem possibilidades de ser alterado pela racionalidade, conforme abordada na conceituação de risco apresentada anteriormente neste trabalho. Verificou-se que estava e ainda está no presente, a disposição daquela comunidade um conjunto de informações sobre o comportamento anterior do córrego que poderia ter-se convertido em estratégias de prevenção e planejamento de enfrentamento do risco, que poderia ter salvo aquelas vidas e minorado as perdas da enchente. Buscou-se também a compreensão dos antecedentes pessoais daqueles indivíduos, seus ideais, seu modo de vida, suas opiniões enfim aquilo que Giddens(1991) menciona como estilo de vida, significando o conjunto de valores que sustentam seu processo de tomada de decisão sobre fatos essenciais na vida, tais como o local de moradia, o relacionamento familiar e outros aspectos que definem um estilo de vida. Trata-se de uma arqueologia do processo de decisão, o perscrutar a fundamentação das decisões e verifica-se que sujeito, com toda esta carga de subjetividade, está imbricado na compreensão da verdade intrínseca na experiência sendo impossível a posição de observador isento, como quer a ciência

neo-positivista. A partir deste mergulho em profundidade nos meandros da decisão verificou-se que este processo não se situa estritamente no campo da racionalidade 
fundantes da cultura racionalista, sendo apenas parte deste processo e esta é uma conclusão paradoxal, pois a racionalidade compõe uma totalidade compreensiva e se é parte então não é nada. $\mathrm{O}$ equacionamento deste paradoxo do ponto de vista da Lógica, pode ser abordado do ponto de vista da existência de um impedimento psicológico conforme apresentado na análise dos depoimentos. Este impedimento psicológico diferencia-se da ignorância cognitiva e portanto a dimensão lógica imbrica na condição psicológica. (Caorsi, 1994; Dor,1988).

Retomando-se a hipótese formulada anteriormente, da coexistência de dois planos de raciocínio que dialogam entre si de forma assimétrica, onde a racionalidade excluída se inclui como apêndice explicativo pode-se perceber que a percepção do fato é sempre uma interpretação da experiência. Ora o fenômeno perceptivo como Dor (1988) coloca, entre muitos que podería-se recorrer para ajudar a refletir esta sobre esta questão, traduz uma conciliação entre afetos impressionados pelos fatos que buscam nas conhecimento disponível na cultura elementos para a interpretação. Nesse sentido o fundamento da racionalidade é um paradoxo em si porque não há fato sem interpretação e não há interpretação que não seja intermediada pela experiência criando-se uma condição para que o diálogo, entre o estritamente psicológico e o estritamente lógico, seja de natureza psicossocial. Dor (1988) considera que é necessário o estabelecimento de um novo paradigma para esta questão paradoxal formulando a Teoria do conhecimento dividido - passando do ponto de visto do enunciado ao ponto de vista da enunciação que se contrapõe a Teoria do conhecimento na tradição neo-positivista, que se mantém ao nível do enunciado ou seja o observador não se inclui na enunciação da verdade. A verdade não esta fora do observador, nos fatos mas numa movimento dialético de busca da verdade que nunca se conclui. .

Por fim, deve-se acrescentar que esta arqueologia do processo de decisão permite concluir que a criação de uma política de gestão de recursos, através de uma estratégia participativa visando a instauração de uma cultura de segurança, deverá resguardar o espaço deste diálogo inconciliável entre os dois planos, racionalidade e racionalização garantindo a efetiva participação de um sujeito esclarecido com a consciência sobre si e o mundo externo estruturada na crítica, fundada na reflexividade sobre a experiência. 


\section{ANEXO A}

Descrição do processo de ocupação da cidade de Campinas/SP 


\section{Histórico da ocupação:}

A cidade de Campinas teve início por volta de 1720, como ponto de pousada das bandeiras que adentravam São Paulo pelo Caminho dos Goiases em direção às minas goianas. Meio século depois da abertura do caminho, o bairro das Campinas do Mato Grosso de Jundiaí (expressão que designava as matas fechadas) já tinha 300 moradores e 50 casas interligadas por um picadão, mas ainda muito isoladas em tempos chuvosos. O caminho teve posteriormente seu leito aproveitado, no século seguinte, pela ferrovia Mogiana. Na segunda metade do século XVIII, ganhava forma também uma outra dinâmica econômica, política e social na região, associada à chegada de fazendeiros procedentes principalmente, de Itú, Porto Feliz, Taubaté, que buscavam terras para instalar lavouras de cana e engenhos de açúcar, utilizandose para tanto de mão de obra escrava. Foi por força e interesse destes fazendeiros, ou ainda, por interesse do Governo da Capitania de São Paulo, que o bairro rural do Mato Grosso se fez transformado em Freguesia de Nossa Senhora da Conceição das Campinas do Mato Grosso (1774); depois, em Vila de São Carlos (1797), e em Cidade de Campinas (1842); período no qual as plantações de café já suplantavam as lavouras de cana e dominavam a paisagem da região. $\mathrm{O}$ povoamento efetivo começou com a chegada de Francisco Barreto Leme, entre 1739 e 1744 que, juntamente com família e conterrâneos, veio a se instalar em terras adquiridas de uma sesmaria. No mês de maio de 1774, o então governador Morgado Mateus outorgou a Barreto Leme a fundação do núcleo e estipulou algumas medidas urbanísticas básicas para o local. O cultivo do café prosperou na região devido às excelentes condições da terra roxa oferecidas à agricultura que aliadas a conjunções internacionais fez da década de 1840 colocar o café como primeiro produto de exportação do Império. Em 1842, é reconhecida nas Campinas do açúcar uma configuração urbana, outorgando-se à Vila o status administrativo de Cidade. No 
final da década de 1850, instalam-se os primeiros estabelecimento industriais, como a fábrica de chapéus Bierrembach e a fundação Faber. Em 1867, com capital derivado essencialmente de cafeicultores, fundou-se a Ferrovia Paulista que entra em operação em 1872.

Entretanto, com as epidemias de febre amarela, entre 1889 e 1893, Campinas passa por um período de forte retração e que introduziu algumas alterações significativas na estrutura da cidade. Entregues a sua própria sorte, os campineiros desenvolveram instituições como o cemitério, a Santa Casa de Misericórdia e asilos para dar conta do enorme número de mortos, doentes e órfãos da epidemia que reduziu em cerca de metade a população da cidade. Na ocasião foi apressada a construção do sistema de abastecimento, inaugurado a 2 de janeiro de 1891, pelo prefeito Antônio Álvares Lobo. No século seguinte, para atender ao novo surto de crescimento a partir da década de 20, a ampliação do sistema de abastecimento foi feita com a Companhia Campineira municipalizada, em 1923. A inauguração do novo sistema de abastecimento, com captação no Rio Atibaia, aconteceu em 1936, viabilizando o grande crescimento da cidade nas décadas de 40 a 70. Mas, na época, Campinas perdeu a oportunidade de instalação concomitante de um sistema de esgotos: A expansão sem limite dos espaços urbanos, em Campinas e região, nas décadas de 50 a 80 do século 20, foi fatal para a saúde dos rios. Segundo o historiador José Roberto do Amaral Lapa, diretor do Centro de Memória da Universidade Estadual de Campinas a crise gerada pela epidemias de febre amarela foi logo superada e a cidade voltou ao seu rítmo acelerado de crescimento, mesmo com a crise da economia cafeeira, a partir da década de 1930, a cidade "agrária" de Campinas assumiu uma fisionomia mais industrial e de serviços. No plano urbanístico, por exemplo, Campinas recebeu do "Plano Prestes Maia" (1938), um amplo conjunto de ações voltado a reordenar suas vocações urbanas, sempre na perspectivas de impulsionar velhos e novos talentos, como o de pólo tecnológico do interior do Estado de São Paulo. No mesmo percurso, a cidade passou a concentrar uma população mais significativa, constituída de migrantes e imigrantes procedentes das mais diversas regiões do estado, do País e do mundo, e que chegavam à Campinas atraídos pela instalação de um novo parque produtivo (composto de fábricas, agro-indústrias e estabelecimentos diversos). Entre as décadas de 1930 e 1940, portanto, a cidade de Campinas passou a vivenciar um novo momento 
histórico, marcado pela migração e pela multiplicação de bairros nas proximidades das fábricas, dos estabelecimentos e das grandes rodovias em implantação - Via Anhanguera, (1948), Rodovia Bandeirantes (1979) e Rodovia Santos Dumont, (década de 1980) e Rodovia D. Pedro I, (década de 1990). Na figura 25 a seguir pode-se visualizar a mancha urbana de Campinas, cortada por estas principais rodovias. Estes novos bairros, implantados originalmente sem infra-estrutura urbana, conquistaram uma melhor condição de urbanização entre as décadas de 1950 a 1990, ao mesmo tempo em que o território da cidade aumentava 15 vezes e sua população, cerca de 5 vezes. De maneira especial, entre as décadas de 1970/1980, os fluxos migratórios levaram a população a praticamente duplicar de tamanho.

Desde sua fundação, Campinas caracterizou-se por seu rápido crescimento e fonte de atração de fluxos imigratórios do exterior e do Brasil. De 1945 a 1955 a área territorial urbana de Campinas cresce em mais de 200\% e após, 1950, a população aumenta vertiginosamente a cada década. Atualmente Campinas tem uma área de $801 \mathrm{~km} 2$, com 968.172 habitantes (IBGE/Censo preliminar de 2000). O Município possui quatro distritos - Joaquim Egídio, Sousas, Barão Geraldo e Nova Aparecida - e 98,34\% da população vive em áreas urbanas. $\mathrm{Na}$ atualidade, Campinas ocupa uma área de $801 \mathrm{~km}^{2}$ e conta com uma população aproximada em 1 milhão de habitantes e é o pólo de uma região metropolitana formada por 19 cidades, (figura 26) uma população estimada em 2,33 milhões de habitantes $(6,31 \%$ da população do Estado abrigando 6,31\% da população do Estado com 2,33 milhões de habitantes. Na Tabela 2, ao final podemos ter uma visualização rápida da estrutura populacional da região., distribuída por quatro distritos (Joaquim Egídio, Sousas, Barão Geraldo, e Nova Aparecida) e centenas de bairros. 
Figura - 24. Localização do Parque Imperador na mancha urbana de Campinas

\section{Município de Campinas}

Localização do Parque Imperador

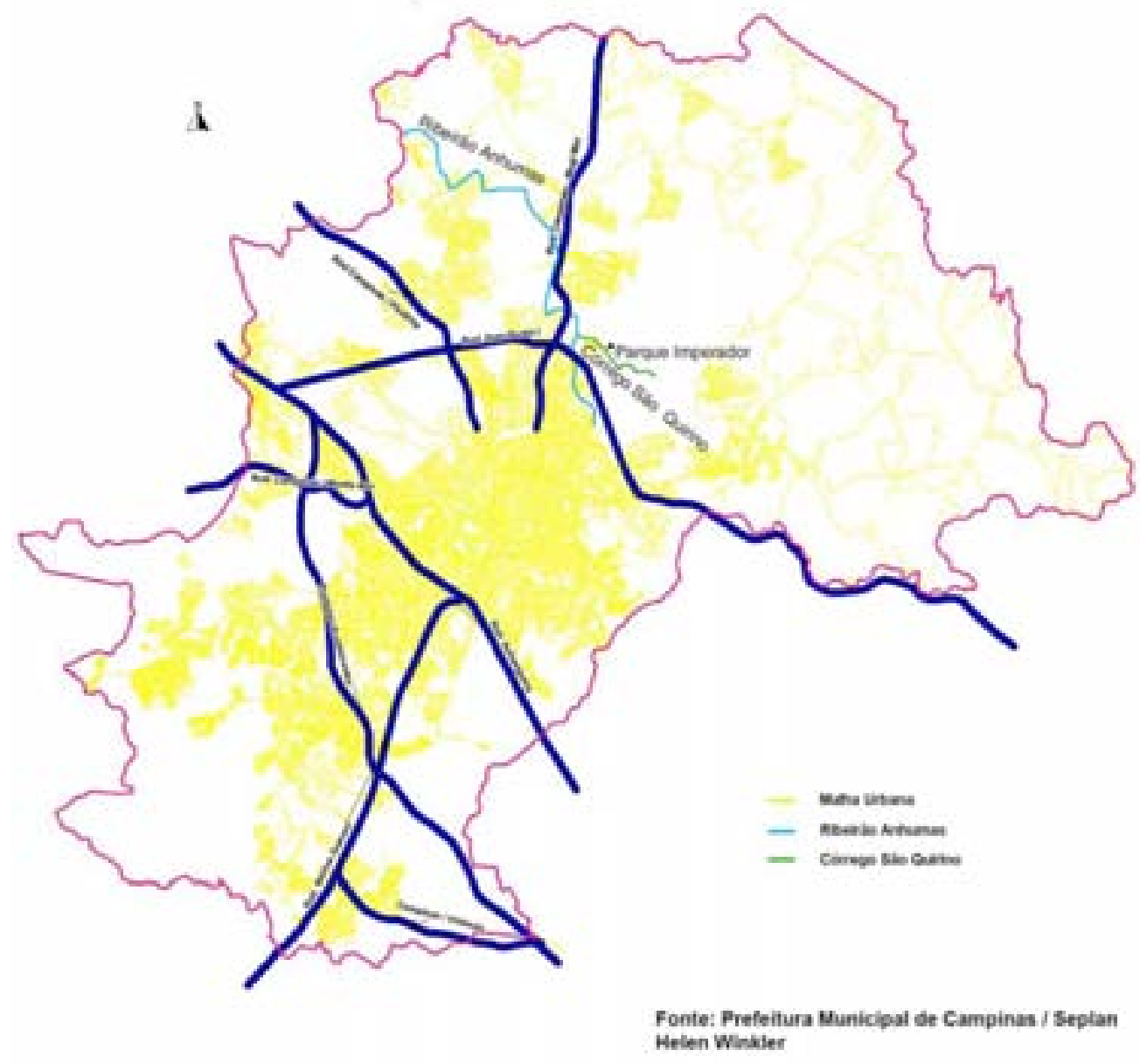


Figura 25 - Mapa ilustrativo da Região Metropolitana de Campinas.

\section{Região Metropolitana de Campinas}

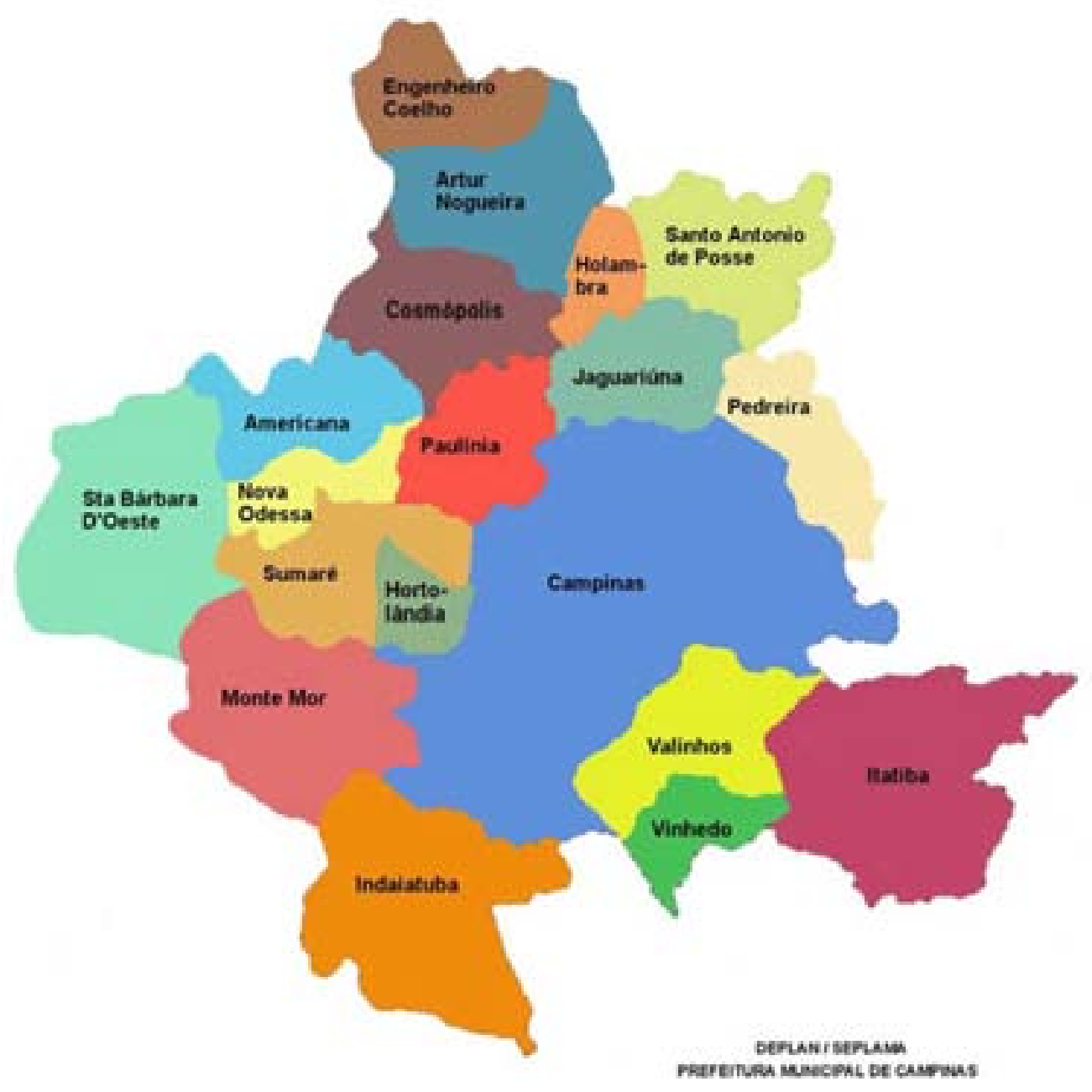


Tabela 2 - Perfil sócio-econômico da Região Metropolitana de Campinas - 2000

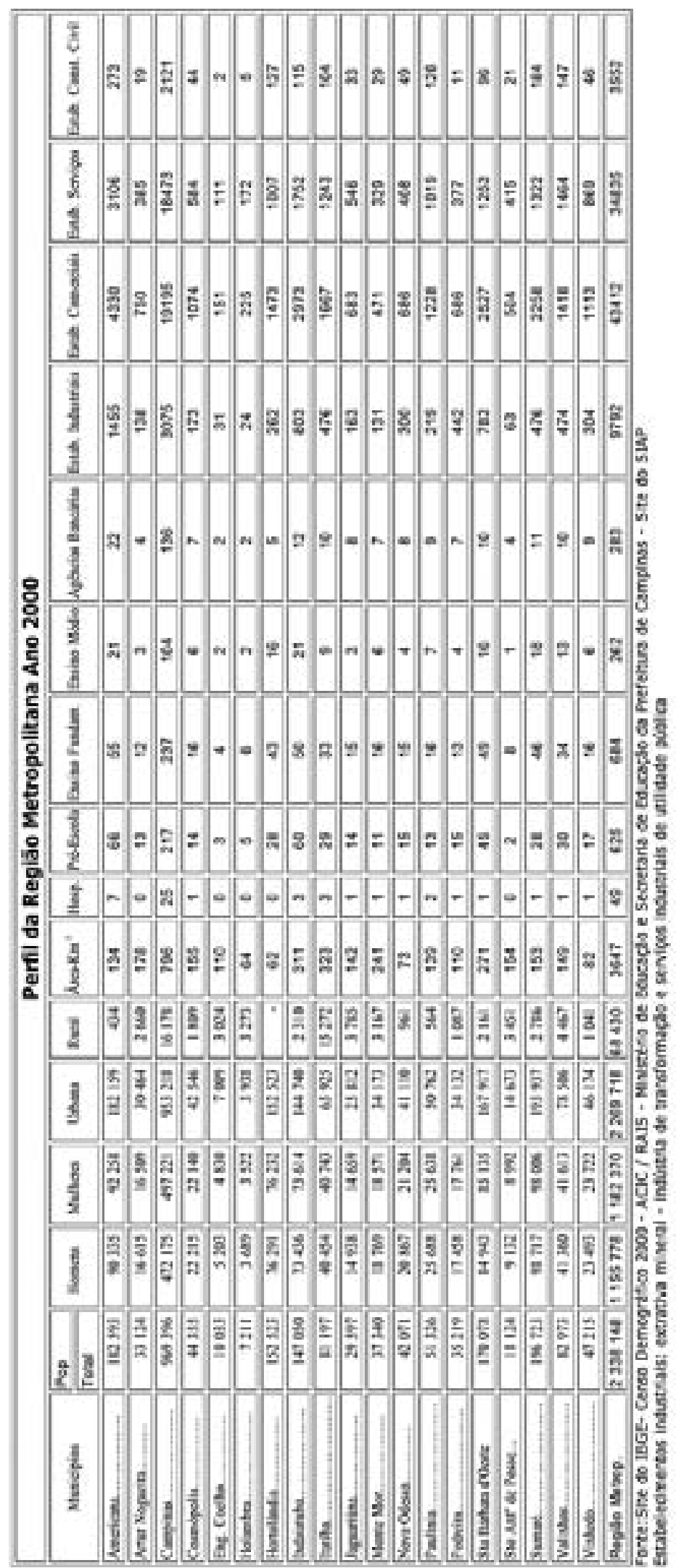




\section{REFERÊNCIAS BIBLIOGRÁFICAS}

ADORNO, T; HORKHEIMER, M. (1944) Dialética do esclarecimento. Jorge Zahar. Rio de Janeiro. 1985

AUGUSTO, L.G. da S. (2002) A construção de indicadores em saúde ambiental: desafios conceituais. In Saúde e Ambiente Sustentável: Estreitando nós. org. Minayo \& Miranda. Rio de janeiro; Editora Fiocruz 2002

FERREIRA, A B de H. (1992) Novo dicionário da língua portuguesa. Rio de Janeiro, Editora Nova fronteira. 14 a edição. 1992

BECK, U., A reinvenção da política: rumo a uma teoria da modernização reflexiva" in, Modernização Reflexiva: Política, tradição e estética na ordem social moderna . São Paulo. Editora da UNESP. 1997

BELLUCCI, S.B. BORGES, N.R., GUARABYRA, D., HEBLING, E .M. Mulheres de baixa renda e prevenção de DST/AIDS: seis anos de aprendizado. In J. Brasileiro de Doenças Sexualmente Transmissíveis. 10(4) - 09/1998

BLACKBURN, S. The Oxford dictionary of Philosophy. Oxford, Oxford University press. 1996.

BRANDÃO, C.A L. Introdução à hermenêutica da arte e da arquitetura (1) . Interpretação e arquitetura. Minas Gerais, v.3, n.6, 2003. Disponível na Internet: http://www.arq.ufmg.br/ia/introducao.html (15 abril 2004)

CAMPINAS (Município) Secretaria de Planejamento, Desenvolvimento Urbano e Meio Ambiente. Plano local de gestão urbana: região de Campo Grande. Coordenação de Adriana Barboza Rangel. Campinas, 2000. Texto disponível na Internet: http://www.pmc.sp.gov.br/seplan/campogrande/index.htm (março, 2003)

CAMPINAS (Município) Secretaria de Planejamento, Desenvolvimento Urbano e Meio Ambiente. Plano Diretor do Município de Campinas. Lei complementar oo4 de 17/01/1996. Texto disponível na Internet: http://www.campinas.sp.gov.br/bibjuri/leicomp04.htm (outubro, 2004)

CAMPINAS (Município) SANASA. Mapas de bacia do Ribeirão Anhumas. Informação disponível na Internet: www.sanasa.com.br/institucional/san_atual.asp+mapa+Campinas+rios\&hl=pt$\underline{\mathrm{BR}}(01 / 11 / 04)$

CAMPINAS. Chuva mata 4 e provoca caos em Campinas. Correio Popular. $18 \mathrm{de}$ fevereiro de 2003. p. C-4. 
CAMPINAS. Izalene pede R $\$ 10$ mil para recuperar a cidade. Correio Popular. 19 de fevereiro de 2003. p. C-8, 9, 10

CAMPINAS. Nuvens levam medo a áreas atingidas por chuva. Correio Popular. 21 fevereiro. 2003. p. C-8

CAMPINAS. Saque é a nova ameaça em áreas alagadas. Correio Popular. 20 de fevereiro de 2003. p. C- 5, 8

CAMPINAS. Temporal causou prejuízos de R $\$ 44$ milhões. Correio Popular. 22 fevereiro. 2003. p. C-6

CAMPINAS. Áreas críticas terão prioridade. Correio Popular. 18 de dezembro de 1996. p. C-6

CAORSI, C.E. Lógica, filosofia y psicoanálisis. Montevideo, Editorial Roda Viva, 1994

CARVALHO, J. M. Os bestializados: o Rio de Janeiro e a república que não foi. Rio de Janeiro, Companhia das Letras, 1987

CASTELLS, M. The City and the Grassroots: A cross-cultural theory of urban social movements. California, University of California Press. 1983.

CONFERÊNCIA DAS NAÇÕES UNIDAS SOBRE MEIO AMBIENTE E DESENVOLVIMENTO (CNUMAD). Agenda 21, Rio de Janeiro, 1992. Texto disponível na Internet http://www.mma.gov.br/

CORPUS - referencias: In dicionário na internet. Texto disponível na internet: hhttp://education.yahoo.com/reference/encyclopedia/entry?id=10159

COSTA, M. T. Contrato traz US $\$ 19,8$ milhões do Procen. Correio Popular. Campinas, 21 de dezembro de 1996. p. C-7

Justiça adia liberação de verba contra enchentes. Correio Popular. Campinas, 27 de dezembro de 1996.

DOR, J. L'A Scientificité de la psychanalyse. Paris, Editions Universitaires, 1988 .Vol. 1 e 2

FABRIANI, C. B. Planejamento Urbano: Existem perspectivas? Rio de Janeiro, 1982. Dissertação (mestrado) - Coordenação De Programas De Pós Graduação Em Engenharia, Universidade Federal do Rio de Janeiro

FABRIANI, C. B. Por uma política de conservação da natureza: o desafio de Petrópolis. Revista de Administração Pública-FGV, Rio de Janeiro, v. 25, Abr./jun. 1991.

FABRIANI, C. B. R., GARBIN, L. S, ZARONI, M. GOMES, L. M. B.. Motivos Que Influenciaram O Portador De Hiv Na Revelação De Seu Diagnóstico Aos Seus Familiares. 2000. mimeo

FARIA. Junto com as águas, vai a espera. Correio Popular. Campinas, 23 de fevereiro. De 2003. p. C-6

FIGUEIREDO, L.C. Matrizes do pensamento psicológico. Rio de Janeiro: Vozes, 1991 
FONSECA, L. Chuva deixa 83 bairros sem energia elétrica. Correio Popular. Campinas, 15 de agosto 1996. p. G-8

FREUD, S. (1900) Interpretação dos Sonhos, segunda parte. In: Edição standard brasileira de obras psicológicas completas de Sigmund Freud. Trad. sob a direção de Jayme Salomão. Rio de Janeiro, Imago, 1980. v. 5, p. 361-541

(1905) Fragmentos de analise de um caso de histeria. In: Edição standard brasileira de obras psicológicas completas de Sigmund Freud. Trad. sob a direção de Jayme Salomão. Rio de Janeiro, Imago, 1980. v.7. p.5-119

(1913 ) Totem e tabu, parte I "horror ao incesto". In: Edição standard brasileira de obras psicológicas completas de Sigmund Freud. Trad. sob a direção de Jayme Salomão. Rio de Janeiro, Imago, 1980. v. 13. P.17-190.

(1915) O Inconsciente. In: Edição standard brasileira de obras psicológicas completas de Sigmund Freud. Trad. sob a direção de Jayme Salomão. Rio de Janeiro, Imago, 1980. v. 14, p. 191 - 232.

(1925) A Negativa. In Edição standard brasileira de obras psicológicas completas de Sigmund Freud. Trad. sob a direção de Jayme Salomão. Rio de Janeiro, Imago, 1974. v. 19, p.295 - 302

(1927) O Futuro de uma Ilusão. In Edição standard brasileira de obras psicológicas completas de Sigmund Freud. Trad. sob a direção de Jayme Salomão. Rio de Janeiro, Imago, 1980. v. 21, p.15 - 71

(1939) Moisés e o monoteísmo - parte II item d "A renuncia ao instinto". In Edição standard brasileira de obras psicológicas completas de Sigmund Freud. Trad. sob a direção de Jayme Salomão. Rio de Janeiro, Imago, 1980. v. 23 , p. $30-70$

(1940) Esboço de Psicanálise, parte III. In: Edição standard brasileira de obras psicológicas completas de Sigmund Freud. Trad. sob a direção de Jayme Salomão. Rio de Janeiro, Imago, 1980 Volume 23. p 224-246

GASKELL, G. Entrevistas individuais e grupais. In Pesquisa Qualitativa com texto, imagem e som: um manual prático, Org. Bauer e Gaskell. Petrópolis, Vozes. 2002

GIDDENS, A (1991) Modernity and self-identity: Self and society in the late modern age. California, Stanford University Press, 1999

GIDDENS, A. (1991) As conseqüências da modernidade . São Paulo: Editora UNESP, 1991

IANNI, 0. Estado e Planejamento Econômico no Brasil ( 1930 - 1970) . Rio de Janeiro. Civilização Brasileira. 1971

JACOBSON, R. The internet encyclopedia . Referência obtida via base de dados: disponível na internet: http://education.yahoo.com/reference/encyclopedia/entry?id=24158 (15 abril 2004)

JAVCHELOVITCH, S. e BAUER, M. Entrevista narrativa. In Pesquisa Qualitativa com texto, imagem e som: um manual prático. Org. Bauer e Gaskell. Petrópolis, Vozes. 2002 
LASH, C. (1984) O Mínimo Eu: Sobrevivência psíquica em tempos difíceis. São Paulo, Brasiliense, 1986

LIAKOPOULOS, M. Análise argumentativa, in Pesquisa qualitativa com texto imagem e som: Um manual prático. Org. Bauer e Gaskell. Petrópolis, Vozes. 2002

LIEBER, F.R. \& ROMANO-LIEBER, N.S. O Conceito de Risco: Janus reinventado in Saúde e Ambiente Sustentável: Estreitando nós . org. Minayo \& Miranda. Rio de janeiro; Editora Fiocruz 2002

MAINGUENEAU, D. Les Termes Clés De L'analyse Du Discours. Seuil, Paris, França. 1996,

MARTINS, J. P. BID libera verba para obras de saneamento. Correio Popular. Campinas, 27 de abril de 1996.

Defesa civil antecipa plano contra enchentes. Correio Popular. Campinas, 13 de setembro de 1996. p. C-8 05 maio. 2003. P.

Dos chafarizes aos rios hoje poluídos. Correio Popular, Campinas,

MICHAELIS. Moderno Dicionário da língua portuguesa. Disponóvel na internet http://www2.uol.com.br/michaelis/. (06 de setembro de 2004)

PEARLMAN, J. The myth of marginality. Massachessets, MIT press 1974.

PIAGET, J. e GRÉCO, P. Aprendizagem e conhecimento. São Paulo, Livraria Freitas Bastos, 1974.

PRADO JUNIOR A. A Pesquisa Científica Transdisciplinar Em Informática: Situação, Fronteiras E Perspectivas" disponível na internet http://www.inf.ufpa.br/textos/texto0001.htm (07 de junho de 2004)

REI, G. Medo de nova tragédia persiste um ano depois. Correio Popular. Campinas, 15 de fevereiro. 2004. p. C-6

RODRIGUES, A. M. O padrão de distribuição de papeis em famílias operárias” In Mulheres na Força de trabalho na América Latina: Análises Qualitativas, Petrópolis, Vozes, 1984.

ROSA, E. M. Radiografia de um processo social: Um estudo sobre as relações entre direito, família, violência e crianças. São Paulo, 2003. 200p. Tese (doutorado) - Instituto de Psicologia, Universidade de São Paulo.

SANTOS, B, de s. Pela mão de Alice.: O social e o político na pós-modernidade. São Paulo, Cortez editora. 1999

SÃO PAULO. Departamento de águas e energia elétrica - DAEE. Informação sobre a outorga de uso de recursos hídricos no estado de São Paulo. Texto disponível na internet. http://www.aplicacoes.daee.sp.gov.br/usosrec/daeeusosrio.asp $(07 / 11 / 04)$

SEMINÁRIO INTERNACIONAL DE EDUCAÇÃO E CULTURA São Paulo, 2002. Referências sobre o pensamento de Edgar Morin. Disponível na Internet: http://hps.infolink.com.br/peco/main.htm 
TASSARA, E.T.O Globalização, paradigmas e utopias: questões de método na pesquisa social contemporânea. In ANPEPP, São Paulo, 1996. Coletâneas, Vol. I número 13, setembro de 1996

e Rabinovich, E. A invenção do urbano e o poético: uma cartografia afetiva - estudo sobre o bairro paulistano da Barra Funda. In: Tassara, E.T.O., ed. Panoramas interdisciplinares. Para uma psicologia ambiental do urbano. São Paulo, EDUC/FAPESP/CAPES, 2001 p.211 - 267.

Relatório de projeto " Avaliação de processos participativos em programas de educação ambiental. Subsídios para o delineamento de políticas públicas FAPESP - processo 98/15507-1, outubro de 2001.

Psicologia Ambiental E Futuro - Reflexões Geopolíticas Sobre Política Ambiental. Trabalho apresentado no Simpósio internacional : "O papel da psicologia ambiental no estudo das questões ambientais". LAPSI-IAPS. São Paulo, 2002.

\& ARDANS, O . Participação emancipatória: reflexões sobre a mudança social na complexidade contemporânea. Revista Imaginário $n .^{\circ} 9$ NIME - LABI. Instituto de Psicologia, Universidade de São Paulo . 2003

VASCONCELOS, J. Senado autoriza empréstimo para Campinas. Correio Popular. Campinas, 18 de dezembro de 1996.

VELOSO. C . Sampa. http://caetano-veloso.cifras.art.br/cifra_413.html 